\title{
Variability of plant heat shock factors: regulation, interactions and functions.
}

\author{
Norbert Andrási ${ }^{1}$, Aladár Pettkó-Szandtner ${ }^{1}$, and Laszlo Szabados ${ }^{1}$ \\ ${ }^{1}$ Biological Research Centre
}

July 20, 2020

\begin{abstract}
In plants Heat Shock Factors (HSFs) are encoded by large gene families and are primary regulators of responses not only to high temperatures but also to a number of other abiotic stresses and pathogen threats. Here we provide an overview of the diverse world of the plant HSFs through analysis of their functional versatility, regulation and interactions. HSFs can regulate tolerance to a number of extreme conditions including high or low temperatures, drought, hypoxic conditions, soil salinity, toxic minerals, strong irradiation or pathogen defenses. Variability is reflected in expression control with considerable differences in transcript profiles of individual HSF genes. Moreover, alternative splicing and posttranslational modifications provides further variability. HSFs are involved in complex web of protein-protein interactions which include formation of homomeric and heteromeric HSF trimers, and complexes with a number of other regulatory proteins including transcription regulators, chromatin-associated proteins or heat shock proteins (HSPs). Interactions of the Arabidopsis HSFA4A with proteins which control transcription, cellular homeostasis, responses to different stresses and programmed cell death, illustrate the complexity of the regulatory networks related to a plant HSF. Diversity in plant HSFs facilitates the adaptation to multiple adverse environmental conditions, an important feature in response to climate change.
\end{abstract}

\section{INTRODUCTION}

Heat shock factors (HSFs) have been identified as transcriptional regulators of genes encoding heat shock proteins (HSPs), molecular chaperons that protect cells from damage during high temperatures and maintain protein homeostasis (Boston, Viitanen \& Vierling, 1996). While yeast and Drosophila have a single HSF and mammalian cells live with four HSFs, in plants large gene families with 18 to 52 members encode HSFs, which are divided into A, B and C classes (Guo, Liu, Ma, Luo, Gong \& Lu, 2016, Sakurai \& Enoki, 2010, Scharf, Berberich, Ebersberger \& Nover, 2012). The Heatster database (http://www.cibiv.at/services/hsf/) currently contains 848 HSF sequences from 33 plant species, with an average of 25.7 HSFs in a plant genome.

HSFs have a modular structure with various well conserved domains. Their DNA binding domain (DBD) is located close to the N-terminus of the protein, which recognize the heat shock element (HSE, 5'-nGAAnnTTCn3') of the target promoters (Sakurai \& Enoki, 2010, Scharf et al. , 2012, Schultheiss, Kunert, Gase, Scharf, Nover \& Ruterjans, 1996). The Oligomerisation Domain (OD or HR-A/B motif) is located next to DBD and is responsible for protein-protein interactions and trimerisation during transcriptional activation. Classification of plant HSFs into A, B and C classes is based on the features of their ODs (Nover, Scharf, Gagliardi, Vergne, Czarnecka-Verner \& Gurley, 1996). Heat shock factors are shuttling proteins, localized either in cytoplasm or nuclei, depending on the cellular conditions. The nuclear localization signal (NLS) and the nuclear export signal (NES) at the C-terminus of class A HSFs regulate nuclear import and export processes, respectively (Heerklotz, Doring, Bonzelius, Winkelhaus \& Nover, 2001). Class A HSFs possess one or more activator motifs (AHA) located close to NES at the $\mathrm{C}$ terminal region, which is needed for transcriptional activation, probably by interacting with the basal transcription complex, TATA binding protein or with TFIIB (Doring, Treuter, Kistner, Lyck, Chen \& Nover, 2000, Kotak, Port, Ganguli, Bicker \& von 
Koskull-Doring, 2004). Class B HSFs have a repressor domain in the regulatory region of the protein, the highly conserved tetrapeptide LFGV motif, which is associated with their transcriptional repressor function (Czarnecka-Verner, Pan, Salem \& Gurley, 2004). Precise function of Class C HSFs' is not yet known. In monocots this family is expanded suggesting to possess specialized functions in those species.

HSFs were shown to have multiple functions. Yeast or Drosophila HSF mutations are lethal or lead to considerable developmental abnormalities, suggesting that they control cellular mechanisms unrelated to stress responses (Jedlicka, Mortin \& Wu, 1997, Sorger \& Pelham, 1988). HSF1 in mammalian cells controls transcription of genes functioning in DNA repair, elimination of damaged proteins, control of metabolism, responses to a broad range of cellular stresses and cellular carcinogenesis (Dayalan Naidu \& Dinkova-Kostova, 2017, Kang, Kim, Lee, Gil, Cha \& Lee, 2015). Broad range of HSF functions include maintenance of protein homeostasis not only during stress but also under standard physiological conditions (Sakurai \& Enoki, 2010).

Plants have large HSF families with considerable functional diversification. Hsf mutants are not lethal but have particular phenotypes which cannot be complemented by other HSFs, with exceptions for few closely related genes. Multiplication of plant HSFs happened through gene and whole genome duplications during evolution (Wang, Shi, Chen, Ma \& Xu, 2018). Among the protein domains, DBDs are the most conserved, implying strong evolutionary pressure for functional conservation, while ODs are variable in size and sequence, suggesting that individual HSFs can interact with wide spectrum of protein partners. Diversification of oligomerisation and activation domains is associated with functional divergence of HSFs during evolution (Wanget al. , 2018). Proliferation of the HSF gene family lead to specialization of individual memers and facilitated adaptation to variable land environments. Structural features and evolution of plant HSFs have thoroughly been described in excellent reviews (Guo et al. , 2016, Scharf et al. , 2012, von Koskull-Doring, Scharf \& Nover, 2007, Wang et al. , 2018). Here we focus on their functional diversity, summarizing variation in expression, post transcriptional modifications and protein-protein interactions.

\section{FUNCTIONAL DIVERSITY OF HEAT SHOCK FACTORS IN PLANTS}

Numerous reports demonstrate that plant HSFs not only regulate heat tolerance but can control responses to many biotic and abiotic constraints (Table S1) (Driedonks, Xu, Peters, Park \& Rieu, 2015, Guoet al. , 2016, Scharf et al. , 2012, Yabuta, 2016). We have compiled publications on plant HSFs which report biological functions of the investigated factors (Table S1). Focus was made on reports which revealed biological functions different from heat stress responses.

\subsection{Regulation of responses to abiotic stresses}

HSFA1-type transcription factors (TFs) are considered as master regulator of thermotolerance, directing early transcription activation of heat-induced genes (Table S1) (Driedonks et al. , 2015, Guoet al. , 2016, Liu, Liao \& Charng, 2011, Mishra, Tripp, Winkelhaus, Tschiersch, Theres, Nover \& Scharf, 2002, Scharf et al. , 2012). In non-stress conditions HSFA1 factors are tethered to inactive cytoplasmic complexes with HSP70/90 and are released during stress conditions as HSPs are removed to attach to misfolded cytoplasmic proteins (Scharf et al. , 2012). Plants have several HSFA1 genes with partially overlapping functions, which encumbers their genetic analysis. Quadruple Arabidopsis HSFA1 knockout mutants (QK, athsfa1a,1b,1d,1e ) showed impaired thermotolerance, and displayed retarded growth and developmental defects. Reduced expression of most heat and many salt and $\mathrm{H}_{2} \mathrm{O}_{2}$-induced genes in QK mutant indicated that HSFA1 genes not only regulate heat tolerance, but control responses to other stresses also (Liu et al. , 2011). On the other hand, overexpression of HSFA1 from different species conferred tolerance to several stresses including heat (Higashi, Ohama, Ishikawa, Katori, Shimura, Kusakabe, Yamaguchi-Shinozaki, Ishida, Tanaka, Seki, Shinozaki, Sakata, Hayashi \& Taji, 2013, Lee, Hubel \& Schoffl, 1995, Mishra et al. , 2002, Shah, Shah, Ali, Munir, Khan, Iqbal, Ahmed \& Jan, 2020, Zhu, Wang, Liu, Zhou, Yan, Yang \& Shen, 2018), drought (Bechtold, Albihlal, Lawson, Fryer, Sparrow, Richard, Persad, Bowden, Hickman, Martin, Beynon, Buchanan-Wollaston, Baker, Morison, Schoff, Ott \& Mullineaux, 2013), oxidative treatments (Qian, Chen, Liu, Yang, Li \& Zhang, 2014) or heavy metals (Cai, Zhang, Xu, Qi, Li, Ahammed, Xia, Shi, Zhou, Reiter, Yu \& Zhou, 2017). HSFA1B overexpression promoted peroxide signaling and enhanced drought and heat 
tolerance in Arabidopsis and oilseed rape (Bechtold et al. , 2013). HSFA1A could diminish oxidative damage during heat, $\mathrm{pH}$ changes and peroxide treatment (Qian et al. , 2014). HSFA1 factors and NPR1, a key regulator of pathogen responses were recently reported to control cold acclimation, forming a signaling hub which integrates cold and pathogen regulatory pathways (Olate, Jimenez-Gomez, Holuigue \& Salinas, 2018). Class A HSFs control hundreds of genes genes encoding proteins in proteotoxic protection such as HSPs, signaling, redox control, different metabolical pathways such as osmolyte biosynthesis and transport (Busch, Wunderlich \& Schoff, 2005, Liu et al. , 2011). Reduced activation of most heat-induced HSF genes in QK background confirm the importance of class A1 factors in stress tolerance (Figure 3). Functional diversification of class A HSFs depends on the variation of DNA binding domain (DBD), which defines the range of target genes (El-Shershaby, Ullrich, Simm, Scharf, Schleiff \& Fragkostefanakis, 2019). Class A HSFs does not act alone. HSFA1D, together with HSFA2 and HSFA3 activated APX2 in high light conditions (Jung, Crisp, Estavillo, Cole, Hong, Mockler, Pogson \& Chory, 2013). Tomato HSFA1 promotes tolerance to several abiotic stresses, which requires HSFA2 for proper activation of target genes (Mishra et al. , 2002). SlHSfA1a can confer cadmium tolerance through activating HSP genes and increasing melatonin levels by stimulating the melatonin biosynthetic gene caffeic acid O-methyltransferase 1 (COMT1) (Caiet al. , 2017). The A1-type ZmHSF06 of maize increased tolerance to drought and high temperatures in overexpressing Arabidopsis plants by enhancing antioxidant capacity and diminishing oxidative damage (Li, 2015). HSFA1 factors are the first and decisive components in a transcriptional cascade, which transmit heat and other stress signals and is responsible to maintain cellular homeostasis in adverse conditions (Ohama, Kusakabe, Mizoi, Zhao, Kidokoro, Koizumi, Takahashi, Ishida, Yanagisawa, Shinozaki \& Yamaguchi-Shinozaki, 2016, Ohama, Sato, Shinozaki \& Yamaguchi-Shinozaki, 2017).

HSFA2 is a stress-induced TF, which controls responses to heat and several other stresses in many plants (Table S1) (Charng, Liu, Liu, Chi, Wang, Chang \& Wang, 2007, Fragkostefanakis, Simm, Paul, Bublak, Scharf \& Schleiff, 2015, Nishizawa, Yabuta, Yoshida, Maruta, Yoshimura \& Shigeoka, 2006, Scharf, Heider, Hohfeld, Lyck, Schmidt \& Nover, 1998, Schramm, Ganguli, Kiehlmann, Englich, Walch \& von KoskullDoring, 2006). Expression of HSFA2 is induced by HSFA1 factors, but they form heteroligomers also, generating superactivating complexes (Scharfet al. , 1998). Overexpression of HSFA2 in Arabidopsis could enhance tolerance to salt and osmotic stresses (Ogawa, Yamaguchi \& Nishiuchi, 2007), submergence, anoxia and oxidative conditions (Banti, Mafessoni, Loreti, Alpi \& Perata, 2010, Pucciariello, Banti \& Perata, 2012), and to simultaneous heat and oxidative stresses generated by high light and methyl viologen (Nishizawa et al. , 2006). On the other hand the hsfa2 mutant was hypersensitive to heat and oxidative stresses (Nishizawa et al. , 2006, Zhang, Li, Xing \& Gao, 2009), and had reduced acclimation capacity to anoxia (Banti et al. , 2010, Pucciariello et al. , 2012). Overexpression of HSFA2 in QK mutant could partially rescue developmental defects, heat and $\mathrm{H}_{2} \mathrm{O}_{2}$ sensitivity but not the salt and osmotic hypersensitivity, suggesting that this HSF is downstream of HSFA1 in the regulatory cascade (Liu \& Charng, 2013).

HSFA2 controls a broad spectrum of target genes, which included HSPs (eg. Hsp18.1-CI), ROS scavengers (eg. ascorbate peroxidase 2, APX2), protective metabolic enzymes (eg. galactinol synthase 1, GolS1), or apoptotic regulators (Bcl-2-associated athanogene 6, BAG6)(Fragkostefanakis et al. , 2015, Nishizawa et al. , 2006, Nishizawa-Yokoi, Yoshida, Yabuta \& Shigeoka, 2009, Schrammet al. , 2006). Function of HSFA2 is conserved among species, as OsHSFA2e from rice could enhance salinity tolerance and induce stressassociated genes in transgenic Arabidopsis (Yokotani, Ichikawa, Kondou, Matsui, Hirochika, Iwabuchi \& Oda, 2008). GmHSF-34 is a heat and drought-induced A2-type HSF of soybean which improved germination and root growth in transgenic Arabidopsis in high osmotic conditions ( $\mathrm{Li}, \mathrm{Yu}, \mathrm{He}$, Chen, Zhou, Chai, Xu \& Ma, 2014). ZmHSF04 and ZmHSFA05 of maize and CtHsfA2b from African bermudagrass enhanced heat and salt tolerance of transgenic Arabidopsis plants, and could complement theathsfa2 Arabidopsis mutant (Jiang, 2018, Li, Zhang, Shao, Wang, Zhang, Zhang, Zhao, Guo \& Sheteiwy, 2019, Wang, Huang, Yang, Liu \& Huang, 2016). These results demonstrate that HSFA2 is an important and versatile stress factor in different plant species. HSFA2 was described to extend thermotolerance as it was transiently associated with promoters of genes associated with heat stress memory (Charng et al. , 2007). HSFA2-controlled stress memory relies on epigenetic regulation and involves histone methylation of target promoters (Lamke, 
Brzezinka, Altmann \& Baurle, 2016).

HSFA3 regulates basal thermotolerance and drought and salinity responses (Table S1). Overexpression of the Arabidopsis HSFA3 induced many HSP and chaperon genes and enhanced thermotolerance (Prandl, Hinderhofer, Eggers-Schumacher \& Schoff, 1998, Yoshida, Sakuma, Todaka, Maruyama, Qin, Mizoi, Kidokoro, Fujita, Shinozaki \& Yamaguchi-Shinozaki, 2008). Ectopic expression of rice OsHSFA3 could also enhance drought tolerance in Arabidopsis by increasing ABA and polyamine contents and reducing ROS levels (Zhu, Zhang, Gao, Zhou, Tang, Zhou \& Lv, 2020). Drought and heat induction of HSFA3 is controlled by the AP2type DREB2A or DREB2C TFs, showing that heat and osmotic signaling is connected (Chen, Hwang, Lim, Kim, Lee \& Lim, 2010, Schramm, Larkindale, Kiehlmann, Ganguli, Englich, Vierling \& von Koskull-Doring, 2008, Yoshida et al. , 2008). HSFA3 from other plants may have different functions. Constitutive expression of HSFA3 from tomato or lily (Lilium longiflorum ) conferred thermotolerance to Arabidopsis plants, but lead to salt hypersensitivity (Li, Zhang, Wang, Xu \& Li, 2013, Wu, Liang, Wang, Zhao, Zhong, Cao, Li, He \& Yi, 2018). Increased salt sensitivity of LiHSFA3 overexpressing plants maybe due to compromised proline accumulation by activation of the catabolic pathway (Wu et al. , 2018).

HSFA 4 -type factors control responses to various types of stresses such as desiccation, high light, salt, heavy metals and oxidative stresses in several plant species (Table S1). HSFA4A overexpression in Arabidopsis enhanced tolerance to salt, cadmium, oxidative stress generated by paraquat, anoxia and to combination of salt and heat stresses by reducing ROS accumulation and oxidative damage (Figure 1) (Andrasi, Rigo, Zsigmond, Perez-Salamo, Papdi, Klement, Pettko-Szandtner, Baba, Ayaydin, Dasari, Cseplo \& Szabados, 2019, Farago, Sass, Valkai, Andrasi \& Szabados, 2018, Perez-Salamo, Papdi, Rigo, Zsigmond, Vilela, Lumbreras, Nagy, Horvath, Domoki, Darula, Medzihradszky, Bogre, Koncz \& Szabados, 2014). On the other hand thehsfa 4 a Arabidopsis mutant was found to be hypersensitive to salinity, cadmium and oxidative stress, but not to heat (Farago et al. , 2018, Perez-Salamo et al. , 2014). Stress tolerance was associated by upregulation of genes encoding HSPs, defense-related proteins, enzymes in ROS scavenging and metabolic response or defense-related TFs such as ZAT12 or WRKY30 by directly binding to their promoters (Andrasi et al. , 2019, Davletova, Rizhsky, Liang, Shengqiang, Oliver, Coutu, Shulaev, Schlauch \& Mittler, 2005, Perez-Salamo et al. , 2014). HSFA5 was found to be repressor of HSFA4A forming heterooligomers and fine tuning HSFA4A action in ROS signalling and cell death (Baniwal, Chan, Scharf \& Nover, 2007). A4 class HSFs from other plants can also regulate responses to various stress conditions. Enhanced salt tolerance of CmHSFA4A overexpressing chrysanthemum plants correlated with activation of key ion transporters (SOS1, HKT2) and ROS scavenger enzymes (SOD, APX, CAT) (Li, Zhang, Zhao, Gao, Song, Jiang, Chen \& Chen, 2018). BnHSFA4A from oilseed rape increased desiccation tolerance of transgenic Arabidopsis seeds and rescued sensitivity of athsfa $4 a$ seeds by inducing the galactinol synthase genes GolS1 and GolS2 , responsible for biosynthesis of raffinose type osmoprotectant oligosaccharides (Lang, Liu, Xue, Li \& Wang, 2017). The cadmium-induced TaHSFA 4 A and OsHSFA $4 A$ from wheat and rice conferred $\mathrm{Cd}$ tolerance to yeast and to rice by enhancing metallothionein (MT) expression (Shim, Hwang, Lee, Lee, Choi, An, Martinoia \& Lee, 2009). PvHSFA4A from Paspalum vaginatum enhanced Cd tolerance in yeast (Chen, Chen, Tan, Liu, Zhuang, Yang \& Huang, 2016), while SaHSFA4C from the metal accumulatingSedum alfredii complemented Cd hypersensitivity of theathsfa 4 c mutant by inducing ROS-scavenging enzymes (Chen, Yu, Li, Wang, Lu, Zhang, Liu, Qiao, Wu, Han \& Zhuo, 2020). These data suggest, that HSFA4 factors functions as a hub to transmit ROS signals of abiotic and biotic stimuli and regulate cellular homeostasis through transcriptional control of protective and defense-related genes (Figure 5).

The drought and salt-induced HSFA6A and HSFA6B factors enhanced salt and drought tolerance in overexpressing Arabidopsis plants (Huang, Niu, Yang \& Jinn, 2016, Hwang, Kim, Woo, Jeong, Son, Akhter, Choi \& Bahk, 2014). HSFA6A increased ABA hypersensitivity and activated many ABA-responsive genes (Hwang et al. ,2014). HSFA6B inducedDREB2A by binding to its promoter and upregulated a set of stress and ABA-induced genes (Huang et al. , 2016). Among other species, TaHSFA6F improved thermotolerance of wheat through enhanced expression of HSP and chaperon genes (Xue, Drenth \& McIntyre, 2015), and drought and salt tolerance of Arabidopsis by increasing ABA sensitivity and upregulating many ABA or stress-induced genes (Bi, Zhao, Li \& Liu, 2020). HSFA7B could transactivate many target by binding to 
E-box promoter motifs leading to enhanced salt tolerance through stabilized ion homeostasis, reduced ROS accumulation and adjustment of osmotic potential (Zang, Wang, Zhang, Liu \& Wang, 2019).

HSFA9 is a seed specific TF in several plants. Arabidopsis HSFA9 is regulated by ABI3, the seed specific TF which controls late embryogenesis and seed desiccation. Expression of HSFA9 is compromised in the abi3 mutant, while ABI3 overexpression enhanced HSFA9 expression, which controls several HSP genes contributing to cellular protection during seed maturation (Kotak, Vierling, Baumlein \& von Koskull-Doring, 2007). HaHSFA9 in sunflower regulates tolerance to high temperatures, dehydration and ageing of seeds and embryos (Almoguera, Rojas, Diaz-Martin, Prieto-Dapena, Carranco \& Jordano, 2002, Personat, TejedorCano, Prieto-Dapena, Almoguera \& Jordano, 2014, Prieto-Dapena, Castano, Almoguera \& Jordano, 2008, Tejedor-Cano, Prieto-Dapena, Almoguera, Carranco, Hiratsu, Ohme-Takagi \& Jordano, 2010). Transcription of HaHSFA9 was induced by HaDREB2, an AP2-type TFs which controls gene expression in response to dehydration (Almoguera, Prieto-Dapena, Diaz-Martin, Espinosa, Carranco \& Jordano, 2009). Together with HaHSFA4a, overexpression of HaHSFA9 enhanced seed longevity and improved dehydration tolerance in tobacco seeds by enhancing the expression of HSP-coding genes (Personat et al. , 2014, Prieto-Dapena, Castano, Almoguera \& Jordano, 2006, Tejedor-Canoet al. , 2010). HaHSFA9 was also shown to promote photomorphogenesis, enhance blue light signaling and promote transcription of PHY and CRY target genes (Almoguera, Prieto-Dapena, Carranco, Ruiz \& Jordano, 2020, Prieto-Dapena, Almoguera, Personat, Merchan \& Jordano, 2017). Constitutive overexpression of HaHSFA9 could confer tolerance to dehydration, heat and oxidative stresses of transgenic tobacco plants and protect the photosynthetic apparatus from oxidative damage (Almoguera, Prieto-Dapena, Personat, Tejedor-Cano, Lindahl, Diaz-Espejo \& Jordano, 2012). These results suggest that HSFA9 is a key regulator of late embryogenesis and is important for desiccation tolerance of drying seeds.

HSFB -type factors are considered as transcriptional repressors or weak activators which modulate the action of class A HSFs. HSFB1 was shown to bind to HSFA2 promoter connecting upstream stimuli to downstream targets (Ikeda, Mitsuda \& Ohme-Takagi, 2011). Arabidopsis HSFB1 together with HSFA2 is implicated in the transcriptional control of wound responses (Ikeuchi, Shibata, Rymen, Iwase, Bagman, Watt, Coleman, Favero, Takahashi, Ahnert, Brady \& Sugimoto, 2018). The Arabidopsis HSFB2B functions as an integrator of circadian clock with abiotic stress signals which binds to the promoter of Pseudo Response Regulator 7 (PRR7), repressing its transcription leading to hypocotyl elongation and late flowering. HSFB2B regulates the circadian rhythm during moderate salt and heat stress (Kolmos, Chow, Pruneda-Paz \& Kay, 2014). HSFB1 from wild tomato (Lycopersicon peruvianum ) could act as co-activator of class A HSFs and contribute to maintain expression of housekeeping genes during stress (Bharti, Von Koskull-Doring, Bharti, Kumar, Tintschl-Korbitzer, Treuter \& Nover, 2004). Repressor and activator functions were attributed to the stress-induced SlHSFB1 of tomato, which was shown to enhance stress recovery (Roth, Mirus, Bublak, Scharf \& Schleiff, 2017). Ectopic expression of the stress-induced CarHSFB2 of chickpea lead to enhanced tolerance to high temperatures and drought in Arabidopsis by upregulating a number of stress induced genes (Ma, 2015). The B-type, stress-induced VpHsf1 from chinese wild grapevine enhanced acquired thermotolerance of overexpressing tobacco, while basal thermotolerance, osmotic stress tolerance and pathogen resistance was reduced (Peng S., 2013).

Other HSF genes includes the salt-induced PeHSF from the desert poplar (Populus euphratica), which binds to the HSE elements of PeWRKY1 promoter, and promotes its salt induction. Overexpression of PeWRKY1 in tobacco improved salt tolerance, suggesting that PeHSF-PeWRKY1 module is important to determine the extremophile character of P. euphratica (Shen, Yao, Sun, Chang, Wang, Ding, Qian, Zhang, Zhao, Sa, Hou, Lang, Wang, Zhao, Shen \& Chen, 2015). AtREN1 in Arabidopsis has high similarity with HSFA5 but regulates pollen development. The atren1 mutant has abnormal early pollen maturation, reduced pollen germination which is hypersensitive to high temperatures. AtREN1 was shown to be targeted to nucleolus, suggesting that it is implicated in rRNA biosynthesis (Renak, Gibalova, Solcova \& Honys, 2014).

2.2 Defense responses to pathogens and pests

Plants defend themselves against pathogenic microbes by a sophisticated immune system to detect the 
presence of bacterial effector proteins and activate the defense response. Oxidative burst by sudden ROS generation and SA propagate signals to induce defense-related genes, promote hypersensitive response (HR) and acquire certain degree of resistance (Chisholm, Coaker, Day \& Staskawicz, 2006, Kim, Kim, Kim, Mackey \& Lee, 2008). Several reports suggest that different HSFs can take part in pathogen defenses by transmitting ROS signals, promoting HR and activating defense-related genes.

The Arabidopsis HSFA1B enhanced resistance to Pseudomonas bacteria when overexpressed in transgenic Arabidopsis or rapeseed plants, while the Arabidopsis $h s f a 1 a, a 1 b$ mutant was found to be hypersensitive to this pathogen (Bechtold et al. , 2013). Transcript profiling revealed that a number of pathogen-induced genes were upregulated in HSFA4A overexpressing plants, including $W R K Y 30$, a key regulator of pathogen defenses (Perez-Salamoet al. , 2014). The Arabidopsis HSFB1 and HSFB2Bgenes control both biotic and abiotic stress responses through interference with class A HSFs. The hsfb1,hsfb2b double knockout mutant displayed higher resistance to Alternaria brassinicolafungus and upregulation of defensin genes such as the Pdf1.2(Kumar, Busch, Birke, Kemmerling, Nurnberger \& Schoffl, 2009). Enhanced binding of Class A HSFs on target defensin promoters was observed in the mutant, revealing direct interference of these HSFBs with HSFA factors. Interestingly, the same HSFB1 and HSFB2B genes repressed the heat-induced HSFs in non-stress conditions but were necessary to sustain expression of HSPs in stress conditions (Ikeda et al. , 2011).

HSFs from other plants can contribute to pathogen resistance also. Thesply mutation in rice disrupts the OsHSFA $4 A$ gene leading to heat and UV light-induced cell necrosis and susceptibility to certain pathogens (Yamanouchi, Yano, Lin, Ashikari \& Yamada, 2002). Together with the elicitor-induced CIGR2 gene, OsHSF23 is required to initiate HR in rice, in response to avirulent strains of rice blast fungus. Silencing of OsHSF23 resulted in enhanced proliferation of the pathogen (Tanabe, Onodera, Hara, Ishii-Minami, Day, Fujisawa, Hagio, Toki, Shibuya, Nishizawa \& Minami, 2016). The MeHSF3 of cassava belongs to class A HSFs which responds to Xanthomonas infection. VIGS-mediated silencing of MeHSF3 resulted in disease hypersensitivity and reduced expression of Enhanced Disease Susceptibility 1 (EDS1) and Pathogen-Related gene 4 (PR4), which turned to be direct targets of MeHSF3 (Wei, Liu, Chang, He \& Shi, 2018). MeHSFA2A, MeHSFA6A, MeHSFA9B and MeHSFB3A from cassava were recently shown to respond to diseases such as cassava bacterial blight, cassava brown streak disease, and mealybugs, suggesting that various HSFs are implicated in disease resistance in this plant (Yu, Yao, Hong, Hou, Li, Xia, Geng \& Chen, 2019). Nematode infection of resistant tomato roots leads to ROS burts and activation of HSFA-type genes leading to HR. In tomato SIHSFA1a was found to be essential for apoplastic $\mathrm{H}_{2} \mathrm{O}_{2}$ burst during nematode infection, promoting HSP90 accumulation and basal defense via HR (Zhou, Xu, Cao, Yin, Xia, Shi, Zhou \& Yu, 2018). These results demonstrate, that several class A and class B HSFs can regulate resistance to various pathogens in different plant species, mainly by coordinating and enhancing ROS signals which is essential for HR and disease resistance.

\subsection{HSFs involved in epigenetic regulation}

While HSFs are essential in stress responses, their role in epigenetic regulation is not well known. Association of several HSFs with stress memory has been described more than a decade ago (Charng et al. , 2007). More recent data revealed, that such stress memory relies on epigenetic regulation, involves micro RNAs and modulation of histone methylation of target promoters (Stief, Brzezinka, Lamke \& Baurle, 2014). HSFA2 was found to promote H3K4 di- and tri-methylation and K9ac methylation which was necessary for hyper-induction after repeated HS exposures (Lamke et al. , 2016). HSFA1 factors could also influence the HSFA2-dependent epigenetic regulation of stress memory, which facilitated the fast transcriptional activation of target genes (Liu, Lamke, Lin, Hung, Liu, Charng \& Baurle, 2018). HSFA1 factors mediate temperature-dependent chromatin rearrangement, by removal of H2A.Z nucleosomes from target genes, triggering their large-scale activation (Cortijo, Charoensawan, Brestovitsky, Buning, Ravarani, Rhodes, van Noort, Jaeger \& Wigge, 2017). In high temperatures HSFA2 induced the histone demethylase RELATIVE OF EARLY FLOWERING 6 (REF6) and the chromatin remodeling factor BRAHMA (BRM), which subsequently derepressed HSFA2. The HSFA2-REF6 module reduced tasiRNA biogenesis which enhanced the 
HEAT-INDUCED TAS1 TARGET 5 (HTT5), a nuclear protein responsible for regulation of early flowering and pathogen immunity. Interestingly, the HSFA2-REF6 loop generated heritable epigenetic changes modulating flowering and pathogen responses in progenies of heat-stressed plants (Liu, Feng, Gu, Deng, Qiu, Li, Zhang, Wang, Deng, Wang, He, Baurle, Li, Cao \& He, 2019b). These results confirm that HSFA2 is an essential regulator of heat-induced stress memory through establishing epigenetic marks on target genes which can facilitate enhanced stress response as well as modulation of developmental and defense responses.

\section{REGULATION OF PLANT HSF GENES}

Part of the functional divergence of plant HSF genes relies on variation in their regulation, which includes transcription control, post transcriptional and post translational modifications. Comprehensive expression profiling of HSF genes in a number of plant species revealed great variability during development and in response to a number of abiotic and biotic stresses. Diversity in HSF transcription was reported for Arabidopsis (Miller \& Mittler, 2006, Swindell, Huebner \& Weber, 2007), rice (Chauhan, Khurana, Agarwal \& Khurana, 2011, Yang, Wang, Gao, Zhou, Zhang, Hu, Yuan, Liang \& Xu, 2014), barley (Reddy, Kavi Kishor, Seiler, Kuhlmann, Eschen-Lippold, Lee, Reddy \& Sreenivasulu, 2014), tomato (Fragkostefanakis et al. , 2015), wheat (Agarwal \& Khurana, 2019, Xue, Sadat, Drenth \& McIntyre, 2014, Ye, Yang, Hu, Liu, Li, Zhang \& Song, 2020), maize (Yang et al. , 2014, Zhang, Li, Fu, Duan, Hu \& Guo, 2020a), Brachipodium and sorghum (Nagaraju, Reddy, Kumar, Srivastava, Kishor \& Rao, 2015, Yang et al. , 2014), pepper (Guo, Lu, Zhai, Chai, Gong \& Lu, 2015), radish (Tang, Xu, Wang, Cheng, Luo, Xie, Fan \& Liu, 2019), physic nut (Zhang, Chen \& Shi, 2020b), tea (Xu, Guo, Pang, Zhang, Kong \& Liu, 2020), poplar (Liu, Hu \& Zhang, 2019a) and chinese cabbage (Huang, Li, Wang, Xu, Huang, Wang, Ma \& Xiong, 2015). For example soybean HSF genes were shown to respond diversely to drought or high temperatures. Out of the 19 genes tested, 14 genes were induced by drought, 13 genes were upregulated, 2 genes were repressed by heat and 10 soybean genes responded to both treatments (Li et al. , 2014). Meta-analysis of microarray transcript profiles of 25 rice HSF genes showed, that $19 \mathrm{HSF}$ were associated with heat stress, 11 genes with drought, 9 genes were regulated by salt and 7 genes with cold (Jin, Gho \& Jung, 2013). Such analysis pointed to diversity as well as redundancy in the HSF gene families.

Web-based databases with thousands of microarray or RNAseq experimental data are rich source for datamining, allowing the compilation of transcript profiles of Arabidopsis HSF genes. We used the Genevestigator database (https://genevestigator.com) containing datasets from 3243 Affymetrix and 691 RNAseq experiments, to retrieve microarray and RNAseq transcript data and identify differences in developmental regulation, responses to biotic or abiotic stimuli and alterations in a number of mutant backgrounds. Expression data were downloaded and the color-coded data were manually arranged to illustrate changes in transcript abundances. Transcript profiles were complemented with microarray dataset, dowloaded from Arabidopsis eFP Browser (http://bar.utoronto.ca/efp_arabidopsis/cgi-bin/efpWeb.cgi).

3.1 Developmental and genotype-dependent regulation of Arabidopsis HSF genes.

According to the Genevestigator transcript data, variability in developmental regulation of the 21 Arabidopsis HSF genes is moderate, with some notable exceptions. In most developmental stages transcript levels of HSFA1D, HSFA 4A, HSFA8, HSFB2A and HSFB4 were higher, while HSFA2, HSFA3, HSFA6A, HSFA6B and HSFB2B were lower than the average (Figure 2A). HSFA1B, HSFA1E and HSFA9 had elevated transcripts in senescent plants, suggesting that these genes are implicated in senescence control. Germination caused pronounced changes in most HSF genes. HSFA1E, HSFA $4 A$ and HSFA9 genes became suppressed, HSFA1A, HSFA1B, HSFA5, HSFA8 and HSFC1 were downregulated, while HSFA2, HSFA7A, HSFA7B, $H S F B 2 A$ and $H S F B 2 B$ were temporally upregulated during germination (Figure 2B).

Genotype-dependent variation in expression of Arabidopsis HSF genes was studied in 34 ecotypes using Arabidopsis eFP Browser datasets (Table S2). Transcript levels of HSFA1D and HSFB2A were highest and HSFA2, HSFA6A, HSFA $7 B$ and HSFB3 were lowest in the ecotypes tested. Elevated transcript levels of HSFA1D in all ecotypes suggest that this HSF is dominant in the HSFA1 subfamily. It is notable, that transcript level of HSFA2 was high in the Sha ecotype, originated from high mountains of Tajikistan, and was 
low in plants from mild continental climates including Col-0, the standard laboratory ecotype. Comparing to Col-0, transcript levels of HSFA1 genes were higher in ecotypes collected in warm climates (Table S2).

\subsection{Responses to extreme environmental conditions}

Transcript data extracted from Arabidopsis eFP Browser or Genevestigator databases revealed considerable variation of the individual HSF genes in response to different abiotic and biotic stresses. According to eFP Browser, 7 of the 21 Arabidopsis HSF genes were only weakly induced by any stress treatments, while the remaining were responsive to one or more treatments (Table S3, S4).

In Col-0 ecotype heat stress induced the expression of 7 Arabidopsis HSF genes: HSFA2, HSFA3, HSFA 7A, HSFA 7B, HSFB1, HSFB2A and HSFB2B (Figure 3, table S3). In the WS ecotypeHSFA1D and HSFA1E genes were also upregulated. HSFA1 factors are encoded by constitutively expressing genes and the proteins form inactive complexes with HSP70/90 chaperons. Upon heat stress, HSFA1s are released and activate downstream genes, including the heat-induced HSFs (Scharf et al. , 2012). Such model is consistent with transcript data, showing that activation of most heat-induced HSF genes was abolished or considerably reduced in the QK mutant, while transcript levels of HSFA6B were enhanced (Liu et al. , 2011) (Figure 3). Heat-induced activation of other TFs, such as the AP2-type DREB2A was also abolished in the QK mutant (Yoshida, Ohama, Nakajima, Kidokoro, Mizoi, Nakashima, Maruyama, Kim, Seki, Todaka, Osakabe, Sakuma, Schoffl, Shinozaki \& Yamaguchi-Shinozaki, 2011). DREB2A and DREB2C could induce HSFA3 and were needed for high level of expression during heat stress (Chen et al. , 2010, Sakuma, Maruyama, Qin, Osakabe, Shinozaki \& Yamaguchi-Shinozaki, 2006, Schramm et al. ,2008, Yoshida et al. , 2008). The NAC domain factor VASCULAR PLANT ONE-ZINC-FINGER 1 (VOZ1) was recently identified to downregulate HSFA3 expression by interacting with DREB2C and acting as transcriptional repressor (Song, Lee, Kim, Hong \& Lim, 2018). HSFA1, DREB2A, DREB2C, VOZ1 and HSFA3 form a transcriptional factor cascade, which regulates downstream HSP and other target genes. The NAC019 factor is dephosphorylated by the RCF2 phosphatase which is needed for promoter binding and activation of HSFA1b, HSFA6b, HSFA 7a, and HSFC1 genes. While the rcf2-1 and nac019 mutants are hypersensitive to heat, overexpression of RCF2 and NAC019 increases thermotolerance, suggesting that they are essential regulators of a subset of HSFs (Guan, Yue, Zeng \& Zhu, 2014). Similar to heat stress, azetidine-2-carboxylic acid (AZC), leads to the accumulation of misfolded proteins, trigger the cytosolic protein response, which derepress class A HSFs. AZC induced HSFA2, HSFA 4A, HSFA7A, HSFB2A and HSFB2B genes. Response to AZC was reduced in hsfa2, hsfa $4 a$ and hsfa $7 a$ mutants, suggesting that these HSFs regulate cytosolic protein response (Lin, Tsai, Lu, Wu \& Yeh, 2018).

Cold could enhance the expression of HSFA4A, HSFA6B, HSFA8 and HSFC1 genes, while HSFA $7 A$ was moderately downregulated (Figure 3, Table S3). Cold-induction of HSFA6B and HSFC1 was reported before (Swindell et al. , 2007). Transcript levels of these genes were inferior in the ice1 mutant, which disrupts the master regulator of cold responses Inducer of CBF Expression 1 (ICE1). ICE1 is a MYC-type TF which activates the C-repeat binding factor $\mathrm{CBF} 3$ gene, key regulator of many cold-induced genes (Chinnusamy, Ohta, Kanrar, Lee, Hong, Agarwal \& Zhu, 2003, Lee, Henderson \& Zhu, 2005). The ICE-CBF3 module seems to control expression of a subset of HSF genes in low temperatures.

Osmotic and salt stress could activate HSFA1E, HSFA2, HSFA4A, HSFA6A, HSFA6B, HSFB1, and $H S F C 1$, while HSFA 7Aand HSFB4 were suppressed (Figure 3, Table S3). Transcript profiling data confirmed earlier reports on osmotic and salt induction of HSFA 4A, HSFA6B and HSFC1 genes (Perez-Salamo et al. , 2014, Swindell et al. , 2007). Some of these HSFs were highly induced by salt in the myb44 mutant, while their expression was reduced in the 35S-MYB44 line (Figure 3). MYB44 was reported to control responses to various biotic and abiotic stresses, and overexpression could enhance tolerance to salinity (Persak \& Pitzschke, 2014). HSFA2, HSFA4A, HSFA6B, HSFC1 genes were also induced by drought and ABA treatment, while HSFA 7A was downregulated. With the exception of HSFA2, drought or ABA-dependent activation of HSF genes was abolished in thesrk2dei triple mutant, in which key ABA signaling SnRK2 genes are disrupted (Figure 3) (Fujii \& Zhu, 2009, Umezawa, Sugiyama, Takahashi, Anderson, Ishihama, Peck \& Shinozaki, 2013). Salt-induced expression of HSFA6B was reported to be impaired in an ABA deficient mu- 
tant, while the ABF2 TF could activate $H S F A 6 B$ through binding to its ABRE cis regulatory elements. On the other hand, HSFA6B could bind to the promoter of DREB2A and enhance its expression (Huang et al. , 2016). These results suggest that a subset of Arabidopsis HSFs are controlled by ABA-dependent signals and MYB, DREB and ABF-type TFs during drought and salinity. Such stresses were shown to induce different HSF genes in other plants such as sorghum (Nagaraju et al. , 2015) wheat (Agarwal \& Khurana, 2019, Xue et al. , 2014), or rice in which OsHSFA2 responded strongly to heat, OsHSFA3 was stimulated mostly by cold and drought (Chauhan et al. , 2011). In pepper salt or osmotic stress induced 6 or 9 HSF genes, respectively, while three genes were upregulated by both stresses (Guo et al. , 2015). In tomato several HSFs were induced by many stresses and HSFA2 defined as key regulator of stress responses (Fragkostefanakis et al. , 2015). Genome-wide transcript analysis of physic nut (Jatropha curcas L.) revealed that six and twelve HSF genes can be induced by salt and drought stress, respectively (Zhang et al. , 2020b). In the resurrection plant Haberlea rhodopensis several HSFs were highly induced during desiccation, suggesting that they are important for survival (Gechev, Benina, Obata, Tohge, Sujeeth, Minkov, Hille, Temanni, Marriott, Bergstrom, Thomas-Oates, Antonio, Mueller-Roeber, Schippers, Fernie \& Toneva, 2013).

Other stresses could enhance HSF genes in a variable pattern. Hypoxia lead to widespread alterations in HSF transcript profiles in Arabidopsis. Fast induction of HSFA4A, HSFA8 and HSFB2Awas followed by upregulation of HSFA2, HSFA3, HSFB1, HSFB2A and HSFB2B , while HSFC1 was repressed in low oxygen conditions. Recovery from hypoxic conditions reversed some but not all of the transcript changes (Figure 3). Sustained darkness enhanced the expression of a number of HSF genes, indicating disrupted photosynthesis generates stress response (Figure 3). Strong light induced the same HSF genes which were induced by heat: HSFA2, HSFA3, HSFA7A, HSFA 7B, HSFB1, HSFB2A and HSFB2B with the exception of HSFC1, which was induced by excess light but repressed by heat (Figure 3). UV-B and ozone stimulated similar sets of genes: HSFA2, HSFA4A, HSFA8, HSFB1 and HSFB2B, while HSFB4 and HSFC1 were repressed (Figure 3, table S3). HSFA4A and HSFA8 were also found to be induced by UV light in shoot (Swindell et al. , 2007). Induction of HSFA2, HSFB2A, HSFB2B and repression of HSFB4 and HSFC1 were inferior in the sng1-1 mutant (Figure 3). SNG1 controls the phenylpropanoid pathway and the UV-B-dependent gene expression (Bharti \& Khurana, 1997, Kusano, Tohge, Fukushima, Kobayashi, Hayashi, Otsuki, Kondou, Goto, Kawashima, Matsuda, Niida, Matsui, Saito \& Fernie, 2011). Wounding activates HSFA2 andHSFB1 within minutes (table S3), which was also reported before (Cheong, Chang, Gupta, Wang, Zhu \& Luan, 2002, Ikeuchi et al. , 2018). Cadmium was reported to induce HSFA4A in Arabidopsis (Perez-Salamo et al. , 2014), in wheat and rice (Shim et al. , 2009), and several HSFs in switchgrass (Panicum virgatumL.) (Song, Yuan, Wen, Xie, Lou, Hu, Cai \& Xu, 2018). These data revealed that although considerable variation exist in the expression profiles of plant HSFs, HSFA2, HSFA 4A, HSFA 8 and HSFC1 respond to most abiotic stresses, suggesting that these genes are general stress regulators in Arabidopsis.

\subsection{Responses to pathogens}

Analysis of the Arabidopsis transcript profiling data revealed that a subset of HSF genes can be induced by inoculation with various pathogens (Figure 4, Table S4). Interaction of Arabidopsis with different strains of Pseudomonas syringae is probably the best characterized pathogenesis system in plants. Infection of wild type Arabidopsis withP. syringae could strongly induce HSFA2, HSFB1 genes and upregulate HSFA4A, HSFA8 , HSFB2A, HSFB2B to some extent (Figure 4, Table S4). Induction was stronger with avirulent bacteria while it did not happen when plants were inoculated with $P$. syringae hrcC- strain, deficient in the type III secretion system, which delivers pathogen virulence factors to the plant cells (Tsuda, Sato, Glazebrook, Cohen \& Katagiri, 2008). Pseudomonas-triggered HSF activation was reduced in pad4-5 and abolished in eds1-1 mutants (Figure 4). EDS1 connects the RPS4 receptor kinase-dependent recognition of bacterial effectors to plant defenses, controls singlet oxygen-triggered SA accumulation and programmed cell death (PCD) (Heidrich, Wirthmueller, Tasset, Pouzet, Deslandes \& Parker, 2011, Ochsenbein, Przybyla, Danon, Landgraf, Gobel, Imboden, Feussner \& Apel, 2006). PAD4 (Phytoalexin Deficient 4) is an important component of SA signaling which regulates disease resistance $(\mathrm{Ng}$, Seabolt, Zhang, Salimian, Watkins \& Lu, 2011, Tsuda et al. , 2008). These results suggest, that $P$. syringae infection activates a subset of HSF genes through EDS1, PAD4 and SA-dependent signals. Infection of WS ecotype by Xanthomonas 
campestris enhanced the expression ofHSFA2, HSFA4A, HSFA7A, HSFA8, HSFB1 and HSFB2B genes. Similar sets of HSF genes (HSFA 4A, HSFA 8 and HSFB1) were enhanced by infection with fungal pathogens, such as Phytophthora parasitica, Hyaloperonospora arabidopsidis, Golovinomycesorontii, Plectosphaerella cucumerina, and Botrytis cinereawhile HSFC1 was downregulated by some of these microorganisms (Figure $4)$.

Pathogens are recognized via Microbe Associated Molecular Patterns (MAMPs), such as flagellin, EF-Tu, Pep2 or chitin (Chisholm et al. , 2006). Flg22 is a 22 amino acid peptide, corresponding to a conserved fragment of flagellin, which activates many defense-related genes and triggers resistance to pathogenic bacteria (Zipfel, Robatzek, Navarro, Oakeley, Jones, Felix \& Boller, 2004). Flg22 could induce the expression of a set of HSF genes which were similarly enhanced by most pathogens: HSFA2, HSFA4A, HSFA4C, HSFA8, HSFB1, HSFB2A and HSFB2B (Figure 4, table S4). Gene activation was abolished in the dominant gai mutant. The DELLA protein Gibberellin Insensitive (GAI) is a key negative regulator of GA signaling, and was shown to modulate pathogen responses by altering JA and SA signals (Navarro, Bari, Achard, Lison, Nemri, Harberd \& Jones, 2008). Transcript data suggest that GAI-dependent signals are needed for the induction of HSF genes by Flg22.

The Elongation factor $\mathrm{Tu}(\mathrm{EF}-\mathrm{Tu})$ is an abundant bacterial protein whose elf18 epitope is recognized as MAMP by Arabidopsis promoting plant innate immunity (Zipfel, Kunze, Chinchilla, Caniard, Jones, Boller \& Felix, 2006). PEPR1 and PEPR2 are LRR receptor kinases which activate plant defenses through perception of Pep1 or Pep2 bacterial peptide ligands (Ross, Yamada, Hiruma, Yamashita-Yamada, Lu, Takano, Tsuda \& Saijo, 2014, Yamaguchi, Huffaker, Bryan, Tax \& Ryan, 2010). Response of HSF genes to EF-Tu and Pep2 was similar, as HSFA4A, HSFA8 andHSFB1 were induced, while HSFA2, HSFA 7A, HSFB2A and HSFB2B were reduced by both peptides. Pep2-dependent activation of HSFA $4 A$, HSFA8 and HSFB1 was prevented in thepepr1-1,pepr2-3 double mutant, while induction of HSFA4Aand HSFB1 by EF-Tu was abolished in the efr-1 mutant, which disrupts $E F R$, the receptor for Ef-Tu (Zipfel et al. , 2006). Interestingly, downregulation of HSFA2, HSFA 7A, HSFB2A andHSFB2B were not affected by these receptor mutations (Figure 3). When compared to wild type plants, transcript levels of pathogen-induced HSF genes were reduced in the npr1-1, sid2-1 , pad4-1 andald1-T2 mutants, while their expression was enhanced in transgenic line overexpressing RPS4 (Figure 4). NPR1 is a key regulator of basal and systemic acquired resistance to pathogens, which controls the expression of antimicrobial genes (Cao, Glazebrook, Clarke, Volko \& Dong, 1997, Fu \& Dong, 2013). SID2 is involved in salicylic acid biosynthesis, PAD4 is a SA signaling factor (Ng et al. , 2011, Tsuda et al. , 2008) and RPS4 is receptor which recognizes the bacterial effector AvrRps4 and activates defenses and PCD through EDS1 (Fu \& Dong, 2013, Heidrich et al. , 2011). Transcript data suggest that these regulatory genes control the expression of pathogen-responsive HSF genes in Arabidopsis.

\subsection{ROS signals in HSF gene regulation}

ROS generation is a characteristic cellular response to many adverse conditions, including both biotic and abiotic stresses and is essential for acquired acclimation and plant immunity (Alvarez, Pennell, Meijer, Ishikawa, Dixon \& Lamb, 1998, Kollist, Zandalinas, Sengupta, Nuhkat, Kangasjarvi \& Mittler, 2019, Mittler \& Blumwald, 2015, Suzuki, Koussevitzky, Mittler \& Miller, 2012). Transcript profiling data showed, that a number of HSF genes were induced by different conditions, chemicals and in mutants which generate oxidative stress. Besides being a strong oxidative agent, $\mathrm{H}_{2} \mathrm{O}_{2}$ is an important signaling molecule in plant cells functioning as intermediary signal of different ROS-generating conditions which induce a number of HSF genes (Choudhury, Rivero, Blumwald \& Mittler, 2017, Mittler \& Blumwald, 2015). Expression of HSFA2, HSFA4A were strongly, while HSFB2A was moderately induced by external $\mathrm{H}_{2} \mathrm{O}_{2}$ treatment (Figure 4). $\mathrm{H}_{2} \mathrm{O}_{2}$ was shown to be essential for HSF activation and induction of HSPs and ascorbate peroxidase (APX) genes during heat stress could be blocked by antioxidants (Volkov, Panchuk, Mullineaux \& Schoffl, 2006). HSFA4A was induced within hours by $\mathrm{H}_{2} \mathrm{O}_{2}$ and paraquat which generates superoxide anions (Perez-Salamo et al. , 2014). Paraquat could induce the expression of HSFA1D as well (Swindell et al. , 2007). Expression of HSFA2, HSFA3 and HSFA $4 A$ were enhanced in the catalase deficient cat2-1 mutant, with reduced $\mathrm{H}_{2} \mathrm{O}_{2}$ scavenging capacity, whileHSFA2, HSFA4A, HSFA7A, HSFA8, HSFB1, HSFB2A and 
HSFB2Bwere induced in the flu mutant, characterized by enhanced singlet oxygen accumulation and photooxidative damage (Figure 4) (op den Camp, Przybyla, Ochsenbein, Laloi, Kim, Danon, Wagner, Hideg, Gobel, Feussner, Nater \& Apel, 2003). Antimycin A blocks the mitochondrial electron transport chain and generate the highly toxic superoxide (Dinakar, Abhaypratap, Yearla, Raghavendra \& Padmasree, 2010) and upregulatedHSFA3, HSFA4A, HSFA8, HSFB1, HSFB2A genes (Figure 4). Although different gene sets are induced by superoxide, singlet oxygen and hydrogen peroxide, there is a crosstalk between these ROS pathways (Laloi, Stachowiak, Pers-Kamczyc, Warzych, Murgia \& Apel, 2007). ROS-induced HSF genes had reduced transcript levels in the stn $7-1$ and psad1-1 mutants (Figure 4). The Photosystem I subunit D-1 (PSAD1) protein is important to sustain electron flow and to prevent overreduction of plastoquinon pool (Ihnatowicz, Pesaresi, Varotto, Richly, Schneider, Jahns, Salamini \& Leister, 2004). The STN7 kinase phosphorylates photosynthetic light harvesting antenna proteins, regulates redox homeostasis, senescence and is a principal component of retrograde signaling between chloroplast and nuclei (Ihnatowicz, Pesaresi, Lohrig, Wolters, Muller \& Leister, 2008, Tikkanen, Gollan, Suorsa, Kangasjarvi \& Aro, 2012). While ROS signals can activate stress-induced HSFs, ROS scavenging genes such as APX or CAT can be direct targets of HSFs (Jung et al. , 2013, Locato, Gadaleta, De Gara \& De Pinto, 2008, Perez-Salamo et al. , 2014, Schrammet al. , 2006). ROS signaling throught HSFs has therefore a feedback regulatory mechanism by which HSFdependent antioxidants can attenuate ROS and downregulate other target stress genes (Driedonkset al. , 2015).

\subsection{Post transcriptional regulation of plant HSFs}

While transcriptional control is the dominant mechanism in HSF regulation, modulation of transcript levels by alternative splicing and nonsense-mediated decay (NMD) have also been reported in Arabidopsis (Liu, Sun, Liu, Liu, Du, Wang \& Qi, 2013, Sugio, Dreos, Aparicio \& Maule, 2009), alfalfa (He, Xie, Zou, Wang, Zhu \& Yu, 2007), in aquatic pondweed species (Amano, Iida \& Kosuge, 2012), poplar (Liu et al. , 2019a) and in tomato (Hu, Mesihovic, Jimenez-Gomez, Roth, Gebhardt, Bublak, Bovy, Scharf, Schleiff \& Fragkostefanakis, 2020). In the TAIR database single transcript is indicated for most Arabidopsis HSF genes, two transcripts for HSFA1B, HSFA1D and HSFA3, while four transcripts are annotated for HSFA2 and HSFA $4 C$ (www.arabidopsis.org). Adverse conditions can promote alternative splicing of HSFA2 generating the inactive HSFA2-II form, which is eliminated by NMD, a mechanism which degrades mRNAs with premature termination codon (Sugio et al. , 2009). In extreme high temperatures a new splice variant of HSFA2-III was formed through a cryptic intron 5' splice site (Liu et al. , 2013). Recently a novel an U5-snRNP-interacting protein, STABILIZED 1 (STA1) was identified and reported to mediate alternative splicing of HSF and HSP transcripts in high temperatures, suggesting that a specific splicing mechanism exist at such conditions (Kim, Yoo \& Cho, 2018).

Although numerous other HSF splice variants have been identified by genome and transcript sequencing in many plant species, with few exceptions their function is not known. In alfalfa alternative splicing generated five isoforms of MsHSF1, out of which one encodes the HSFA1 protein, while the others are eliminated by NMD (He et al. , 2007). The nodule specific MsHSF1 mRNA was produced by trans-splicing between different MsHSF1 alleles (He, Zou, Wang, Zhu \& Yu, 2008). In poplar at least two mRNA splice isoforms were identified for 10 class A and 4 class B PtHSFs, while one transcript was assigned to the other 16 PtHSF genes (Liu et al. , 2019a). In wild tomato species alternative splicing resulted in accumulation of HSFA2-II isoform at expense of HSFA2-I, typical to cultivated tomato. Tomato HSFA2-II lacks nuclear export signal (NES) leading to retention in nuclei and higher capacity to promote expression of target genes without the need to interact with HSFA1A (Hu et al. , 2020). Recently a nanopore transcriptome sequencing study identified two maize class A HSF genes, ZmHSF04 and ZmHSF17 which produce new splice isoforms with alternative splicing during heat shock (Zhang et al. , 2020a). These results demonstrate that NMD can control of transcript abundance and alternative splicing can enhance protein complexity and functional diversification of HSFs in plants.

3.6 Post translational modifications of HSF proteins

Post translational modifications provide an additional layer to control the activity of HSFs, and include phos- 
phorylation, acetylation or sumoylation. Phosphorylation of yeast HSF was prerequisite for the activation of target genes with atypical HSEs (Hashikawa \& Sakurai, 2004). HSF1 in animal cells is expressed in a rather constitutive manner and its activity is regulated by post translational modifications including phosphorylation at multiple serine residues which can either enhance or reduce activity (Chu, Soncin, Price, Stevenson \& Calderwood, 1996, Holmberg, Hietakangas, Mikhailov, Rantanen, Kallio, Meinander, Hellman, Morrice, MacKintosh, Morimoto, Eriksson \& Sistonen, 2001) or sumoylation on the regulatory domain which reduce DNA binding and target gene activation (Anckar, Hietakangas, Denessiouk, Thiele, Johnson \& Sistonen, 2006, Dayalan Naidu \& Dinkova-Kostova, 2017).

As plants have large HSF families, modulation of HSF activities through phosphorylation is more complex and several classes of protein kinases are implicated in such regulation. Phosphorylation of Arabidopsis HSFA1A by the cyclin-dependent CDC2a kinase reduced DNA binding capacity (Reindl, Schoffl, Schell, Koncz \& Bako, 1997), while phosphorylation by the CaM-binding protein kinase 3 (AtCBK3) enhanced transcription activation of HSP genes and increased basal thermotolerance (Liu, Gao, Li, Han, Liu, Sun \& Zhou, 2008). Several MAP kinases mediate ROS signal transduction which can phosphorylate some of the plant HSFs in stress conditions. The heat-induced HSFA3 in tomato is a substrate of a calcium-dependent MAP kinase, which regulates heat stress responses (Link, Sinha, Vashista, Hofmann, Proels, Ehness \& Roitsch, 2002). Arabidopsis MPK3, MPK4 and MPK6 mediate ROS signaling, and accelerate responses to various biotic and abiotic stresses (Bigeard \& Hirt, 2018, Rasmussen, Roux, Petersen \& Mundy, 2012, Su, Zhang, Zhang, Sun, Liu, Lukowitz, Xu \& Zhang, 2017). The Arabidopsis HSFA2 interacted with and was phosphorylated by MPK6, facilitating nuclear transfer during heat stress (Evrard, Kumar, Lecourieux, Lucks, von KoskullDoring \& Hirt, 2013). HSFA4A interacted with MPK3, MPK4 and MPK6 and was phosphorylated on Ser309, which promoted intramolecular multimerisation and transcription of target genes (Andrasi et al. , 2019, Perez-Salamoet al. , 2014). Mass spectrometry analysis of HSFA4A could identify phosphorylated amino acid residues different from MAP kinase targets, suggesting that it can be phosphorylated at multiple sites by different kinases (Andrasi et al. , 2019). Role of protein dephosphorylation in regulation of HSFs is not well known. The calcium binding protein phosphatase 7 (PP7) was shown to mediate heat shock response in Arabidopsis and contribute to upregulation of HSP genes. PP7 could interact with HSFA1A and the calmodulin CaM3 in yeast two hybrid (Y2H) system. PP7-mediated dephosphorylation of HSFA1A subsequently enhanced expression of target HSPs and promoted heat stress responses (Liu, Li, Chang, Sun, Zhou \& Li, 2007).

Although limited information is available on sumoylation of plant HSFs, several reports demonstrated that SUMO conjugation can be an important post translational modification in plants also. Arabidopsis HSFA2 could interact with SUMO1 and sumoylated on Lys315 residue which reduced its capability to activate HSP genes. SUMO1 overexpression resembled the phenotype of hsfa2 mutant with reduced expression of HSFA2 target genes and compromised capacity of acquired thermotolerance (Cohen-Peer, Schuster, Meiri, Breiman \& Avni, 2010). Different effect was reported on the seed specific HaHSFA9 of sunflower, which was sumoylated at K38, leading to enhanced activation of a target promoter and synergistic co-activation with HSFA4A (Carranco, Prieto-Dapena, Almoguera \& Jordano, 2017). The SIZ1 SUMO E3 ligase (SISIZ1) was recently shown to interact with and mediate sumoylation of SlHSFA1 in tomato promoting the induction of HSP genes and reduction of ROS accumulation in heat-stressed plants. Overexpression of SISIZ1 enhanced, while RNAi-mediated silencing reduced heat tolerance (Zhang, Wang, Lv, Liu, Wang, Ma \& Meng, 2018). These data revealed that phosphorylation and sumoylation are frequent post translational modifications of HSF proteins in plants, which can confer enhanced or reduced activity, depending on the HSF and the introduced modification.

\section{INTERACTIONS OF PLANT HSF PROTEINS}

HSFs can physically interact with a number of proteins or protein complexes. Such interactions position HSFs in regulatory networks, define their capacity for transcription initiation, regulate intracellular location, stability and degradation. Therefore mapping protein-protein interactions can provide valuable information about their regulation and function. In order to decipher HSF interactions, we compiled published exper- 
imental data from scientific papers and public databases. Altogether 221 protein-protein interactions were identified with HSF proteins including 186 interactions of Arabidopsis HSFs, and 35 interactions of in 8 other species such as cultivated and wild tomato, maize, rice, sunflower, soybean, lily, Thellungiella and Eriobotrya species (Table 1). Protein-protein interactions were demonstrated with several methods, such as yeast two hybrids, bimolecular fluorescence complementation, pull-down or affinity capture methods coupled with mass spectrometry. While most protein-protein interactions were detected with one method, in 34 cases interactions were confirmed by two or more techniques.

4.1 Homomeric and heteromeric interactions of plant HSFs.

Heat shock factors form homo and heterotrimers, which is required for binding to HSEs in the target promoters (Lee et al. , 1995, Miller \& Mittler, 2006, Peteranderl, Rabenstein, Shin, Liu, Wemmer, King \& Nelson, 1999, Scharf et al. , 2012). 10 homomeric and 26 heteromeric HSF-HSF interactions were detected in 5 plant species. HSFA1A, HSFA1B and HSFA1D interact with each other, form homo and heterotrimers in all combinations and activate common target genes (Li, Doll, Weckermann, Oecking, Berendzen \& Schoffl, 2010b, Yoshida et al. , 2011). Multiple interactions confirm that class A HSFs regulate early heat shock response in redundant way. Heteromeric interactions between early HSFA1A, HSFA1B with the late HSFA2 was also reported showing synergistic induction of certain target genes (Li, Berendzen \& Schoffl, 2010a). Arabidopsis HSFA2 interacts also with HSFA3, suggesting that they function in overlapping regulatory pathway (Li, 2017). In tomato, interaction of HSFA1 and HSFA2 was essential for nuclear transport of HSFA2, which leads to synergistic transcriptional activation (Scharf et al. , 1998). Formation of HSFA1 and HSFA2 hetero oligomers was preferred to homomers resulting in hexameric superactivator complexes (Chan-Schaminet, Baniwal, Bublak, Nover \& Scharf, 2009).

ROS sensitivity of HSFs was suggested enable these factors to function as peroxide sensors due to their capacity to form active homo or heterotrimers in response to oxidative environment, facilitating the activation of ROS-induced genes (Miller \& Mittler, 2006). Trimerisation of Arabidopsis HSFA4A was influenced by redox status which was stabilised by oxidation of conserved Cys residues and promoting Cys-Cys bonds (Perez-Salamo et al. , 2014). Phosphorylation of the conserved Ser309 residue by MAP kinases MPK3, MPK4 or MPK6 enhanced such intramolecular interactions (Andrasi et al. , 2019). Heterooligomers of HSFA4 and HSFA5 can be formed in Arabidopsis and tomato through OD of HSFA5. While HSFA4A can induce a number of stress-responsive genes, interaction with HSFA5 represses such gene activation (Baniwal et al. , 2007). The fact that similar activation/repression exist in unrelated plant species suggests functional conservation of the HSFA4/A5 module in ROS signaling. Gene activation with other class A type HSFs was not affected by HSFA5 and interaction between HSFA1A and HSFA5 could not be detected in Y2H system (Baniwal et al. , 2007). In sunflower HaHSFA4A could interact with the seed specific HaHSFA9 which caused nuclear retention of HSFA4A promoting transcriptional synergism between these HSFs (TejedorCano, Carranco, Personat, Prieto-Dapena, Almoguera, Espinosa \& Jordano, 2014).

Homomeric interactions were reported for Arabidopsis HSFB1 and HSFB2B. The conserved OD contains hydrophobic heptad repeats which are required and sufficient for homo or heteromeric trimer formation between class A and class B HSFs (Li et al. , 2010b, Peteranderl et al. , 1999). Interaction of class A and B factors can fine tune the expression of target genes. LpHSFB1 of wild tomato (Lycopersicon peruvianum ) could interact with class A factor LpHSFA1 in vivo and functioned as coactivator of target genes. LpHSFA1 and LpHSFB1 formed an enhanceosome-like ternary complex with the plant CREB binding protein (CBP) ortholog HAC1 on target promoters leading to synergistic activation. Suppression of CBP/HAC1 lead to abolishment of transcriptional activation, suggesting that such ternary complex is essential for gene induction (Bharti et al. , 2004). Oligomerisation of HSFs was observed in rice also, where homomer formation of OsHSFA2c, OsHSFA9, OsHSFB4b and heteromerisation of OsHSFA2a with OsHSFB4b, OsHSFA7 with OsHSFB4b, OsHSFB4b with OsHSFB4c and OsHSF26 could be confirmed (Mittal, Enoki, Lavania, Singh, Sakurai \& Grover, 2011, Singh, Mittal, Lavania, Agarwal, Mishra \& Grover, 2012). Multiple combinations of heteromers between class A and B HSFs can therefore be formed in plants representing refined transcriptional control of target genes. 


\subsection{Interactions with other proteins}

Besides trimerisation, HSFs can interact with a range of other proteins. The most common category of the HSF-interacting proteins were other TFs (69 interactions). Most such interactions were however detected in a high throughput $\mathrm{CrY} 2 \mathrm{H}$-seq interactome mapping of Arabidopsis and have not been validated by other methods (Trigg, Garza, MacWilliams, Nery, Bartlett, Castanon, Goubil, Feeney, O'Malley, Huang, Zhang, Galli \& Ecker, 2017). HSF-interacting TFs belong to different protein families, and include ZnF, Homeobox, MYB, TCP, VP1-B3, NAC, MADS-box, ERF, bHLH or bZIP domain protein (Table 1).

A Y2H screen revealed that HSFA3 and HSFA6A can interact with several components of the SWI/SNF chromatin remodeling complex, BRM, SWI3B and SWI3C (Efroni, Han, Kim, Wu, Steiner, Birnbaum, Hong, Eshed \& Wagner, 2013). Results suggest that some of the HSFs can be associated with the SWI/SNF complex which regulate chromatin structure and modulate DNA binding of TFs. Interaction of Arabidopsis HSFA1A with the general transcription factors TATA binding protein 1 and 2 (TBP1, TBP2) was reported during recognition of a HSE-containing promoter (Reindl \& Schoffl, 1998). In analogy to the Drosophila model (Jedlicka et al. , 1997), plant HSFA1 can facilitate binding of TBPs to TATA box through direct interaction and therefore promote transcription activation. A Class B HSF from soybean (GmHSFB1) however prevents transcription via interaction with TFIIB via the repressor domain (Czarnecka-Verner et al. , 2004).

Heat shock factor binding proteins (HSBP) are conserved small nuclear proteins, which are negative regulators of heat shock response. In animal cells HSBP1 dissociates trimeric HSF1, reduces DNA binding and activation of target genes (Satyal, Chen, Fox, Kramer \& Morimoto, 1998). Plants have one or two HSBP coding genes in their genomes. Interactions between the Arabidopsis HSBP with HSFA1A, HSFA1B and HSFA2 reduced target promoter binding and heat shock response but promoted acquired thermotolerance and was essential for seed development (Hsu, Lai \& Jinn, 2010). In maize two HSBP proteins were identified (HSBP1/EMP2 and HSBP2) which showed non-redundant interaction with several class A heat shock factors (Fu, Rogowsky, Nover \& Scanlon, 2006).

According to the activation cycle model, inactive HSFs are retained in the cytoplasm in complex with HSP70 and HSP90, which prevents HSFs from transcriptional activation. In stress conditions the complex is dissociated and HSFs are transported into the nuclei to form active trimers (Akerfelt, Morimoto \& Sistonen, 2010, Gomez-Pastor, Burchfiel \& Thiele, 2018, Scharf et al. , 2012, Zou, Guo, Guettouche, Smith \& Voellmy, 1998). 23 interactions were identified between HSP70 or HSP90 chaperons and various HSFs in several plant species (Table 1). Interaction of HSP70 with Arabidopsis HSFA1A was mediated by the activation and DNA binding domain (Kim \& Schoff, 2002). HSP90-1 and HSP90-3 could interact with several Class A HSFs of Arabidopsis and ThHSFA1D of Thellungiella salsuginea, blocking heat shock responses (Higashi et al. , 2013, Yoshida et al. , 2011). Transactivation capacity of Arabidopsis HSFA1D was reduced by interaction with HSP70 or HSP90 with took place at the temperature-dependent repression (TDR) domain. The HSFA1D/HSP70 complex dissociated in high temperatures which was promoted by HSF phosphorylation (Ohama et al. , 2016). HSFA2 could interact with HSP90-1 in vivo, supporting nuclear transport of the ROF1-HSP90-1 complex (Meiri \& Breiman, 2009). ROF1 is a peptidyl prolyl cis/trans isomerase, needed for the prolongation of thermotolerance. Tomato HSP70 interacted with and repressed the activities of HSFA1, HSFA2 and HSFB1, while DNA binding of HSFB1 was enhanced by HSP90. HSP90 regulated transcript levels of HSFA2 and promoted proteasomal degradation of HSFB1 (Hahn, Bublak, Schleiff \& Scharf, 2011). Interaction of rice cytoplasmic HSP100 (ClpB-cyt) with OsHsfB4b and OsHsfA2c factors was demonstrated in Y1H and BiFC tests (Singh et al. , 2012). Several small HSPs can also interact with plant HSFs. HSP17.4CII formed large aggregates with HSFA2 in the cytosol of tomato, which suppressed HSFA2 (Port, Tripp, Zielinski, Weber, Heerklotz, Winkelhaus, Bublak \& Scharf, 2004). These results suggest that together with HSP70 and HSP90, small HSPs can form chaperon complexes with various HSFs and function as corepressor in transcription control.

Some of the HSFs were reported to interact with other cytoplasmic proteins. HSFA1A and HSFA8 were identified by MS/MS analysis among the 14-3-3 binding proteins, suggesting that 14-3-3s may influence HSF activity or stability (Shin, Jez, Basra, Zhang \& Schachtman, 2011). Recently interaction of Arabidopsis 
HSFA1 factors was reported with NPR1, which is key regulator of SA-mediated response to plant pathogens. In low temperatures NPR1 entered the nucleus in monomers, where it bound to HSFA1-type factors facilitating the induction of a number of target genes such as HSPs, stress-associated zinc finger proteins, and HSFA2 (Olate et al. , 2018). These data revealed that HSFA1 and HSFA2 can promote cold acclimation through interaction with NPR1. While class B HSFs are not transcriptional activators, their protein-protein interactions suggest that they can influence various regulatory pathways. Y2H screen identified several HSFB1 and HSFB2B interacting proteins, including a vesicle-associated membrane family protein (WAMP) and a calmodulin-binding protein ( $\mathrm{Li}$ et al. , 2010b). The WD40 repeat TOPLESS (TPL) and TPL-related (TPR) proteins function as corepressors in transcription regulation, which does not directly bind to DNA, but enhance repressing function of other TFs. TPL/TPR corepressors were shown to recruit various HSFs, including HSFB1, HSFB2A and HSFB2B (Causier, Ashworth, Guo \& Davies, 2012). As B class HSFs are transcriptional repressors, interaction with TPL/TPR proteins might enhance their gene silencing function.

\subsection{Identification of HSFA4A interacting proteins}

The Arabidopsis HSFA4A controls salt and oxidative stress responses, but not thermotolerance (Davletova et al. , 2005, Perez-Salamoet al. , 2014). Earlier we reported interaction of HSFA4A and phosphorylation by MPK3, MPK4 and MPK6 kinases (Andrasi et al. , 2019, Perez-Salamo et al. , 2014). To identify further HSFA4A interactors, we have carried out series of coimmunoprecipitation (Co-IP) experiments with YFP-tagged HSFA4A and the immunoprecipitated proteins were identified with mass spectrometry. Results are summarised in Table 2. HSFA5 had the highest score among the immunoprecipitated proteins, which was present in all IP samples and its abundance was similar in salt-treated and control samples. Formation of heterodimers of HSFA5 and HSFA4A was already demonstrated in which HSFA5 acted as repressor of HSFA4A (Baniwal et al. , 2007). Recently HSFA4A and HSFA5 were reported to control together the sensitivity to high irradiance (Huang, 2018). HSFA4C was the other interacting HSF which could be detected in both control and salt-treated IP samples. The less-known HSFA4C is similar to HSFA4A and was implicated in gravitropic response, hormonal regulation and root development (Fortunati, Piconese, Tassone, Ferrari \& Migliaccio, 2008). Our results shows that HSFA4A can form heteromers with both HSFA5 and HSFA4C, but not with other HSFs. Other HSFA4A-interacting proteins were quite diverse and were localized either in nuclei or in cytosol. The pre-mRNA splicing factor PRP8 is a component of the U5 small nuclear ribonucleoprotein (snRNP), involved in splicing and can be induced by heat and UV-B (Deng, Lu, Wang, Gu, Sun, Kong, Liu \& Cao, 2016). The tetratricopeptide repeat (TPR) protein HOP2, functions as co-chaperon shuttling between nuclei and the cytosol, which interacts with HSP70 and HSP90 and is implicated in acquired thermotolerance and genotoxic stress (Fernandez-Bautista, Fernandez-Calvino, Munoz, Toribio, Mock \& Castellano, 2018). HOP2 may facilitate complex formation between HSFA4A and HSP70 or HSP90 proteins. The BCL-2-associated athanogene 7 (BAG7) is a plant homolog of the mammalian apoptotic regulator, which interacts with HSP70 chaperons and regulates unfolded protein response (UPR) and programmed cell death (PCD) in pathogen attacks or in abiotic stress conditions (Doukhanina, Chen, van der Zalm, Godzik, Reed \& Dickman, 2006, Williams, Kabbage, Britt \& Dickman, 2010). BAG7 is shuttling between endoplasmic reticulum (ER) and nuclei, where it can interact with TFs and is responsible for maintaining cellular homeostasis during abiotic and biotic stresses through control of protein folding $(\mathrm{Li}$, Williams \& Dickman, 2017). It is intriguing, that the closely related gene, BAG6 was identified among the stress-induced targets of HSFA2 (Nishizawa-Yokoi et al. , 2009). Interaction of BAG7 with HSFA4A may represent a link between ER-based UPR and the apoptotic functions of these regulatory proteins. The Enhanced disease resistance 3 (EDR3) protein is related to dynamins with an N-terminal GTPase domain. EDR3 was shown to control resistance to fungal diseases linking SA signaling with mitochondrial functions, PCD and was implicated in freezing tolerance (Minami, Tominaga, Furuto, Kondo, Kawamura \& Uemura, 2015, Tang, Ade, Frye \& Innes, 2006). The nuclear Reduced chloroplast coverage 1 (REC1) is a mRNA binding protein which regulates chloroplast development (Larkin, Stefano, Ruckle, Stavoe, Sinkler, Brandizzi, Malmstrom \& Osteryoung, 2016). The linker histone protein HON4 belongs to the High Mobility Group Protein A (HMGA) family, required for DNA repair and regulates responses to genotoxic agents (Charbonnel, Rymarenko, Da Ines, Benyahya, White, Butter \& Amiard, 2018). The TIM-barrel protein is 
implicated in signal transduction, but its function is unknown. Our results show, that HSFA4A interacting proteins are involved in transcriptional control, cellular homeostasis, responses to stress and pathogen attacks and programmed cell death, which have previously been associated with HSFA4A. Further characterization is needed to validate interactions and to assign precise function to their association with HSFA4A.

\section{CONCLUSIONS}

The diverse world of the heat shock factors in plants is part of a complex, multilevel regulatory system whose principal functions is to coordinate molecular responses to changing environmental conditions, biotic and abiotic stresses. HSF variability is reflected on transcriptional and post transcriptional regulation and large spectrum of protein-protein interactions. Accumulating evidence demonstrate, that plant HSFs are not only key regulators to heat stress tolerance, but control responses to a number of other abiotic and biotic stresses also. HSFs can respond very fast to changes in cellular homeostasis, in particular to ROS accumulation and alterations in redox balance. All environmental stresses generate ROS due to breakdown in photosynthetic activity, disrupted photosynthetic and mitochondrial electron transports. Pathogen infection generates oxidative burst by triggering the activity of membrane-bound NAPD oxidases. ROS accumulation is a sensitive metabolic indicator of changing homeostasis, which can induce metabolic, hormonal and transcriptional responses. HSFs seem to integrate ROS signals in multiple way. ROS signals are at least partially responsible for transcriptional activation of stress-induced HSF genes in adverse conditions. ROS, in particular $\mathrm{H}_{2} \mathrm{O}_{2}$ signals stimulate MAP kinase cascades, resulting in phosphorylation of subset of HSFs such as HSFA2 or HSFA4A. Phosphorylation can influence subsequent sumoylation or protein-protein interactions including homomeric and heteromeric trimer formation. HSFs bind to cis regulatory HSE motifs in trimer forms, therefore stability of HSF multimers can influence their capacity to activate transcription of target genes. $\mathrm{H}_{2} \mathrm{O}_{2}$ can oxidize Cys amino acid residues, promote formation of Cys-Cys bonds and therefore stabilize the active HSF trimers. HSFs induce transcription of a range of target genes which can include other transcriptional regulators, forming transcriptional cascades. Other target genes can encode protective proteins such as HSPs, chaperons, ROS scavengers, metabolic regulators or defense-related proteins. Epigenetic regulation of heat stress memory is controlled by HSFA2, which promotes histone methylation of target genes and maintains the capability of elevated response to stress. Figure 5 illustrates regulatory interactions and the transcriptional network of HSFA4A, which coordinates responses to various abiotic and biotic stimuli. Other plant HSFs are positioned in similar networks with their appropriate differences in regulation, interacting proteins and target genes.

\section{REFERENCES}

Agarwal P. \& Khurana P. (2019) Functional characterization of HSFs from wheat in response to heat and other abiotic stress conditions. Funct Integr Genomics , 19 , 497-513.

Akerfelt M., Morimoto R.I. \& Sistonen L. (2010) Heat shock factors: integrators of cell stress, development and lifespan. Nat Rev Mol Cell Biol, 11, 545-555.

Almoguera C., Prieto-Dapena P., Carranco R., Ruiz J.L. \& Jordano J. (2020) Heat Stress Factors Expressed during Seed Maturation Differentially Regulate Seed Longevity and Seedling Greening.Plants (Basel), 9 .

Almoguera C., Prieto-Dapena P., Diaz-Martin J., Espinosa J.M., Carranco R. \& Jordano J. (2009) The HaDREB2 transcription factor enhances basal thermotolerance and longevity of seeds through functional interaction with HaHSFA9. BMC Plant Biol , 9 , 75.

Almoguera C., Prieto-Dapena P., Personat J.M., Tejedor-Cano J., Lindahl M., Diaz-Espejo A. \& Jordano J. (2012) Protection of the photosynthetic apparatus from extreme dehydration and oxidative stress in seedlings of transgenic tobacco. PLoS ONE , 7, e51443.

Almoguera C., Rojas A., Diaz-Martin J., Prieto-Dapena P., Carranco R. \& Jordano J. (2002) A seed-specific heat-shock transcription factor involved in developmental regulation during embryogenesis in sunflower. $J$ Biol Chem , 277 , 43866-43872. 
Alvarez M.E., Pennell R.I., Meijer P.J., Ishikawa A., Dixon R.A. \& Lamb C. (1998) Reactive oxygen intermediates mediate a systemic signal network in the establishment of plant immunity. Cell ,92, 773-784.

Amano M., Iida S. \& Kosuge K. (2012) Comparative studies of thermotolerance: different modes of heat acclimation between tolerant and intolerant aquatic plants of the genus Potamogeton. Ann Bot, 109 , 443-452.

Anckar J., Hietakangas V., Denessiouk K., Thiele D.J., Johnson M.S. \& Sistonen L. (2006) Inhibition of DNA binding by differential sumoylation of heat shock factors. Mol Cell Biol , 26 , 955-964.

Andrasi N., Rigo G., Zsigmond L., Perez-Salamo I., Papdi C., Klement E., Pettko-Szandtner A., Baba A.I., Ayaydin F., Dasari R., Cseplo A. \& Szabados L. (2019) The mitogen-activated protein kinase 4phosphorylated heat shock factor A4A regulates responses to combined salt and heat stresses. J Exp Bot , 70 , 4903-4918.

Arabidopsis I.M.C. (2011) Evidence for network evolution in an Arabidopsis interactome map. Science, $333,601-607$.

Baniwal S.K., Chan K.Y., Scharf K.D. \& Nover L. (2007) Role of heat stress transcription factor HsfA5 as specific repressor of HsfA4.J Biol Chem , 282, 3605-3613.

Bharti K., Von Koskull-Doring P., Bharti S., Kumar P., Tintschl-Korbitzer A., Treuter E. \& Nover L. (2004) Tomato heat stress transcription factor HsfB1 represents a novel type of general transcription coactivator with a histone-like motif interacting with the plant CREB binding protein ortholog HAC1. Plant Cell ,16 , 1521-1535.

Banti V., Mafessoni F., Loreti E., Alpi A. \& Perata P. (2010) The heat-inducible transcription factor HsfA2 enhances anoxia tolerance in Arabidopsis. Plant Physiol , 152, 1471-1483.

Bartlett A., O'Malley R.C., Huang S.C., Galli M., Nery J.R., Gallavotti A. \& Ecker J.R. (2017) Mapping genome-wide transcription-factor binding sites using DAP-seq. Nat Protoc , 12 , 1659-1672.

Bechtold U., Albihlal W.S., Lawson T., Fryer M.J., Sparrow P.A., Richard F., Persad R., Bowden L., Hickman R., Martin C., Beynon J.L., Buchanan-Wollaston V., Baker N.R., Morison J.I., Schoffl F., Ott S. \& Mullineaux P.M. (2013) Arabidopsis HEAT SHOCK TRANSCRIPTION FACTORA1b overexpression enhances water productivity, resistance to drought, and infection. $J$ Exp Bot , 64, 3467-3481.

Bharti A.K. \& Khurana J.P. (1997) Mutants of Arabidopsis as tools to understand the regulation of phenylpropanoid pathway and UVB protection mechanisms. Photochem Photobiol , 65 , 765-776.

Bharti K., Von Koskull-Doring P., Bharti S., Kumar P., Tintschl-Korbitzer A., Treuter E. \& Nover L. (2004) Tomato heat stress transcription factor HsfB1 represents a novel type of general transcription coactivator with a histone-like motif interacting with the plant CREB binding protein ortholog HAC1. Plant Cell ,16 , 1521-1535.

Bi H., Zhao Y., Li H. \& Liu W. (2020) Wheat Heat Shock Factor TaHsfA6f Increases ABA Levels and Enhances Tolerance to Multiple Abiotic Stresses in Transgenic Plants. Int J Mol Sci, 21 .

Bigeard J. \& Hirt H. (2018) Nuclear Signaling of Plant MAPKs.Front Plant Sci , 9 , 469.

Boston R.S., Viitanen P.V. \& Vierling E. (1996) Molecular chaperones and protein folding in plants. Plant Mol Biol , 32, 191-222.

Busch W., Wunderlich M. \& Schoffl F. (2005) Identification of novel heat shock factor-dependent genes and biochemical pathways in Arabidopsis thaliana. Plant $J$, 41 , 1-14.

Cai S.Y., Zhang Y., Xu Y.P., Qi Z.Y., Li M.Q., Ahammed G.J., Xia X.J., Shi K., Zhou Y.H., Reiter R.J., Yu J.Q. \& Zhou J. (2017) HsfA1a upregulates melatonin biosynthesis to confer cadmium tolerance in tomato plants. J Pineal Res, 62 . 
Cao H., Glazebrook J., Clarke J.D., Volko S. \& Dong X. (1997) The Arabidopsis NPR1 gene that controls systemic acquired resistance encodes a novel protein containing ankyrin repeats. Cell , 88, 57-63.

Carranco R., Prieto-Dapena P., Almoguera C. \& Jordano J. (2017) SUMO-Dependent Synergism Involving Heat Shock Transcription Factors with Functions Linked to Seed Longevity and Desiccation Tolerance.Front Plant Sci , 8, 974 .

Causier B., Ashworth M., Guo W. \& Davies B. (2012) The TOPLESS interactome: a framework for gene repression in Arabidopsis. Plant Physiol , 158, 423-438.

Chan-Schaminet K.Y., Baniwal S.K., Bublak D., Nover L. \& Scharf K.D. (2009) Specific interaction between tomato HsfA1 and HsfA2 creates hetero-oligomeric superactivator complexes for synergistic activation of heat stress gene expression. J Biol Chem , 284, 20848-20857.

Charbonnel C., Rymarenko O., Da Ines O., Benyahya F., White C.I., Butter F. \& Amiard S. (2018) The Linker Histone GH1-HMGA1 Is Involved in Telomere Stability and DNA Damage Repair. Plant Physiol ,177, 311-327.

Charng Y.Y., Liu H.C., Liu N.Y., Chi W.T., Wang C.N., Chang S.H. \& Wang T.T. (2007) A heat-inducible transcription factor, HsfA2, is required for extension of acquired thermotolerance in Arabidopsis. Plant Physiol , 143 , 251-262.

Chauhan H., Khurana N., Agarwal P. \& Khurana P. (2011) Heat shock factors in rice (Oryza sativa L.): genome-wide expression analysis during reproductive development and abiotic stress. Mol Genet Genomics , $286,171-187$.

Chen H., Hwang J.E., Lim C.J., Kim D.Y., Lee S.Y. \& Lim C.O. (2010) Arabidopsis DREB2C functions as a transcriptional activator of HsfA3 during the heat stress response. Biochem Biophys Res Commun ,401 , 238-244.

Chen S., Yu M., Li H., Wang Y., Lu Z., Zhang Y., Liu M., Qiao G., Wu L., Han X. \& Zhuo R. (2020) SaHsfA4c From Sedum alfredii Hance Enhances Cadmium Tolerance by Regulating ROS-Scavenger Activities and Heat Shock Proteins Expression. Front Plant Sci, 11, 142.

Chen Y., Chen C., Tan Z., Liu J., Zhuang L., Yang Z. \& Huang B. (2016) Functional Identification and Characterization of Genes Cloned from Halophyte Seashore Paspalum Conferring Salinity and Cadmium Tolerance.Front Plant Sci , 7 , 102.

Cheong Y.H., Chang H.S., Gupta R., Wang X., Zhu T. \& Luan S. (2002) Transcriptional profiling reveals novel interactions between wounding, pathogen, abiotic stress, and hormonal responses in Arabidopsis.Plant Physiol , 129, 661-677.

Chinnusamy V., Ohta M., Kanrar S., Lee B.H., Hong X., Agarwal M. \& Zhu J.K. (2003) ICE1: a regulator of cold-induced transcriptome and freezing tolerance in Arabidopsis. Genes Dev, 17 , 1043-1054.

Chisholm S.T., Coaker G., Day B. \& Staskawicz B.J. (2006) Host-microbe interactions: shaping the evolution of the plant immune response.Cell , 124, 803-814.

Choudhury F.K., Rivero R.M., Blumwald E. \& Mittler R. (2017) Reactive oxygen species, abiotic stress and stress combination. Plant $J, 90,856-867$.

Chu B., Soncin F., Price B.D., Stevenson M.A. \& Calderwood S.K. (1996) Sequential phosphorylation by mitogen-activated protein kinase and glycogen synthase kinase 3 represses transcriptional activation by heat shock factor-1. J Biol Chem , 271, 30847-30857.

Cohen-Peer R., Schuster S., Meiri D., Breiman A. \& Avni A. (2010) Sumoylation of Arabidopsis heat shock factor A2 (HsfA2) modifies its activity during acquired thermotholerance. Plant Mol Biol ,74, 33-45. 
Cortijo S., Charoensawan V., Brestovitsky A., Buning R., Ravarani C., Rhodes D., van Noort J., Jaeger K.E. \& Wigge P.A. (2017) Transcriptional Regulation of the Ambient Temperature Response by H2A.Z Nucleosomes and HSF1 Transcription Factors in Arabidopsis. Mol Plant , 10 , 1258-1273.

Czarnecka-Verner E., Pan S., Salem T. \& Gurley W.B. (2004) Plant class B HSFs inhibit transcription and exhibit affinity for TFIIB and TBP.Plant Mol Biol , 56 , 57-75.

Davletova S., Rizhsky L., Liang H., Shengqiang Z., Oliver D.J., Coutu J., Shulaev V., Schlauch K. \& Mittler R. (2005) Cytosolic ascorbate peroxidase 1 is a central component of the reactive oxygen gene network of Arabidopsis. Plant Cell , 17 , 268-281.

Dayalan Naidu S. \& Dinkova-Kostova A.T. (2017) Regulation of the mammalian heat shock factor 1. FEBS $J, 284,1606-1627$.

Deng X., Lu T., Wang L., Gu L., Sun J., Kong X., Liu C. \& Cao X. (2016) Recruitment of the NineTeen Complex to the activated spliceosome requires AtPRMT5. Proc Natl Acad Sci U S A , 113, 5447-5452.

Dinakar C., Abhaypratap V., Yearla S.R., Raghavendra A.S. \& Padmasree K. (2010) Importance of ROS and antioxidant system during the beneficial interactions of mitochondrial metabolism with photosynthetic carbon assimilation. Planta, 231, 461-474.

Dong S., Lau V., Song R., Ierullo M., Esteban E., Wu Y., Sivieng T., Nahal H., Gaudinier A., Pasha A., Oughtred R., Dolinski K., Tyers M., Brady S.M., Grene R., Usadel B. \& Provart N.J. (2019) Proteomewide, Structure-Based Prediction of Protein-Protein Interactions/New Molecular Interactions Viewer. Plant Physiol , 179 , 1893-1907.

Doring P., Treuter E., Kistner C., Lyck R., Chen A. \& Nover L. (2000) The role of AHA motifs in the activator function of tomato heat stress transcription factors HsfA1 and HsfA2. Plant Cell , 12, 265-278.

Doukhanina E.V., Chen S., van der Zalm E., Godzik A., Reed J. \& Dickman M.B. (2006) Identification and functional characterization of the BAG protein family in Arabidopsis thaliana. J Biol Chem ,281, 18793-18801.

Driedonks N., Xu J., Peters J.L., Park S. \& Rieu I. (2015) Multi-Level Interactions Between Heat Shock Factors, Heat Shock Proteins, and the Redox System Regulate Acclimation to Heat. Front Plant Sci ,6 , 999.

Efroni I., Han S.K., Kim H.J., Wu M.F., Steiner E., Birnbaum K.D., Hong J.C., Eshed Y. \& Wagner D. (2013) Regulation of leaf maturation by chromatin-mediated modulation of cytokinin responses. Dev Cell ,24, 438-445.

El-Shershaby A., Ullrich S., Simm S., Scharf K.D., Schleiff E. \& Fragkostefanakis S. (2019) Functional diversification of tomato HsfA1 factors is based on DNA binding domain properties. Gene ,714, 143985.

Enoki Y. \& Sakurai H. (2011) Diversity in DNA recognition by heat shock transcription factors (HSFs) from model organisms. FEBS Lett ,585 , 1293-1298.

Evrard A., Kumar M., Lecourieux D., Lucks J., von Koskull-Doring P. \& Hirt H. (2013) Regulation of the heat stress response in Arabidopsis by MPK6-targeted phosphorylation of the heat stress factor HsfA2.PeerJ , 1, e 59 .

Farago D., Sass L., Valkai I., Andrasi N. \& Szabados L. (2018) PlantSize Offers an Affordable, Nondestructive Method to Measure Plant Size and Color in Vitro. Front Plant Sci , 9 , 219.

Fernandez-Bautista N., Fernandez-Calvino L., Munoz A., Toribio R., Mock H.P. \& Castellano M.M. (2018) HOP family plays a major role in long-term acquired thermotolerance in Arabidopsis. Plant Cell Environ , $41,1852-1869$. 
Fortunati A., Piconese S., Tassone P., Ferrari S. \& Migliaccio F. (2008) A new mutant of Arabidopsis disturbed in its roots, right-handed slanting, and gravitropism defines a gene that encodes a heat-shock factor. J Exp Bot, 59 , 1363-1374.

Fragkostefanakis S., Simm S., Paul P., Bublak D., Scharf K.D. \& Schleiff E. (2015) Chaperone network composition in Solanum lycopersicum explored by transcriptome profiling and microarray meta-analysis. Plant Cell Environ, 38 , 693-709.

Fu S., Rogowsky P., Nover L. \& Scanlon M.J. (2006) The maize heat shock factor-binding protein paralogs EMP2 and HSBP2 interact non-redundantly with specific heat shock factors. Planta, 224, 42-52.

Fu Z.Q. \& Dong X. (2013) Systemic acquired resistance: turning local infection into global defense. Annu Rev Plant Biol , 64, 839-863.

Fujii H. \& Zhu J.K. (2009) Arabidopsis mutant deficient in 3 abscisic acid-activated protein kinases reveals critical roles in growth, reproduction, and stress. Proc Natl Acad Sci U S A, 106, 8380-8385.

Gechev T.S., Benina M., Obata T., Tohge T., Sujeeth N., Minkov I., Hille J., Temanni M.R., Marriott A.S., Bergstrom E., Thomas-Oates J., Antonio C., Mueller-Roeber B., Schippers J.H., Fernie A.R. \& Toneva V. (2013) Molecular mechanisms of desiccation tolerance in the resurrection glacial relic Haberlea rhodopensis. Cell Mol Life Sci ,70, 689-709.

Gomez-Pastor R., Burchfiel E.T. \& Thiele D.J. (2018) Regulation of heat shock transcription factors and their roles in physiology and disease.Nat Rev Mol Cell Biol , 19, 4-19.

Gong B.H., Yi J., Wu J., Sui J.J., Khan M.A., Wu Z., Zhong X.H., Seng S.S., He J.N. \& Yi M.F. (2014) LlHSFA1, a novel heat stress transcription factor in lily (Lilium longiflorum), can interact with LlHSFA2 and enhance the thermotolerance of transgenic Arabidopsis thaliana. Plant Cell Reports, 33, 1519-1533.

Guan Q.M., Yue X.L., Zeng H.T. \& Zhu J.H. (2014) The Protein Phosphatase RCF2 and Its Interacting Partner NAC019 Are Critical for Heat Stress-Responsive Gene Regulation and Thermotolerance in Arabidopsis. Plant Cell , 26 , 438-453.

Guo M., Liu J.H., Ma X., Luo D.X., Gong Z.H. \& Lu M.H. (2016) The Plant Heat Stress Transcription Factors (HSFs): Structure, Regulation, and Function in Response to Abiotic Stresses. Front Plant Sci ,7 , 114.

Guo M., Lu J.P., Zhai Y.F., Chai W.G., Gong Z.H. \& Lu M.H. (2015) Genome-wide analysis, expression profile of heat shock factor gene family (CaHsfs) and characterisation of CaHsfA2 in pepper (Capsicum annuum L.). BMC Plant Biol , 15, 151.

Hahn A., Bublak D., Schleiff E. \& Scharf K.D. (2011) Crosstalk between Hsp90 and Hsp70 chaperones and heat stress transcription factors in tomato. Plant Cell , 23, 741-755.

Hashikawa N. \& Sakurai H. (2004) Phosphorylation of the yeast heat shock transcription factor is implicated in gene-specific activation dependent on the architecture of the heat shock element. Mol Cell Biol, 24 , 3648-3659.

He Z.S., Xie R., Zou H.S., Wang Y.Z., Zhu J.B. \& Yu G.Q. (2007) Structure and alternative splicing of a heat shock transcription factor gene, MsHSF1, in Medicago sativa. Biochem Biophys Res Commun ,364, 1056-1061.

He Z.S., Zou H.S., Wang Y.Z., Zhu J.B. \& Yu G.Q. (2008) Maturation of the nodule-specific transcript MsHSF1c in Medicago sativa may involve interallelic trans-splicing. Genomics , 92 , 115-121.

Heerklotz D., Doring P., Bonzelius F., Winkelhaus S. \& Nover L. (2001) The balance of nuclear import and export determines the intracellular distribution and function of tomato heat stress transcription factor HsfA2. Mol Cell Biol , 21, 1759-1768. 
Heidrich K., Wirthmueller L., Tasset C., Pouzet C., Deslandes L. \& Parker J.E. (2011) Arabidopsis EDS1 connects pathogen effector recognition to cell compartment-specific immune responses.Science, 334, 14011404.

Higashi Y., Ohama N., Ishikawa T., Katori T., Shimura A., Kusakabe K., Yamaguchi-Shinozaki K., Ishida J., Tanaka M., Seki M., Shinozaki K., Sakata Y., Hayashi T. \& Taji T. (2013) HsfA1d, a protein identified via FOX hunting using Thellungiella salsuginea cDNAs improves heat tolerance by regulating heat-stressresponsive gene expression. Mol Plant ,6 , 411-422.

Holmberg C.I., Hietakangas V., Mikhailov A., Rantanen J.O., Kallio M., Meinander A., Hellman J., Morrice N., MacKintosh C., Morimoto R.I., Eriksson J.E. \& Sistonen L. (2001) Phosphorylation of serine 230 promotes inducible transcriptional activity of heat shock factor 1.EMBO J, 20,3800-3810.

Hsu S.F., Lai H.C. \& Jinn T.L. (2010) Cytosol-localized heat shock factor-binding protein, AtHSBP, functions as a negative regulator of heat shock response by translocation to the nucleus and is required for seed development in Arabidopsis. Plant Physiol, 153, 773-784.

Hu Y., Mesihovic A., Jimenez-Gomez J.M., Roth S., Gebhardt P., Bublak D., Bovy A., Scharf K.D., Schleiff E. \& Fragkostefanakis S. (2020) Natural variation in HsfA2 pre-mRNA splicing is associated with changes in thermotolerance during tomato domestication. New Phytol ,225 , 1297-1310.

Huang H.-Y., Chang, K-Y., Wu, S-J. (2018) High irradiance sensitive phenotype of Arabidopsis hit2/xpo1a mutant is caused in part by nuclear confinement of AtHsfA4a. Biologia Plantarum , 62 , 69-79.

Huang Y., Li M.Y., Wang F., Xu Z.S., Huang W., Wang G.L., Ma J. \& Xiong A.S. (2015) Heat shock factors in carrot: genome-wide identification, classification, and expression profiles response to abiotic stress. Mol Biol Rep , 42 , 893-905.

Huang Y.C., Niu C.Y., Yang C.R. \& Jinn T.L. (2016) The Heat Stress Factor HSFA6b Connects ABA Signaling and ABA-Mediated Heat Responses.Plant Physiol, 172 , 1182-1199.

Hwang S.M., Kim D.W., Woo M.S., Jeong H.S., Son Y.S., Akhter S., Choi G.J. \& Bahk J.D. (2014) Functional characterization of Arabidopsis HsfA6a as a heat-shock transcription factor under high salinity and dehydration conditions. Plant Cell Environ, 37, 1202-1222.

Ihnatowicz A., Pesaresi P., Lohrig K., Wolters D., Muller B. \& Leister D. (2008) Impaired photosystem I oxidation induces STN7-dependent phosphorylation of the light-harvesting complex I protein Lhca4 in Arabidopsis thaliana. Planta, 227, 717-722.

Ihnatowicz A., Pesaresi P., Varotto C., Richly E., Schneider A., Jahns P., Salamini F. \& Leister D. (2004) Mutants for photosystem I subunit D of Arabidopsis thaliana: effects on photosynthesis, photosystem I stability and expression of nuclear genes for chloroplast functions.Plant $J, \mathbf{3 7}, 839-852$.

Ikeda M., Mitsuda N. \& Ohme-Takagi M. (2011) Arabidopsis HsfB1 and HsfB2b act as repressors of the expression of heat-inducible Hsfs but positively regulate the acquired thermotolerance. Plant Physiol ,157 , 1243-1254.

Ikeuchi M., Shibata M., Rymen B., Iwase A., Bagman A.M., Watt L., Coleman D., Favero D.S., Takahashi T., Ahnert S.E., Brady S.M. \& Sugimoto K. (2018) A Gene Regulatory Network for Cellular Reprogramming in Plant Regeneration. Plant Cell Physiol .

Jedlicka P., Mortin M.A. \& Wu C. (1997) Multiple functions of Drosophila heat shock transcription factor in vivo. $E M B O J, \mathbf{1 6}, 2452-2462$.

Jiang Y., Zheng, Q., Chen, L., LIang, Y., Wu, J. (2018) Ectopic overexpression of maize heat shock transcription factor gene $\mathrm{ZmHsf04}$ confers increased thermo and salt-stress tolerance in transgenic Arabidopsis. Acta Physiologiae Plantarum, $\mathbf{4 0}, 9$. 
Jin G.H., Gho H.J. \& Jung K.H. (2013) A systematic view of rice heat shock transcription factor family using phylogenomic analysis. J Plant Physiol, 170, 321-329.

Jung H.S., Crisp P.A., Estavillo G.M., Cole B., Hong F., Mockler T.C., Pogson B.J. \& Chory J. (2013) Subset of heat-shock transcription factors required for the early response of Arabidopsis to excess light.Proc Natl Acad Sci U S A, 110, 14474-14479.

Kang G.Y., Kim E.H., Lee H.J., Gil N.Y., Cha H.J. \& Lee Y.S. (2015) Heat shock factor 1, an inhibitor of non-homologous end joining repair. Oncotarget , 6 , 29712-29724.

Kim B.H. \& Schoffl F. (2002) Interaction between Arabidopsis heat shock transcription factor 1 and $70 \mathrm{kDa}$ heat shock proteins. J Exp Bot ,53, 371-375.

Kim G.D., Yoo S.D. \& Cho Y.H. (2018) STABILIZED1 as a heat stress-specific splicing factor in Arabidopsis thaliana. Plant Signal Behav , 13, e1432955.

Kim M.G., Kim S.Y., Kim W.Y., Mackey D. \& Lee S.Y. (2008) Responses of Arabidopsis thaliana to challenge by Pseudomonas syringae. Mol Cells, $25,323-331$.

Kollist H., Zandalinas S.I., Sengupta S., Nuhkat M., Kangasjarvi J. \& Mittler R. (2019) Rapid Responses to Abiotic Stress: Priming the Landscape for the Signal Transduction Network. Trends Plant Sci ,24, 25-37.

Kolmos E., Chow B.Y., Pruneda-Paz J.L. \& Kay S.A. (2014) HsfB2b-mediated repression of PRR7 directs abiotic stress responses of the circadian clock. Proc Natl Acad Sci U S A, 111, 16172-16177.

Kotak S., Port M., Ganguli A., Bicker F. \& von Koskull-Doring P. (2004) Characterization of C-terminal domains of Arabidopsis heat stress transcription factors (Hsfs) and identification of a new signature combination of plant class A Hsfs with AHA and NES motifs essential for activator function and intracellular localization. Plant $J, 39,98-112$.

Kotak S., Vierling E., Baumlein H. \& von Koskull-Doring P. (2007) A novel transcriptional cascade regulating expression of heat stress proteins during seed development of Arabidopsis. Plant Cell ,19 , 182-195.

Kumar M., Busch W., Birke H., Kemmerling B., Nurnberger T. \& Schoffl F. (2009) Heat shock factors HsfB1 and HsfB2b are involved in the regulation of Pdf1.2 expression and pathogen resistance in Arabidopsis.Mol Plant , 2, 152-165.

Kusano M., Tohge T., Fukushima A., Kobayashi M., Hayashi N., Otsuki H., Kondou Y., Goto H., Kawashima M., Matsuda F., Niida R., Matsui M., Saito K. \& Fernie A.R. (2011) Metabolomics reveals comprehensive reprogramming involving two independent metabolic responses of Arabidopsis to UV-B light. Plant $J, 67$ , 354-369.

Laloi C., Stachowiak M., Pers-Kamczyc E., Warzych E., Murgia I. \& Apel K. (2007) Cross-talk between singlet oxygen- and hydrogen peroxide-dependent signaling of stress responses in Arabidopsis thaliana. Proc Natl Acad Sci U S A, 104, 672-677.

Lamke J., Brzezinka K., Altmann S. \& Baurle I. (2016) A hit-and-run heat shock factor governs sustained histone methylation and transcriptional stress memory. EMBO $J, 35,162-175$.

Lang S., Liu X., Xue H., Li X. \& Wang X. (2017) Functional characterization of BnHSFA4a as a heat shock transcription factor in controlling the re-establishment of desiccation tolerance in seeds.J Exp Bot , 68 , 2361-2375.

Larkin R.M., Stefano G., Ruckle M.E., Stavoe A.K., Sinkler C.A., Brandizzi F., Malmstrom C.M. \& Osteryoung K.W. (2016) REDUCED CHLOROPLAST COVERAGE genes from Arabidopsis thaliana help to establish the size of the chloroplast compartment. Proc Natl Acad Sci U S A, 113, E1116-1125.

Lee B.H., Henderson D.A. \& Zhu J.K. (2005) The Arabidopsis cold-responsive transcriptome and its regulation by ICE1. Plant Cell , 17, 3155-3175. 
Lee J.H., Hubel A. \& Schoff F. (1995) Derepression of the activity of genetically engineered heat shock factor causes constitutive synthesis of heat shock proteins and increased thermotolerance in transgenic Arabidopsis. Plant $J, 8,603-612$.

Li F., Zhang H., Zhao H., Gao T., Song A., Jiang J., Chen F. \& Chen S. (2018) Chrysanthemum CmHSFA4 gene positively regulates salt stress tolerance in transgenic chrysanthemum. Plant Biotechnol $J, \mathbf{1 6}, 1311$ 1321.

Li G.L., Zhang H.N., Shao H., Wang G.Y., Zhang Y.Y., Zhang Y.J., Zhao L.N., Guo X.L. \& Sheteiwy M.S. (2019) ZmHsf05, a new heat shock transcription factor from Zea mays L. improves thermotolerance in Arabidopsis thaliana and rescues thermotolerance defects of the athsfa2 mutant. Plant Sci, 283, 375-384.

Li H.-C., Zhang, H-N., Li, G-L., Liu, Z-H., Zhang, Y-M., Zhang, H-M., Guo, X-L. (2015) Expression of maize heat shock transcription factor gene ZmHsf06 enhances the thermotolerance and drought-stress tolerance of transgenic Arabidopsis. Functional Plant Biology , 42, 1080-1091.

Li M., Berendzen K.W. \& Schoffl F. (2010a) Promoter specificity and interactions between early and late Arabidopsis heat shock factors. Plant Mol Biol , 73 , 559-567.

Li M., Doll J., Weckermann K., Oecking C., Berendzen K.W. \& Schoffl F. (2010b) Detection of in vivo interactions between Arabidopsis class A-HSFs, using a novel BiFC fragment, and identification of novel class B-HSF interacting proteins. Eur J Cell Biol , 89 , 126-132.

Li P.S., Yu T.F., He G.H., Chen M., Zhou Y.B., Chai S.C., Xu Z.S. \& Ma Y.Z. (2014) Genome-wide analysis of the Hsf family in soybean and functional identification of GmHsf-34 involvement in drought and heat stresses. BMC Genomics , 15, 1009.

Li X.-D., Wang, X-L., Cai, Y-M., Wu, J-H., Mo, B-T., Yu, E-R. (2017) Arabidopsis heat stress transcription factors A2 (HSFA2) and A3 (HSFA3) function in the same heat regulation pathway. Acta Physiologiae Plantarum, 39 , 39-67.

Li Y., Williams B. \& Dickman M. (2017) Arabidopsis B-cell lymphoma2 (Bcl-2)-associated athanogene 7 (BAG7)-mediated heat tolerance requires translocation, sumoylation and binding to WRKY29. New Phytol ,214, 695-705.

Li Z., Zhang L., Wang A., Xu X. \& Li J. (2013) Ectopic overexpression of SlHsfA3, a heat stress transcription factor from tomato, confers increased thermotolerance and salt hypersensitivity in germination in transgenic Arabidopsis. PLoS ONE , 8, e54880.

Licata L. \& Orchard S. (2016) The MIntAct Project and Molecular Interaction Databases. Methods Mol Biol , 1415, 55-69.

Lin K.F., Tsai M.Y., Lu C.A., Wu S.J. \& Yeh C.H. (2018) The roles of Arabidopsis HSFA2, HSFA4a, and HSFA7a in the heat shock response and cytosolic protein response. Bot Stud , 59 , 15.

Link V., Sinha A.K., Vashista P., Hofmann M.G., Proels R.K., Ehness R. \& Roitsch T. (2002) A heatactivated MAP kinase in tomato: a possible regulator of the heat stress response. FEBS Lett , 531 , 179-183.

Liu B., Hu J. \& Zhang J. (2019a) Evolutionary Divergence of Duplicated Hsf Genes in Populus. Cells , 8 .

Liu H.C. \& Charng Y.Y. (2013) Common and distinct functions of Arabidopsis class A1 and A2 heat shock factors in diverse abiotic stress responses and development. Plant Physiol , 163 , 276-290.

Liu H.C., Lamke J., Lin S.Y., Hung M.J., Liu K.M., Charng Y.Y. \& Baurle I. (2018) Distinct heat shock factors and chromatin modifications mediate the organ-autonomous transcriptional memory of heat stress.Plant $J, 95,401-413$. 
Liu H.C., Liao H.T. \& Charng Y.Y. (2011) The role of class A1 heat shock factors (HSFA1s) in response to heat and other stresses in Arabidopsis. Plant Cell Environ, 34, 738-751.

Liu H.T., Gao F., Li G.L., Han J.L., Liu D.L., Sun D.Y. \& Zhou R.G. (2008) The calmodulin-binding protein kinase 3 is part of heat-shock signal transduction in Arabidopsis thaliana. Plant $J, 55,760-773$.

Liu H.T., Li G.L., Chang H., Sun D.Y., Zhou R.G. \& Li B. (2007) Calmodulin-binding protein phosphatase PP7 is involved in thermotolerance in Arabidopsis. Plant Cell Environ , 30 , 156-164.

Liu J., Feng L., Gu X., Deng X., Qiu Q., Li Q., Zhang Y., Wang M., Deng Y., Wang E., He Y., Baurle I., Li J., Cao X. \& He Z. (2019b) An H3K27me3 demethylase-HSFA2 regulatory loop orchestrates transgenerational thermomemory in Arabidopsis. Cell Res ,29 , 379-390.

Liu J., Sun N., Liu M., Liu J., Du B., Wang X. \& Qi X. (2013) An autoregulatory loop controlling Arabidopsis HsfA2 expression: role of heat shock-induced alternative splicing. Plant Physiol ,162 , 512-521.

Locato V., Gadaleta C., De Gara L. \& De Pinto M.C. (2008) Production of reactive species and modulation of antioxidant network in response to heat shock: a critical balance for cell fate. Plant Cell Environ ,31 , 1606-1619.

Ma H., Wang, C., Yang, B., Cheng, H., Wang, Z., Mijiti, A., Ren, C., Qu, G., Zhang, H., Ma, L. (2015) CarHSFB2, a Class B Heat Shock Transcription Factor, Is Involved in Different Developmental Processes and Various Stress Responses in Chickpea (Cicer Arietinum L.).Plant Mol Biol Report , 34 , 1-14.

Meiri D. \& Breiman A. (2009) Arabidopsis ROF1 (FKBP62) modulates thermotolerance by interacting with HSP90.1 and affecting the accumulation of HsfA2-regulated sHSPs. Plant $J$, 59 , 387-399.

Miller G. \& Mittler R. (2006) Could heat shock transcription factors function as hydrogen peroxide sensors in plants? Ann Bot ,98, 279-288.

Minami A., Tominaga Y., Furuto A., Kondo M., Kawamura Y. \& Uemura M. (2015) Arabidopsis dynaminrelated protein $1 \mathrm{E}$ in sphingolipid-enriched plasma membrane domains is associated with the development of freezing tolerance. Plant $J, \mathbf{8 3}, 501-514$.

Mishra S.K., Tripp J., Winkelhaus S., Tschiersch B., Theres K., Nover L. \& Scharf K.D. (2002) In the complex family of heat stress transcription factors, HsfA1 has a unique role as master regulator of thermotolerance in tomato. Genes Dev, 16 , 1555-1567.

Mittal D., Enoki Y., Lavania D., Singh A., Sakurai H. \& Grover A. (2011) Binding affinities and interactions among different heat shock element types and heat shock factors in rice (Oryza sativa L.).FEBS $J$, 278 , 3076-3085.

Mittler R. \& Blumwald E. (2015) The roles of ROS and ABA in systemic acquired acclimation. Plant Cell , $27,64-70$.

Nagaraju M., Reddy P.S., Kumar S.A., Srivastava R.K., Kishor P.B.K. \& Rao D.M. (2015) Genome-wide Scanning and Characterization of Sorghum bicolor L. Heat Shock Transcription Factors. Current Genomics ,16, 279-291.

Navarro L., Bari R., Achard P., Lison P., Nemri A., Harberd N.P. \& Jones J.D. (2008) DELLAs control plant immune responses by modulating the balance of jasmonic acid and salicylic acid signaling. Curr Biol , $18,650-655$.

Ng G., Seabolt S., Zhang C., Salimian S., Watkins T.A. \& Lu H. (2011) Genetic dissection of salicylic acid-mediated defense signaling networks in Arabidopsis. Genetics , 189 , 851-859.

Nishizawa A., Yabuta Y., Yoshida E., Maruta T., Yoshimura K. \& Shigeoka S. (2006) Arabidopsis heat shock transcription factor A2 as a key regulator in response to several types of environmental stress. Plant $J$ , 48 , 535-547. 
Nishizawa-Yokoi A., Yoshida E., Yabuta Y. \& Shigeoka S. (2009) Analysis of the regulation of target genes by an Arabidopsis heat shock transcription factor, HsfA2. Biosci Biotechnol Biochem ,73 , 890-895.

Nover L., Scharf K.D., Gagliardi D., Vergne P., Czarnecka-Verner E. \& Gurley W.B. (1996) The Hsf world: classification and properties of plant heat stress transcription factors. Cell Stress Chaperones ,1 , 215-223.

Ochsenbein C., Przybyla D., Danon A., Landgraf F., Gobel C., Imboden A., Feussner I. \& Apel K. (2006) The role of EDS1 (enhanced disease susceptibility) during singlet oxygen-mediated stress responses of Arabidopsis. Plant $J, 47,445-456$.

Ogawa D., Yamaguchi K. \& Nishiuchi T. (2007) High-level overexpression of the Arabidopsis HsfA2 gene confers not only increased themotolerance but also salt/osmotic stress tolerance and enhanced callus growth. $J$ Exp Bot , 58 , 3373-3383.

Ohama N., Kusakabe K., Mizoi J., Zhao H., Kidokoro S., Koizumi S., Takahashi F., Ishida T., Yanagisawa S., Shinozaki K. \& Yamaguchi-Shinozaki K. (2016) The Transcriptional Cascade in the Heat Stress Response of Arabidopsis Is Strictly Regulated at the Level of Transcription Factor Expression. Plant Cell , 28 , 181-201.

Ohama N., Sato H., Shinozaki K. \& Yamaguchi-Shinozaki K. (2017) Transcriptional Regulatory Network of Plant Heat Stress Response. Trends Plant Sci, 22, 53-65.

Olate E., Jimenez-Gomez J.M., Holuigue L. \& Salinas J. (2018) NPR1 mediates a novel regulatory pathway in cold acclimation by interacting with HSFA1 factors. Nat Plants , 4, 811-823.

op den Camp R.G., Przybyla D., Ochsenbein C., Laloi C., Kim C., Danon A., Wagner D., Hideg E., Gobel C., Feussner I., Nater M. \& Apel K. (2003) Rapid induction of distinct stress responses after the release of singlet oxygen in Arabidopsis. Plant Cell , 15 , 2320-2332.

Oughtred R., Stark C., Breitkreutz B.J., Rust J., Boucher L., Chang C., Kolas N., O’Donnell L., Leung G., McAdam R., Zhang F., Dolma S., Willems A., Coulombe-Huntington J., Chatr-Aryamontri A., Dolinski K. \& Tyers M. (2019) The BioGRID interaction database: 2019 update. Nucleic Acids Res , 47, D529-D541.

Peng S. Z., Z., Zhao, K., Shi, J., Yang, Y., He, M., Wang y. (2013) A Novel Heat Shock Transcription Factor, VpHsf1, from Chinese Wild Vitis pseudoreticulata is Involved in Biotic and Abiotic Stresses. Plant Mol Biol Report, 31 , 240-247.

Perez-Salamo I., Papdi C., Rigo G., Zsigmond L., Vilela B., Lumbreras V., Nagy I., Horvath B., Domoki M., Darula Z., Medzihradszky K., Bogre L., Koncz C. \& Szabados L. (2014) The heat shock factor A4A confers salt tolerance and is regulated by oxidative stress and the mitogen-activated protein kinases MPK3 and MPK6. Plant Physiol ,165, 319-334.

Persak H. \& Pitzschke A. (2014) Dominant repression by Arabidopsis transcription factor MYB44 causes oxidative damage and hypersensitivity to abiotic stress. Int J Mol Sci , 15 , 2517-2537.

Personat J.M., Tejedor-Cano J., Prieto-Dapena P., Almoguera C. \& Jordano J. (2014) Co-overexpression of two Heat Shock Factors results in enhanced seed longevity and in synergistic effects on seedling tolerance to severe dehydration and oxidative stress. BMC Plant Biol ,14, 56 .

Peteranderl R., Rabenstein M., Shin Y.K., Liu C.W., Wemmer D.E., King D.S. \& Nelson H.C. (1999) Biochemical and biophysical characterization of the trimerization domain from the heat shock transcription factor.Biochemistry, $38,3559-3569$.

Popescu S.C., Popescu G.V., Bachan S., Zhang Z., Gerstein M., Snyder M. \& Dinesh-Kumar S.P. (2009) MAPK target networks in Arabidopsis thaliana revealed using functional protein microarrays. Genes Dev ,23, 80-92.

Port M., Tripp J., Zielinski D., Weber C., Heerklotz D., Winkelhaus S., Bublak D. \& Scharf K.D. (2004) Role of Hsp17.4-CII as coregulator and cytoplasmic retention factor of tomato heat stress transcription factor HsfA2. Plant Physiol, 135, 1457-1470. 
Prandl R., Hinderhofer K., Eggers-Schumacher G. \& Schoffl F. (1998) HSF3, a new heat shock factor from Arabidopsis thaliana, derepresses the heat shock response and confers thermotolerance when overexpressed in transgenic plants. Mol Gen Genet, 258 , 269-278.

Prieto-Dapena P., Almoguera C., Personat J.M., Merchan F. \& Jordano J. (2017) Seed-specific transcription factor HSFA9 links late embryogenesis and early photomorphogenesis. $J$ Exp Bot , 68 , 1097-1108.

Prieto-Dapena P., Castano R., Almoguera C. \& Jordano J. (2006) Improved resistance to controlled deterioration in transgenic seeds. Plant Physiol , 142, 1102-1112.

Prieto-Dapena P., Castano R., Almoguera C. \& Jordano J. (2008) The ectopic overexpression of a seedspecific transcription factor, HaHSFA9, confers tolerance to severe dehydration in vegetative organs. Plant $J$ , 54, 1004-1014.

Pucciariello C., Banti V. \& Perata P. (2012) ROS signaling as common element in low oxygen and heat stresses. Plant Physiol Biochem ,59, 3-10.

Qian J., Chen J., Liu Y.F., Yang L.L., Li W.P. \& Zhang L.M. (2014) Overexpression of Arabidopsis HsfA1a enhances diverse stress tolerance by promoting stress-induced Hsp expression. Genetics and Molecular Research, 13 , 1233-1243.

Rasmussen M.W., Roux M., Petersen M. \& Mundy J. (2012) MAP Kinase Cascades in Arabidopsis Innate Immunity. Front Plant Sci ,3 , 169.

Reddy P.S., Kavi Kishor P.B., Seiler C., Kuhlmann M., Eschen-Lippold L., Lee J., Reddy M.K. \& Sreenivasulu N. (2014) Unraveling regulation of the small heat shock proteins by the heat shock factor HvHsfB2c in barley: its implications in drought stress response and seed development. PLoS ONE , 9 , e89125.

Reindl A. \& Schoffl F. (1998) Interaction between the Arabidopsis thaliana heat shock transcription factor HSF1 and the TATA binding protein TBP. FEBS Lett , $436,318-322$.

Reindl A., Schoffl F., Schell J., Koncz C. \& Bako L. (1997) Phosphorylation by a cyclin-dependent kinase modulates DNA binding of the Arabidopsis heat-shock transcription factor HSF1 in vitro.Plant Physiol, $115,93-100$.

Renak D., Gibalova A., Solcova K. \& Honys D. (2014) A new link between stress response and nucleolar function during pollen development in Arabidopsis mediated by AtREN1 protein. Plant Cell Environ ,37 , 670-683.

Rizhsky L., Davletova S., Liang H. \& Mittler R. (2004) The zinc finger protein Zat12 is required for cytosolic ascorbate peroxidase 1 expression during oxidative stress in Arabidopsis. J Biol Chem ,279 , 11736-11743.

Ross A., Yamada K., Hiruma K., Yamashita-Yamada M., Lu X., Takano Y., Tsuda K. \& Saijo Y. (2014) The Arabidopsis PEPR pathway couples local and systemic plant immunity. EMBO J , 33,62-75.

Roth S., Mirus O., Bublak D., Scharf K.D. \& Schleiff E. (2017) DNA-binding and repressor function are prerequisites for the turnover of the tomato heat stress transcription factor HsfB1. Plant $J, 89,31-44$.

Sakuma Y., Maruyama K., Qin F., Osakabe Y., Shinozaki K. \& Yamaguchi-Shinozaki K. (2006) Dual function of an Arabidopsis transcription factor DREB2A in water-stress-responsive and heat-stress-responsive gene expression. Proc Natl Acad Sci U S A ,103 , 18822-18827.

Sakurai H. \& Enoki Y. (2010) Novel aspects of heat shock factors: DNA recognition, chromatin modulation and gene expression. FEBS $J, 277,4140-4149$.

Satyal S.H., Chen D., Fox S.G., Kramer J.M. \& Morimoto R.I. (1998) Negative regulation of the heat shock transcriptional response by HSBP1.Genes Dev , 12 , 1962-1974.

Scharf K.D., Berberich T., Ebersberger I. \& Nover L. (2012) The plant heat stress transcription factor (Hsf) family: structure, function and evolution. Biochim Biophys Acta , 1819 , 104-119. 
Scharf K.D., Heider H., Hohfeld I., Lyck R., Schmidt E. \& Nover L. (1998) The tomato Hsf system: HsfA2 needs interaction with HsfA1 for efficient nuclear import and may be localized in cytoplasmic heat stress granules. Mol Cell Biol , 18 , 2240-2251.

Schramm F., Ganguli A., Kiehlmann E., Englich G., Walch D. \& von Koskull-Doring P. (2006) The heat stress transcription factor HsfA2 serves as a regulatory amplifier of a subset of genes in the heat stress response in Arabidopsis. Plant Mol Biol , 60 , 759-772.

Schramm F., Larkindale J., Kiehlmann E., Ganguli A., Englich G., Vierling E. \& von Koskull-Doring P. (2008) A cascade of transcription factor DREB2A and heat stress transcription factor HsfA3 regulates the heat stress response of Arabidopsis. Plant J , 53 , 264-274.

Schultheiss J., Kunert O., Gase U., Scharf K.D., Nover L. \& Ruterjans H. (1996) Solution structure of the DNA-binding domain of the tomato heat-stress transcription factor HSF24. Eur J Biochem ,236 , 911-921.

Shah Z., Shah S.H., Ali G.S., Munir I., Khan R.S., Iqbal A., Ahmed N. \& Jan A. (2020) Introduction of Arabidopsis's heat shock factor HsfA1d mitigates adverse effects of heat stress on potato (Solanum tuberosum L.) plant. Cell Stress Chaperones, $25,57-63$.

Shen Z., Yao J., Sun J., Chang L., Wang S., Ding M., Qian Z., Zhang H., Zhao N., Sa G., Hou P., Lang T., Wang F., Zhao R., Shen X. \& Chen S. (2015) Populus euphratica HSF binds the promoter of WRKY1 to enhance salt tolerance. Plant Sci, 235, 89-100.

Shim D., Hwang J.U., Lee J., Lee S., Choi Y., An G., Martinoia E. \& Lee Y. (2009) Orthologs of the class A4 heat shock transcription factor HsfA4a confer cadmium tolerance in wheat and rice. Plant Cell ,21 , 4031-4043.

Shin R., Jez J.M., Basra A., Zhang B. \& Schachtman D.P. (2011) 14-3-3 proteins fine-tune plant nutrient metabolism. FEBS Lett ,585, 143-147.

Singh A., Mittal D., Lavania D., Agarwal M., Mishra R.C. \& Grover A. (2012) OsHsfA2c and OsHsfB4b are involved in the transcriptional regulation of cytoplasmic OsClpB (Hsp100) gene in rice (Oryza sativa L.). Cell Stress Chaperones , 17 , 243-254.

Song C., Lee J., Kim T., Hong J.C. \& Lim C.O. (2018) VOZ1, a transcriptional repressor of DREB2C, mediates heat stress responses in Arabidopsis. Planta, 247, 1439-1448.

Song G., Yuan S., Wen X., Xie Z., Lou L., Hu B., Cai Q. \& Xu B. (2018) Transcriptome analysis of Cdtreated switchgrass root revealed novel transcripts and the importance of HSF/HSP network in switchgrass Cd tolerance. Plant Cell Rep , 37 , 1485-1497.

Sorger P.K. \& Pelham H.R. (1988) Yeast heat shock factor is an essential DNA-binding protein that exhibits temperature-dependent phosphorylation. Cell , 54, 855-864.

Stief A., Brzezinka K., Lamke J. \& Baurle I. (2014) Epigenetic responses to heat stress at different time scales and the involvement of small RNAs. Plant Signal Behav , 9, e970430.

Su J., Zhang M., Zhang L., Sun T., Liu Y., Lukowitz W., Xu J. \& Zhang S. (2017) Regulation of Stomatal Immunity by Interdependent Functions of a Pathogen-Responsive MPK3/MPK6 Cascade and Abscisic Acid. Plant Cell , 29 , 526-542.

Sugio A., Dreos R., Aparicio F. \& Maule A.J. (2009) The cytosolic protein response as a subcomponent of the wider heat shock response in Arabidopsis. Plant Cell , 21, 642-654.

Suzuki N., Koussevitzky S., Mittler R. \& Miller G. (2012) ROS and redox signalling in the response of plants to abiotic stress. Plant Cell Environ, 35 , 259-270.

Swindell W.R., Huebner M. \& Weber A.P. (2007) Transcriptional profiling of Arabidopsis heat shock proteins and transcription factors reveals extensive overlap between heat and non-heat stress response pathways. $B M C$ 
Genomics , 8,125 .

Tanabe S., Onodera H., Hara N., Ishii-Minami N., Day B., Fujisawa Y., Hagio T., Toki S., Shibuya N., Nishizawa Y. \& Minami E. (2016) The elicitor-responsive gene for a GRAS family protein, CIGR2, suppresses cell death in rice inoculated with rice blast fungus via activation of a heat shock transcription factor, OsHsf23. Biosci Biotechnol Biochem , 80 , 145-151.

Tang D., Ade J., Frye C.A. \& Innes R.W. (2006) A mutation in the GTP hydrolysis site of Arabidopsis dynamin-related protein $1 \mathrm{E}$ confers enhanced cell death in response to powdery mildew infection. Plant $J$, $47,75-84$.

Tang M., Xu L., Wang Y., Cheng W., Luo X., Xie Y., Fan L. \& Liu L. (2019) Genome-wide characterization and evolutionary analysis of heat shock transcription factors (HSFs) to reveal their potential role under abiotic stresses in radish (Raphanus sativus L.). BMC Genomics ,20 , 772.

Tejedor-Cano J., Carranco R., Personat J.M., Prieto-Dapena P., Almoguera C., Espinosa J.M. \& Jordano J. (2014) A passive repression mechanism that hinders synergic transcriptional activation by heat shock factors involved in sunflower seed longevity. Mol Plant, 7 , 256-259.

Tejedor-Cano J., Prieto-Dapena P., Almoguera C., Carranco R., Hiratsu K., Ohme-Takagi M. \& Jordano J. (2010) Loss of function of the HSFA9 seed longevity program. Plant Cell Environ , 33 , $1408-1417$.

Tikkanen M., Gollan P.J., Suorsa M., Kangasjarvi S. \& Aro E.M. (2012) STN7 Operates in Retrograde Signaling through Controlling Redox Balance in the Electron Transfer Chain. Front Plant Sci , 3 , 277.

Trigg S.A., Garza R.M., MacWilliams A., Nery J.R., Bartlett A., Castanon R., Goubil A., Feeney J., O’Malley R., Huang S.C., Zhang Z.Z., Galli M. \& Ecker J.R. (2017) CrY2H-seq: a massively multiplexed assay for deep-coverage interactome mapping. Nat Methods , 14 , 819-825.

Tsuda K., Sato M., Glazebrook J., Cohen J.D. \& Katagiri F. (2008) Interplay between MAMP-triggered and SA-mediated defense responses.Plant $J, \mathbf{5 3}, 763-775$.

Umezawa T., Sugiyama N., Takahashi F., Anderson J.C., Ishihama Y., Peck S.C. \& Shinozaki K. (2013) Genetics and phosphoproteomics reveal a protein phosphorylation network in the abscisic acid signaling pathway in Arabidopsis thaliana. Sci Signal, 6 , rs8.

Volkov R.A., Panchuk, II, Mullineaux P.M. \& Schoffl F. (2006) Heat stress-induced H(2)O(2) is required for effective expression of heat shock genes in Arabidopsis. Plant Mol Biol , 61 , 733-746.

von Koskull-Doring P., Scharf K.D. \& Nover L. (2007) The diversity of plant heat stress transcription factors. Trends Plant Sci ,12 , 452-457.

Wang X., Huang W., Yang Z., Liu J. \& Huang B. (2016) Transcriptional regulation of heat shock proteins and ascorbate peroxidase by CtHsfA2b from African bermudagrass conferring heat tolerance in Arabidopsis.Sci Rep , 6 , 28021.

Wang X., Shi X., Chen S., Ma C. \& Xu S. (2018) Evolutionary Origin, Gradual Accumulation and Functional Divergence of Heat Shock Factor Gene Family with Plant Evolution. Front Plant Sci , 9 , 71.

Wei Y., Liu G., Chang Y., He C. \& Shi H. (2018) Heat shock transcription factor 3 regulates plant immune response through modulation of salicylic acid accumulation and signalling in cassava.Mol Plant Pathol, 19 , 2209-2220.

Williams B., Kabbage M., Britt R. \& Dickman M.B. (2010) AtBAG7, an Arabidopsis Bcl-2-associated athanogene, resides in the endoplasmic reticulum and is involved in the unfolded protein response. Proc Natl Acad Sci US A, 107, 6088-6093.

Wu Z., Liang J., Wang C., Zhao X., Zhong X., Cao X., Li G., He J. \& Yi M. (2018) Overexpression of Two Novel HsfA3s from Lily in Arabidopsis Confer Increased Thermotolerance and Salt Sensitivity via Alterations 
in Proline Catabolism. J Exp Bot, 69 , 2005-2021.

Xu P., Guo Q., Pang X., Zhang P., Kong D. \& Liu J. (2020) New Insights into Evolution of Plant Heat Shock Factors (Hsfs) and Expression Analysis of Tea Genes in Response to Abiotic Stresses. Plants (Basel) , 9 .

Xue G.P., Drenth J. \& McIntyre C.L. (2015) TaHsfA6f is a transcriptional activator that regulates a suite of heat stress protection genes in wheat (Triticum aestivum L.) including previously unknown Hsf targets. $J$ Exp Bot, 66 , 1025-1039.

Xue G.P., Sadat S., Drenth J. \& McIntyre C.L. (2014) The heat shock factor family from Triticum aestivum in response to heat and other major abiotic stresses and their role in regulation of heat shock protein genes. $J$ Exp Bot , 65 , 539-557.

Yabuta Y. (2016) Functions of heat shock transcription factors involved in response to photooxidative stresses in Arabidopsis. Biosci Biotechnol Biochem , 80 , 1254-1263.

Yamaguchi Y., Huffaker A., Bryan A.C., Tax F.E. \& Ryan C.A. (2010) PEPR2 is a second receptor for the Pep1 and Pep2 peptides and contributes to defense responses in Arabidopsis. Plant Cell ,22, 508-522.

Yamanouchi U., Yano M., Lin H., Ashikari M. \& Yamada K. (2002) A rice spotted leaf gene, Spl7, encodes a heat stress transcription factor protein. Proc Natl Acad Sci U S A, 99, 7530-7535.

Yang Z., Wang Y., Gao Y., Zhou Y., Zhang E., Hu Y., Yuan Y., Liang G. \& Xu C. (2014) Adaptive evolution and divergent expression of heat stress transcription factors in grasses. BMC Evol Biol , 14, 147.

Ye J., Yang X., Hu G., Liu Q., Li W., Zhang L. \& Song X. (2020) Genome-Wide Investigation of Heat Shock Transcription Factor Family in Wheat (Triticum aestivum L.) and Possible Roles in Anther Development.Int J Mol Sci, 21 .

Yokotani N., Ichikawa T., Kondou Y., Matsui M., Hirochika H., Iwabuchi M. \& Oda K. (2008) Expression of rice heat stress transcription factor OsHsfA2e enhances tolerance to environmental stresses in transgenic Arabidopsis. Planta, 227, 957-967.

Yoshida T., Ohama N., Nakajima J., Kidokoro S., Mizoi J., Nakashima K., Maruyama K., Kim J.M., Seki M., Todaka D., Osakabe Y., Sakuma Y., Schoffl F., Shinozaki K. \& Yamaguchi-Shinozaki K. (2011) Arabidopsis HsfA1 transcription factors function as the main positive regulators in heat shock-responsive gene expression. Mol Genet Genomics ,286 , 321-332.

Yoshida T., Sakuma Y., Todaka D., Maruyama K., Qin F., Mizoi J., Kidokoro S., Fujita Y., Shinozaki K. \& Yamaguchi-Shinozaki K. (2008) Functional analysis of an Arabidopsis heat-shock transcription factor HsfA3 in the transcriptional cascade downstream of the DREB2A stress-regulatory system. Biochem Biophys Res Commun ,368, 515-521.

Yu X.Y., Yao Y., Hong Y.H., Hou P.Y., Li C.X., Xia Z.Q., Geng M.T. \& Chen Y.H. (2019) Differential expression of the Hsf family in cassava under biotic and abiotic stresses. Genome, 62 , 563-569.

Zang D., Wang J., Zhang X., Liu Z. \& Wang Y. (2019) Arabidopsis heat shock transcription factor HSFA7b positively mediates salt stress tolerance by binding to an E-box-like motif to regulate gene expression. $J$ Exp Bot , $70,5355-5374$.

Zeng J.K., Li X., Zhang J., Ge H., Yin X.R. \& Chen K.S. (2016) Regulation of loquat fruit low temperature response and lignification involves interaction of heat shock factors and genes associated with lignin biosynthesis. Plant Cell Environ, 39 , 1780-1789.

Zhang H., Li G., Fu C., Duan S., Hu D. \& Guo X. (2020a) Genome-wide identification, transcriptome analysis and alternative splicing events of Hsf family genes in maize. Sci Rep , 10, 8073. 
Zhang L., Chen W. \& Shi B. (2020b) Genome-wide analysis and expression profiling of the heat shock transcription factor gene family in Physic Nut (Jatropha curcas L.). PeerJ , 8, e8467.

Zhang L., Li Y., Xing D. \& Gao C. (2009) Characterization of mitochondrial dynamics and subcellular localization of ROS reveal that HsfA2 alleviates oxidative damage caused by heat stress in Arabidopsis. $J$ Exp Bot , 60 , 2073-2091.

Zhang S., Wang S., Lv J., Liu Z., Wang Y., Ma N. \& Meng Q. (2018) SUMO E3 Ligase SISIZ1 Facilitates Heat Tolerance in Tomato. Plant Cell Physiol , 59 , 58-71.

Zhou J., Xu X.C., Cao J.J., Yin L.L., Xia X.J., Shi K., Zhou Y.H. \& Yu J.Q. (2018) Heat Shock Factor HsfA1a Is Essential for R Gene-Mediated Nematode Resistance and Triggers H2O2 Production(1). Plant Physiol , 176 , 2456-2471.

Zhu M.D., Zhang M., Gao D.J., Zhou K., Tang S.J., Zhou B. \& Lv Y.M. (2020) Rice OsHSFA3 Gene Improves Drought Tolerance by Modulating Polyamine Biosynthesis Depending on Abscisic Acid and ROS Levels.Int J Mol Sci, 21 .

Zhu X., Wang Y., Liu Y., Zhou W., Yan B., Yang J. \& Shen Y. (2018) Overexpression of BcHsfA1 transcription factor from Brassica campestris improved heat tolerance of transgenic tobacco. PLoS ONE ,13, e0207277.

Zipfel C., Kunze G., Chinchilla D., Caniard A., Jones J.D., Boller T. \& Felix G. (2006) Perception of the bacterial PAMP EF-Tu by the receptor EFR restricts Agrobacterium-mediated transformation. Cell ,125 , 749-760.

Zipfel C., Robatzek S., Navarro L., Oakeley E.J., Jones J.D., Felix G. \& Boller T. (2004) Bacterial disease resistance in Arabidopsis through flagellin perception. Nature, 428, 764-767.

Zou J., Guo Y., Guettouche T., Smith D.F. \& Voellmy R. (1998) Repression of heat shock transcription factor HSF1 activation by HSP90 (HSP90 complex) that forms a stress-sensitive complex with HSF1. Cell, 94, 471-480.

Table 1. Compilation of HSF interactions in different plant species. Protein-protein interactions of Arabidopsis HSFs were collected from relevant publications and internet-based databases such as BioGRID (https://thebiogrid.org), IntAct Molecular Interaction Database (https://www.ebi.ac.uk/intact/), Arabidopsis Interactions Viewer 2.0 (http://bar.utoronto.ca/interactions2/), and Arabidopsis Interactome Map (http://interactome.dfci.harvard.edu/A_thaliana/) (Arabidopsis, 2011, Dong, Lau, Song, Ierullo, Esteban, Wu, Sivieng, Nahal, Gaudinier, Pasha, Oughtred, Dolinski, Tyers, Brady, Grene, Usadel \& Provart, 2019, Licata \& Orchard, 2016, Oughtred, Stark, Breitkreutz, Rust, Boucher, Chang, Kolas, O'Donnell, Leung, McAdam, Zhang, Dolma, Willems, Coulombe-Huntington, Chatr-Aryamontri, Dolinski \& Tyers, 2019).

\begin{tabular}{|c|c|c|c|c|c|}
\hline Species & HSF protein & $\begin{array}{l}\text { Partner } \\
\text { protein }\end{array}$ & Category & Technology & Reference \\
\hline $\begin{array}{l}\text { Arabidopsis } \\
\text { thaliana }\end{array}$ & HSFA1A & $\mathrm{CDC} 2 \mathrm{a}$ & protein kinase & $\begin{array}{l}\text { pull down, } \\
\text { phosphorylation }\end{array}$ & $\begin{array}{l}\text { (Reindl, et sl., } \\
\text { 1997) }\end{array}$ \\
\hline $\begin{array}{l}\text { Arabidopsis } \\
\text { thaliana }\end{array}$ & HSFA1A & CRK1, CBK3 & protein kinase & $\begin{array}{l}\text { Y2H, FRET, } \\
\text { phosphorylation }\end{array}$ & $\begin{array}{l}\text { (Liu, et al., } \\
2008)\end{array}$ \\
\hline $\begin{array}{l}\text { Arabidopsis } \\
\text { thaliana }\end{array}$ & HSFA1A & GRF1 & 14-3-3 protein & $\mathrm{AC}-\mathrm{MS}$ & $\begin{array}{l}\text { (Shin, et al., } \\
2011 \text { ) }\end{array}$ \\
\hline $\begin{array}{l}\text { Arabidopsis } \\
\text { thaliana }\end{array}$ & HSFA1A & GRF3 & 14-3-3 protein & AC-MS & $\begin{array}{l}\text { (Shin et al., } \\
2011 \text { ) }\end{array}$ \\
\hline $\begin{array}{l}\text { Arabidopsis } \\
\text { thaliana }\end{array}$ & HSFA1A & GRF8 & $14-3-3$ protein & AC-MS & $\begin{array}{l}\text { (Shin et al., } \\
\text { 2011) }\end{array}$ \\
\hline $\begin{array}{l}\text { Arabidopsis } \\
\text { thaliana }\end{array}$ & HSFA1A & HSBP & $\begin{array}{l}\text { HSF binding } \\
\text { protein }\end{array}$ & $\mathrm{PP} 2 \mathrm{H}$ & $\begin{array}{l}\text { (Hsu, Lai \& } \\
\text { Jinn, 2010) }\end{array}$ \\
\hline
\end{tabular}




\begin{tabular}{|c|c|c|c|c|c|}
\hline Species & HSF protein & $\begin{array}{l}\text { Partner } \\
\text { protein }\end{array}$ & Category & Technology & Reference \\
\hline $\begin{array}{l}\text { Arabidopsis } \\
\text { thaliana }\end{array}$ & HSFA1A & HSFA1A & TF, HSF & $\mathrm{BiFC}, \mathrm{Y} 2 \mathrm{H}$ & $\begin{array}{l}\text { (Hsu et al., 2010, } \\
\text { Li, et al., 2010b, } \\
\text { Yoshida, et al., } \\
2011 \text { ) }\end{array}$ \\
\hline $\begin{array}{l}\text { Arabidopsis } \\
\text { thaliana }\end{array}$ & HSFA1A & HSFA1B & TF, HSF & $\begin{array}{l}\mathrm{AC}-\mathrm{W}, \mathrm{BiFC} \\
\mathrm{Y} 2 \mathrm{H}\end{array}$ & $\begin{array}{l}\text { (Hsu et al., 2010, } \\
\text { Li et al., 2010b, } \\
\text { Y oshida et al., } \\
2011 \text { ) }\end{array}$ \\
\hline $\begin{array}{l}\text { Arabidopsis } \\
\text { thaliana }\end{array}$ & HSFA1A & HSFA1D & TF, HSF & $\mathrm{BiFC}$ & $\begin{array}{l}\text { (Yoshida et } \\
\text { al., 2011) }\end{array}$ \\
\hline $\begin{array}{l}\text { Arabidopsis } \\
\text { thaliana }\end{array}$ & HSFA1A & HSFA2 & TF, HSF & $\mathrm{BiFC}, \mathrm{Y} 2 \mathrm{H}$ & $\begin{array}{l}\text { (Li, et al., } \\
\text { 2010a) }\end{array}$ \\
\hline $\begin{array}{l}\text { Arabidopsis } \\
\text { thaliana }\end{array}$ & HSFA1A & HSP70 & HSP & $\mathrm{Y} 2 \mathrm{H}$ & $\begin{array}{l}\text { (Kim \& } \\
\text { Schoffl, 2002) }\end{array}$ \\
\hline $\begin{array}{l}\text { Arabidopsis } \\
\text { thaliana }\end{array}$ & HSFA1A & HSP70-1 & HSP & $\mathrm{Y} 2 \mathrm{H}$ & $\begin{array}{l}\text { (Kim \& } \\
\text { Schoffl, 2002) }\end{array}$ \\
\hline $\begin{array}{l}\text { Arabidopsis } \\
\text { thaliana }\end{array}$ & HSFA1A & HSP90-1 & HSP & $\mathrm{BiFC}$ & $\begin{array}{l}\text { (Yoshida et } \\
\text { al., 2011) }\end{array}$ \\
\hline $\begin{array}{l}\text { Arabidopsis } \\
\text { thaliana }\end{array}$ & HSFA1A & HSP90-3 & HSP & $\mathrm{BiFC}$ & $\begin{array}{l}\text { (Yoshida et } \\
\text { al., 2011) }\end{array}$ \\
\hline $\begin{array}{l}\text { Arabidopsis } \\
\text { thaliana }\end{array}$ & HSFA1A & LCBK1 & $\begin{array}{l}\text { sphingosine } \\
\text { kinase }\end{array}$ & $\mathrm{Y} 2 \mathrm{H}$ & $\begin{array}{l}\text { (Liu et al., } \\
\text { 2008) }\end{array}$ \\
\hline $\begin{array}{l}\text { Arabidopsis } \\
\text { thaliana }\end{array}$ & HSFA1A & LCBK2 & $\begin{array}{l}\text { sphingosine } \\
\text { kinase }\end{array}$ & $\mathrm{Y} 2 \mathrm{H}$ & $\begin{array}{l}\text { (Liu et al., } \\
2008)\end{array}$ \\
\hline $\begin{array}{l}\text { Arabidopsis } \\
\text { thaliana }\end{array}$ & HSFA1A & NPR1 & $\begin{array}{l}\text { pathogen } \\
\text { defense }\end{array}$ & BiFC, Co-IP & $\begin{array}{l}\text { (Olate, et al., } \\
2018 \text { ) }\end{array}$ \\
\hline $\begin{array}{l}\text { Arabidopsis } \\
\text { thaliana }\end{array}$ & HSFA1A & PP7 & $\begin{array}{l}\text { protein } \\
\text { phosphatase }\end{array}$ & $\mathrm{Y} 2 \mathrm{H}$ & $\begin{array}{l}\text { (Liu, et al., } \\
2007)\end{array}$ \\
\hline $\begin{array}{l}\text { Arabidopsis } \\
\text { thaliana }\end{array}$ & HSFA1A & TAGK2 & protein kinase & $\mathrm{Y} 2 \mathrm{H}$ & $\begin{array}{l}\text { (Liu et al., } \\
2008)\end{array}$ \\
\hline $\begin{array}{l}\text { Arabidopsis } \\
\text { thaliana }\end{array}$ & HSFA1A & $\begin{array}{l}\text { TBP1, } \\
\text { TFIID1 }\end{array}$ & general TF & $\begin{array}{l}\text { pull down, } \\
\text { Y } 2 \mathrm{H}, \text { EMSA }\end{array}$ & $\begin{array}{l}\text { (Reindl \& } \\
\text { Schoffl, 1998) }\end{array}$ \\
\hline $\begin{array}{l}\text { Arabidopsis } \\
\text { thaliana }\end{array}$ & HSFA1A & TBP2 & general TF & $\begin{array}{l}\text { pull down, } \\
\text { EMSA }\end{array}$ & $\begin{array}{l}\text { (Czarnecka- } \\
\text { Verner, et al., } \\
\text { 2004, Reindl \& } \\
\text { Schoffl, 1998) }\end{array}$ \\
\hline $\begin{array}{l}\text { Arabidopsis } \\
\text { thaliana }\end{array}$ & HSFA1A & TFIIB & general TF & pull down & $\begin{array}{l}\text { (Czarnecka- } \\
\text { Verner et al., } \\
2004)\end{array}$ \\
\hline $\begin{array}{l}\text { Arabidopsis } \\
\text { thaliana }\end{array}$ & HSFA1B & HSBP & $\begin{array}{l}\text { HSF binding } \\
\text { protein }\end{array}$ & pull down, $\mathrm{PP} 2 \mathrm{H}$ & $\begin{array}{l}\text { (Dong, et al., } \\
\text { 2019, Hsu et al., } \\
2010 \text { ) }\end{array}$ \\
\hline $\begin{array}{l}\text { Arabidopsis } \\
\text { thaliana }\end{array}$ & HSFA1B & HSFA1B & TF, HSF & $\begin{array}{l}\mathrm{AC}-\mathrm{W}, \mathrm{BiFC}, \\
\mathrm{Y} 2 \mathrm{H}\end{array}$ & $\begin{array}{l}\text { (Hsu et al., 2010, } \\
\text { Li et al., 2010b, } \\
\text { Yoshida et al., } \\
2011 \text { ) }\end{array}$ \\
\hline $\begin{array}{l}\text { Arabidopsis } \\
\text { thaliana }\end{array}$ & HSFA1B & HSFA1D & TF, HSF & $\mathrm{BiFC}$ & $\begin{array}{l}\text { (Yoshida et } \\
\text { al., 2011) }\end{array}$ \\
\hline
\end{tabular}




\begin{tabular}{|c|c|c|c|c|c|}
\hline Species & HSF protein & $\begin{array}{l}\text { Partner } \\
\text { protein }\end{array}$ & Category & Technology & Reference \\
\hline $\begin{array}{l}\text { Arabidopsis } \\
\text { thaliana }\end{array}$ & HSFA1B & HSFA2 & TF, HSF & $\mathrm{BiFC}, \mathrm{Y} 2 \mathrm{H}$ & $\begin{array}{l}\text { (Li et al. } \\
2010 \mathrm{a})\end{array}$ \\
\hline $\begin{array}{l}\text { Arabidopsis } \\
\text { thaliana }\end{array}$ & HSFA1B & HSFA9 & TF, HSF & CrY2H-seq & $\begin{array}{l}\text { (Trigg, et al., } \\
2017 \text { ) }\end{array}$ \\
\hline $\begin{array}{l}\text { Arabidopsis } \\
\text { thaliana }\end{array}$ & HSFA1B & HSP90-1 & HSP & $\mathrm{BiFC}$ & $\begin{array}{l}\text { (Yoshida et } \\
\text { al., 2011) }\end{array}$ \\
\hline $\begin{array}{l}\text { Arabidopsis } \\
\text { thaliana }\end{array}$ & HSFA1B & HSP90-3 & HSP & $\mathrm{BiFC}$ & $\begin{array}{l}\text { (Yoshida et } \\
\text { al., 2011) }\end{array}$ \\
\hline $\begin{array}{l}\text { Arabidopsis } \\
\text { thaliana }\end{array}$ & HSFA1B & NPR1 & $\begin{array}{l}\text { pathogen } \\
\text { defense }\end{array}$ & $\mathrm{BiFC}, \mathrm{Co}-\mathrm{IP}$ & $\begin{array}{l}\text { (Olate et al., } \\
2018 \text { ) }\end{array}$ \\
\hline $\begin{array}{l}\text { Arabidopsis } \\
\text { thaliana }\end{array}$ & HSFA1D & ANNAT4 & $\begin{array}{l}\text { signaling, } \\
\text { Ca2+ }\end{array}$ & LC-MS/MS & $\begin{array}{l}\text { (Ohama, et } \\
\text { al., 2016) }\end{array}$ \\
\hline $\begin{array}{l}\text { Arabidopsis } \\
\text { thaliana }\end{array}$ & HSFA1D & ARF2 & TF, VP1-B3 & CrY2H-seq & $\begin{array}{l}\text { (Trigg et al., } \\
2017 \text { ) }\end{array}$ \\
\hline $\begin{array}{l}\text { Arabidopsis } \\
\text { thaliana }\end{array}$ & HSFA1D & AT3G19070 & TF, Homeobox & CrY2H-seq & $\begin{array}{l}\text { (Trigg et al., } \\
2017)\end{array}$ \\
\hline $\begin{array}{l}\text { Arabidopsis } \\
\text { thaliana }\end{array}$ & HSFA1D & HSFA1D & $\mathrm{TF}, \mathrm{HSF}$ & $\begin{array}{l}\text { BiFC, } \\
\text { LC-MS/MS }\end{array}$ & $\begin{array}{l}\text { (Ohama et al., } \\
\text { 2016, Yoshida et } \\
\text { al., 2011) }\end{array}$ \\
\hline $\begin{array}{l}\text { Arabidopsis } \\
\text { thaliana }\end{array}$ & HSFA1D & HSFA9 & $\mathrm{TF}, \mathrm{HSF}$ & CrY2H-seq & $\begin{array}{l}\text { (Trigg et al., } \\
2017 \text { ) }\end{array}$ \\
\hline $\begin{array}{l}\text { Arabidopsis } \\
\text { thaliana }\end{array}$ & HSFA1D & HSP70-1 & HSP & LC-MS/MS & $\begin{array}{l}\text { (Ohama et al., } \\
2016 \text { ) }\end{array}$ \\
\hline $\begin{array}{l}\text { Arabidopsis } \\
\text { thaliana }\end{array}$ & HSFA1D & HSP70-3 & HSP & LC-MS/MS & $\begin{array}{l}\text { (Ohama et al., } \\
2016 \text { ) }\end{array}$ \\
\hline $\begin{array}{l}\text { Arabidopsis } \\
\text { thaliana }\end{array}$ & HSFA1D & HSP70-4 & HSP & LC-MS/MS & $\begin{array}{l}\text { (Ohama et al., } \\
2016 \text { ) }\end{array}$ \\
\hline $\begin{array}{l}\text { Arabidopsis } \\
\text { thaliana }\end{array}$ & HSFA1D & HSP90-1 & HSP & $\mathrm{BiFC}$ & $\begin{array}{l}\text { (Yoshida et } \\
\text { al., 2011) }\end{array}$ \\
\hline $\begin{array}{l}\text { Arabidopsis } \\
\text { thaliana }\end{array}$ & HSFA1D & HSP90-3 & HSP & $\mathrm{BiFC}$ & $\begin{array}{l}\text { (Yoshida et } \\
\text { al., 2011) }\end{array}$ \\
\hline $\begin{array}{l}\text { Arabidopsis } \\
\text { thaliana }\end{array}$ & HSFA1D & MBD10 & $\begin{array}{l}\text { chromatin, DNA } \\
\text { methylation }\end{array}$ & CrY2H-seq & $\begin{array}{l}\text { (Trigg et al., } \\
2017 \text { ) }\end{array}$ \\
\hline $\begin{array}{l}\text { Arabidopsis } \\
\text { thaliana }\end{array}$ & HSFA1D & MUTE & TF, bHLH & CrY2H-seq & $\begin{array}{l}\text { (Trigg et al., } \\
2017 \text { ) }\end{array}$ \\
\hline $\begin{array}{l}\text { Arabidopsis } \\
\text { thaliana }\end{array}$ & HSFA1D & NPR1 & $\begin{array}{l}\text { pathogen } \\
\text { defense }\end{array}$ & $\mathrm{BiFC}, \mathrm{Co}-\mathrm{IP}$ & $\begin{array}{l}\text { (Olate et al., } \\
2018 \text { ) }\end{array}$ \\
\hline $\begin{array}{l}\text { Arabidopsis } \\
\text { thaliana }\end{array}$ & HSFA1D & AT5G05120 & $\mathrm{TF}, \mathrm{ZnF}$ & CrY2H-seq & $\begin{array}{l}\text { (Trigg et al., } \\
2017 \text { ) }\end{array}$ \\
\hline $\begin{array}{l}\text { Arabidopsis } \\
\text { thaliana }\end{array}$ & HSFA1E & AGL39 & $\begin{array}{l}\text { TF, } \\
\text { MADS-box }\end{array}$ & CrY2H-seq & $\begin{array}{l}\text { (Trigg et al., } \\
2017 \text { ) }\end{array}$ \\
\hline $\begin{array}{l}\text { Arabidopsis } \\
\text { thaliana }\end{array}$ & HSFA1E & ATXR5 & $\begin{array}{l}\text { chromatin } \\
\text { structure }\end{array}$ & CrY2H-seq & $\begin{array}{l}\text { (Trigg et al., } \\
2017 \text { ) }\end{array}$ \\
\hline $\begin{array}{l}\text { Arabidopsis } \\
\text { thaliana }\end{array}$ & HSFA1E & BES1 & hormone, BR & CrY2H-seq & $\begin{array}{l}\text { (Trigg et al., } \\
2017 \text { ) }\end{array}$ \\
\hline $\begin{array}{l}\text { Arabidopsis } \\
\text { thaliana }\end{array}$ & HSFA1E & BLH7 & TF, Homeobox & CrY2H-seq & $\begin{array}{l}\text { (Trigg et al., } \\
2017 \text { ) }\end{array}$ \\
\hline $\begin{array}{l}\text { Arabidopsis } \\
\text { thaliana }\end{array}$ & HSFA1E & bZIP6 & $\mathrm{TF}, \mathrm{bZIP}$ & CrY2H-seq & $\begin{array}{l}\text { (Trigg et al., } \\
2017 \text { ) }\end{array}$ \\
\hline
\end{tabular}




\begin{tabular}{|c|c|c|c|c|c|}
\hline Species & HSF protein & $\begin{array}{l}\text { Partner } \\
\text { protein }\end{array}$ & Category & Technology & Reference \\
\hline $\begin{array}{l}\text { Arabidopsis } \\
\text { thaliana }\end{array}$ & HSFA1E & COG1 & $\mathrm{TF}, \mathrm{DOF}$ & CrY2H-seq & $\begin{array}{l}\text { (Trigg et al., } \\
2017 \text { ) }\end{array}$ \\
\hline $\begin{array}{l}\text { Arabidopsis } \\
\text { thaliana }\end{array}$ & HSFA1E & LUH, MUM1 & $\begin{array}{l}\text { WD40 repeat } \\
\text { protein }\end{array}$ & CrY2H-seq & $\begin{array}{l}\text { (Trigg et al., } \\
2017 \text { ) }\end{array}$ \\
\hline $\begin{array}{l}\text { Arabidopsis } \\
\text { thaliana }\end{array}$ & HSFA1E & NGA1 & TF, RAV & CrY2H-seq & $\begin{array}{l}\text { (Trigg et al., } \\
2017 \text { ) }\end{array}$ \\
\hline $\begin{array}{l}\text { Arabidopsis } \\
\text { thaliana }\end{array}$ & HSFA1E & NPR1 & $\begin{array}{l}\text { pathogen } \\
\text { defense }\end{array}$ & BiFC, Co-IP & $\begin{array}{l}\text { (Olate et al., } \\
2018 \text { ) }\end{array}$ \\
\hline $\begin{array}{l}\text { Arabidopsis } \\
\text { thaliana }\end{array}$ & HSFA1E & PIAL2 & $\begin{array}{l}\text { protein } \\
\text { sumoylation }\end{array}$ & CrY2H-seq & $\begin{array}{l}\text { (Trigg et al., } \\
2017 \text { ) }\end{array}$ \\
\hline $\begin{array}{l}\text { Arabidopsis } \\
\text { thaliana }\end{array}$ & HSFA1E & AT3G07260 & $\begin{array}{l}\text { SMAD/FHA } \\
\text { protein }\end{array}$ & CrY2H-seq & $\begin{array}{l}\text { (Trigg et al., } \\
2017 \text { ) }\end{array}$ \\
\hline $\begin{array}{l}\text { Arabidopsis } \\
\text { thaliana }\end{array}$ & HSFA2 & AHK3 & hormone & prediction & $\begin{array}{l}\text { (Dong et al., } \\
2019 \text { ) }\end{array}$ \\
\hline $\begin{array}{l}\text { Arabidopsis } \\
\text { thaliana }\end{array}$ & HSFA2 & $\begin{array}{l}\text { FKBP62, } \\
\text { ROF1 }\end{array}$ & $\begin{array}{l}\text { HS memory, } \\
\text { tetratricopep- } \\
\text { tide repeat } \\
\text { protein }\end{array}$ & $\mathrm{BiFC}$ & $\begin{array}{l}\text { (Meiri \& } \\
\text { Breiman, } \\
\text { 2009) }\end{array}$ \\
\hline $\begin{array}{l}\text { Arabidopsis } \\
\text { thaliana }\end{array}$ & HSFA2 & HSBP & $\begin{array}{l}\text { HSF binding } \\
\text { protein }\end{array}$ & $\mathrm{PP} 2 \mathrm{H}$ & $\begin{array}{l}\text { (Hsu et al., } \\
2010)\end{array}$ \\
\hline $\begin{array}{l}\text { Arabidopsis } \\
\text { thaliana }\end{array}$ & HSFA2 & HSFA2 & TF, HSF & $\begin{array}{l}\mathrm{Y} 2 \mathrm{H}, \mathrm{BiFC}, \\
\text { cross-linking }\end{array}$ & $\begin{array}{l}\text { (Enoki \& } \\
\text { Sakurai, 2011) }\end{array}$ \\
\hline $\begin{array}{l}\text { Arabidopsis } \\
\text { thaliana }\end{array}$ & HSFA2 & HSFA3 & TF, HSF & $\mathrm{Y} 2 \mathrm{H}$ & $(\mathrm{Li}, 2017)$ \\
\hline $\begin{array}{l}\text { Arabidopsis } \\
\text { thaliana }\end{array}$ & HSFA2 & HSP90-1 & HSP & $\mathrm{BiFC}$ & $\begin{array}{l}\text { (Meiri \& } \\
\text { Breiman, } \\
\text { 2009) }\end{array}$ \\
\hline $\begin{array}{l}\text { Arabidopsis } \\
\text { thaliana }\end{array}$ & HSFA2 & MPK6 & protein kinase & pull down & $\begin{array}{l}\text { (Evrard, et al., } \\
2013 \text { ) }\end{array}$ \\
\hline $\begin{array}{l}\text { Arabidopsis } \\
\text { thaliana }\end{array}$ & HSFA2 & SUMO1 & $\begin{array}{l}\text { protein } \\
\text { sumoylation }\end{array}$ & $\mathrm{Y} 2 \mathrm{H}, \mathrm{BiFC}$ & $\begin{array}{l}\text { (Cohen-Peer, } \\
\text { et al., 2010) }\end{array}$ \\
\hline $\begin{array}{l}\text { Arabidopsis } \\
\text { thaliana }\end{array}$ & HSFA3 & $\mathrm{ADA} 2 \mathrm{~A}$ & $\begin{array}{l}\text { chromatin } \\
\text { remodeling }\end{array}$ & CrY2H-seq & $\begin{array}{l}\text { (Trigg et al., } \\
2017 \text { ) }\end{array}$ \\
\hline $\begin{array}{l}\text { Arabidopsis } \\
\text { thaliana }\end{array}$ & HSFA3 & ATO & $\begin{array}{l}\text { RNA, splicing } \\
\text { factor }\end{array}$ & CrY2H-seq & $\begin{array}{l}\text { (Trigg et al., } \\
2017 \text { ) }\end{array}$ \\
\hline $\begin{array}{l}\text { Arabidopsis } \\
\text { thaliana }\end{array}$ & HSFA3 & BIM1 & TF, bHLH & CrY2H-seq & $\begin{array}{l}\text { (Trigg et al., } \\
2017 \text { ) }\end{array}$ \\
\hline $\begin{array}{l}\text { Arabidopsis } \\
\text { thaliana }\end{array}$ & HSFA3 & BNQ3 & TF, bHLH & CrY2H-seq & $\begin{array}{l}\text { (Trigg et al., } \\
2017 \text { ) }\end{array}$ \\
\hline $\begin{array}{l}\text { Arabidopsis } \\
\text { thaliana }\end{array}$ & HSFA3 & BRM & $\begin{array}{l}\text { chromatin } \\
\text { remodeling }\end{array}$ & $\mathrm{Y} 2 \mathrm{H}$ & $\begin{array}{l}\text { (Efroni, et al., } \\
2013 \text { ) }\end{array}$ \\
\hline $\begin{array}{l}\text { Arabidopsis } \\
\text { thaliana }\end{array}$ & HSFA3 & GAL2 & $\mathrm{TF}, \mathrm{ZnF}$ & CrY2H-seq & $\begin{array}{l}\text { (Trigg et al., } \\
2017 \text { ) }\end{array}$ \\
\hline $\begin{array}{l}\text { Arabidopsis } \\
\text { thaliana }\end{array}$ & HSFA3 & HSFA6A & TF, HSF & CrY2H-seq & $\begin{array}{l}\text { (Trigg et al., } \\
2017 \text { ) }\end{array}$ \\
\hline $\begin{array}{l}\text { Arabidopsis } \\
\text { thaliana }\end{array}$ & HSFA3 & HSFA7A & TF, HSF & CrY2H-seq & $\begin{array}{l}\text { (Trigg et al., } \\
2017 \text { ) }\end{array}$ \\
\hline $\begin{array}{l}\text { Arabidopsis } \\
\text { thaliana }\end{array}$ & HSFA3 & HSFC1 & TF, HSF & CrY2H-seq & $\begin{array}{l}\text { (Trigg et al., } \\
2017 \text { ) }\end{array}$ \\
\hline
\end{tabular}




\begin{tabular}{|c|c|c|c|c|c|}
\hline Species & HSF protein & $\begin{array}{l}\text { Partner } \\
\text { protein }\end{array}$ & Category & Technology & Reference \\
\hline $\begin{array}{l}\text { Arabidopsis } \\
\text { thaliana }\end{array}$ & HSFA3 & IAA33 & $\mathrm{TF}, \mathrm{IAA}$ & CrY2H-seq & $\begin{array}{l}\text { (Trigg et al., } \\
2017 \text { ) }\end{array}$ \\
\hline $\begin{array}{l}\text { Arabidopsis } \\
\text { thaliana }\end{array}$ & HSFA3 & LSMT-L & methyltransferase & CrY2H-seq & $\begin{array}{l}\text { (Trigg et al., } \\
2017 \text { ) }\end{array}$ \\
\hline $\begin{array}{l}\text { Arabidopsis } \\
\text { thaliana }\end{array}$ & HSFA3 & NAC066 & $\mathrm{TF}, \mathrm{NAC}$ & CrY2H-seq & $\begin{array}{l}\text { (Trigg et al., } \\
2017 \text { ) }\end{array}$ \\
\hline $\begin{array}{l}\text { Arabidopsis } \\
\text { thaliana }\end{array}$ & HSFA3 & NOT9B & $\begin{array}{l}\text { translation } \\
\text { regulation }\end{array}$ & CrY2H-seq & $\begin{array}{l}\text { (Trigg et al., } \\
2017 \text { ) }\end{array}$ \\
\hline $\begin{array}{l}\text { Arabidopsis } \\
\text { thaliana }\end{array}$ & HSFA3 & OFP13 & $\begin{array}{l}\text { transcription, } \\
\text { OVATE }\end{array}$ & CrY2H-seq & $\begin{array}{l}\text { (Trigg et al., } \\
2017 \text { ) }\end{array}$ \\
\hline $\begin{array}{l}\text { Arabidopsis } \\
\text { thaliana }\end{array}$ & HSFA3 & OFP18 & $\begin{array}{l}\text { transcription, } \\
\text { OVATE }\end{array}$ & CrY2H-seq & $\begin{array}{l}\text { (Trigg et al., } \\
2017 \text { ) }\end{array}$ \\
\hline $\begin{array}{l}\text { Arabidopsis } \\
\text { thaliana }\end{array}$ & HSFA3 & S1FA2 & $\mathrm{TF}, \mathrm{S} 1 \mathrm{FA}$ & CrY2H-seq & $\begin{array}{l}\text { (Trigg et al., } \\
2017 \text { ) }\end{array}$ \\
\hline $\begin{array}{l}\text { Arabidopsis } \\
\text { thaliana }\end{array}$ & HSFA3 & SWI3B & $\begin{array}{l}\text { chromatin } \\
\text { remodeling }\end{array}$ & $\mathrm{Y} 2 \mathrm{H}$ & $\begin{array}{l}\text { (Efroni et al., } \\
2013 \text { ) }\end{array}$ \\
\hline $\begin{array}{l}\text { Arabidopsis } \\
\text { thaliana }\end{array}$ & HSFA3 & SWI3C & $\begin{array}{l}\text { chromatin } \\
\text { remodeling }\end{array}$ & $\mathrm{Y} 2 \mathrm{H}$ & $\begin{array}{l}\text { (Efroni et al., } \\
2013 \text { ) }\end{array}$ \\
\hline $\begin{array}{l}\text { Arabidopsis } \\
\text { thaliana }\end{array}$ & HSFA4A & AGL29 & $\begin{array}{l}\text { TF, } \\
\text { MADS-box }\end{array}$ & prediction & $\begin{array}{l}\text { (Dong et al., } \\
2019 \text { ) }\end{array}$ \\
\hline $\begin{array}{l}\text { Arabidopsis } \\
\text { thaliana }\end{array}$ & HSFA4A & HSFA4A & $\mathrm{TF}, \mathrm{HSF}$ & FRET, Y2H & $\begin{array}{l}\text { (Perez-Salamo, } \\
\text { et al., 2014) }\end{array}$ \\
\hline $\begin{array}{l}\text { Arabidopsis } \\
\text { thaliana }\end{array}$ & HSFA4A & HSFA4C & $\mathrm{TF}, \mathrm{HSF}$ & $\mathrm{Y} 2 \mathrm{H}$ & $\begin{array}{l}\text { (Baniwal, et } \\
\text { al., 2007), this } \\
\text { study }\end{array}$ \\
\hline $\begin{array}{l}\text { Arabidopsis } \\
\text { thaliana }\end{array}$ & HSFA4A & HSFA5 & $\mathrm{TF}, \mathrm{HSF}$ & $\mathrm{Y} 2 \mathrm{H}$ & $\begin{array}{l}\text { (Baniwal et } \\
\text { al., 2007), this } \\
\text { study }\end{array}$ \\
\hline $\begin{array}{l}\text { Arabidopsis } \\
\text { thaliana }\end{array}$ & HSFA4A & MPK3 & protein kinase & $\begin{array}{l}\text { AC-W, Y2H, } \\
\text { FRET, } \\
\text { phosphorylation }\end{array}$ & $\begin{array}{l}\text { (Perez-Salamo } \\
\text { et al., 2014) }\end{array}$ \\
\hline $\begin{array}{l}\text { Arabidopsis } \\
\text { thaliana }\end{array}$ & HSFA4A & MPK4 & protein kinase & $\begin{array}{l}\text { AC-W, protein } \\
\text { kinase }\end{array}$ & $\begin{array}{l}\text { (Andrasi, et } \\
\text { al., 2019) }\end{array}$ \\
\hline $\begin{array}{l}\text { Arabidopsis } \\
\text { thaliana }\end{array}$ & HSFA4A & MPK6 & protein kinase & $\begin{array}{l}\text { AC-W, Y2H, } \\
\text { FRET, } \\
\text { phosphorylation }\end{array}$ & $\begin{array}{l}\text { (Perez-Salamo } \\
\text { et al., 2014) }\end{array}$ \\
\hline $\begin{array}{l}\text { Arabidopsis } \\
\text { thaliana }\end{array}$ & HSFA4A & VPS55 & transport & prediction & $\begin{array}{l}\text { (Dong et al., } \\
2019 \text { ) }\end{array}$ \\
\hline $\begin{array}{l}\text { Arabidopsis } \\
\text { thaliana }\end{array}$ & HSFA4C & ARF11 & TF, VP1-B3 & CrY2H-seq & $\begin{array}{l}\text { (Trigg et al., } \\
2017 \text { ) }\end{array}$ \\
\hline $\begin{array}{l}\text { Arabidopsis } \\
\text { thaliana }\end{array}$ & HSFA4C & BHLH118 & TF, bHLH & CrY2H-seq & $\begin{array}{l}\text { (Trigg et al., } \\
2017 \text { ) }\end{array}$ \\
\hline $\begin{array}{l}\text { Arabidopsis } \\
\text { thaliana }\end{array}$ & HSFA4C & At1g35490 & TF, bZIP & CrY2H-seq & $\begin{array}{l}\text { (Trigg et al., } \\
2017 \text { ) }\end{array}$ \\
\hline $\begin{array}{l}\text { Arabidopsis } \\
\text { thaliana }\end{array}$ & HSFA4C & bZIP52 & TF, bZIP & CrY2H-seq & $\begin{array}{l}\text { (Trigg et al., } \\
2017 \text { ) }\end{array}$ \\
\hline $\begin{array}{l}\text { Arabidopsis } \\
\text { thaliana }\end{array}$ & HSFA4C & DEWAX & TF, ERF/AP2 & CrY2H-seq & $\begin{array}{l}\text { (Trigg et al., } \\
2017 \text { ) }\end{array}$ \\
\hline
\end{tabular}




\begin{tabular}{|c|c|c|c|c|c|}
\hline Species & HSF protein & $\begin{array}{l}\text { Partner } \\
\text { protein }\end{array}$ & Category & Technology & Reference \\
\hline $\begin{array}{l}\text { Arabidopsis } \\
\text { thaliana }\end{array}$ & HSFA4C & HSFA5 & TF, HSF & $\mathrm{Y} 2 \mathrm{H}$ & $\begin{array}{l}\text { (Baniwal et } \\
\text { al., 2007, Trigg } \\
\text { et al., 2017) }\end{array}$ \\
\hline $\begin{array}{l}\text { Arabidopsis } \\
\text { thaliana }\end{array}$ & HSFA4C & MYB117 & TF, MYB & CrY2H-seq & $\begin{array}{l}\text { (Trigg et al., } \\
2017 \text { ) }\end{array}$ \\
\hline $\begin{array}{l}\text { Arabidopsis } \\
\text { thaliana }\end{array}$ & HSFA4C & MYB75 & TF, MYB & CrY2H-seq & $\begin{array}{l}\text { (Trigg et al., } \\
2017 \text { ) }\end{array}$ \\
\hline $\begin{array}{l}\text { Arabidopsis } \\
\text { thaliana }\end{array}$ & HSFA4C & At5g18037 & $\mathrm{TF}, \mathrm{NAC}$ & CrY2H-seq & $\begin{array}{l}\text { (Trigg et al., } \\
2017 \text { ) }\end{array}$ \\
\hline $\begin{array}{l}\text { Arabidopsis } \\
\text { thaliana }\end{array}$ & HSFA5 & MATE & transport & prediction & $\begin{array}{l}\text { (Dong et al., } \\
2019 \text { ) }\end{array}$ \\
\hline $\begin{array}{l}\text { Arabidopsis } \\
\text { thaliana }\end{array}$ & HSFA5 & MPK4 & protein kinase & phosphorylation & $\begin{array}{l}\text { (Popescu, et } \\
\text { al., 2009) }\end{array}$ \\
\hline $\begin{array}{l}\text { Arabidopsis } \\
\text { thaliana }\end{array}$ & HSFA5 & MYB56 & TF, MYB & CrY2H-seq & $\begin{array}{l}\text { (Trigg et al., } \\
2017 \text { ) }\end{array}$ \\
\hline $\begin{array}{l}\text { Arabidopsis } \\
\text { thaliana }\end{array}$ & HSFA5 & NAC062 & $\mathrm{TF}, \mathrm{NAC}$ & CrY2H-seq & $\begin{array}{l}\text { (Trigg et al., } \\
2017 \text { ) }\end{array}$ \\
\hline $\begin{array}{l}\text { Arabidopsis } \\
\text { thaliana }\end{array}$ & HSFA6A & BRM & $\begin{array}{l}\text { chromatin } \\
\text { remodeling }\end{array}$ & $\mathrm{Y} 2 \mathrm{H}$ & $\begin{array}{l}\text { (Efroni et al., } \\
2013 \text { ) }\end{array}$ \\
\hline $\begin{array}{l}\text { Arabidopsis } \\
\text { thaliana }\end{array}$ & HSFA6A & HSFC1 & TF, HSF & CrY2H-seq & $\begin{array}{l}\text { (Trigg et al., } \\
2017 \text { ) }\end{array}$ \\
\hline $\begin{array}{l}\text { Arabidopsis } \\
\text { thaliana }\end{array}$ & HSFA6A & SWI3B & $\begin{array}{l}\text { chromatin } \\
\text { remodeling }\end{array}$ & $\mathrm{Y} 2 \mathrm{H}$ & $\begin{array}{l}\text { (Efroni et al., } \\
2013 \text { ) }\end{array}$ \\
\hline $\begin{array}{l}\text { Arabidopsis } \\
\text { thaliana }\end{array}$ & HSFA6A & SWI3C & $\begin{array}{l}\text { chromatin } \\
\text { remodeling }\end{array}$ & $\mathrm{Y} 2 \mathrm{H}$ & $\begin{array}{l}\text { (Efroni et al., } \\
2013 \text { ) }\end{array}$ \\
\hline $\begin{array}{l}\text { Arabidopsis } \\
\text { thaliana }\end{array}$ & HSFA6A & TCP4 & TF, TCP & CrY2H-seq & $\begin{array}{l}\text { (Trigg et al., } \\
2017 \text { ) }\end{array}$ \\
\hline $\begin{array}{l}\text { Arabidopsis } \\
\text { thaliana }\end{array}$ & HSFA6A & VOZ1 & $\mathrm{TF}, \mathrm{ZnF}$ & $\mathrm{Y} 2 \mathrm{H}$ & $\begin{array}{l}\text { (Hwang, et al., } \\
2014 \text { ) }\end{array}$ \\
\hline $\begin{array}{l}\text { Arabidopsis } \\
\text { thaliana }\end{array}$ & HSFA7A & At1g35490 & $\mathrm{TF}, \mathrm{bZIP}$ & CrY2H-seq & $\begin{array}{l}\text { (Trigg et al., } \\
2017 \text { ) }\end{array}$ \\
\hline $\begin{array}{l}\text { Arabidopsis } \\
\text { thaliana }\end{array}$ & HSFA7A & HSFC1 & TF, HSF & CrY2H-seq & $\begin{array}{l}\text { (Trigg et al., } \\
2017 \text { ) }\end{array}$ \\
\hline $\begin{array}{l}\text { Arabidopsis } \\
\text { thaliana }\end{array}$ & HSFA7A & NOT9B & $\begin{array}{l}\text { translation } \\
\text { control }\end{array}$ & CrY2H-seq & $\begin{array}{l}\text { (Trigg et al., } \\
2017 \text { ) }\end{array}$ \\
\hline $\begin{array}{l}\text { Arabidopsis } \\
\text { thaliana }\end{array}$ & HSFA7A & TCP2 & TF, TCP & CrY2H-seq & $\begin{array}{l}\text { (Trigg et al., } \\
2017 \text { ) }\end{array}$ \\
\hline $\begin{array}{l}\text { Arabidopsis } \\
\text { thaliana }\end{array}$ & HSFA7A & WOX13 & TF, Homeobox & CrY2H-seq & $\begin{array}{l}\text { (Trigg et al., } \\
2017 \text { ) }\end{array}$ \\
\hline $\begin{array}{l}\text { Arabidopsis } \\
\text { thaliana }\end{array}$ & HSFA8 & GRF3 & $14-3-3$ protein & AC-MS & $\begin{array}{l}\text { (Shin et al., } \\
2011 \text { ) }\end{array}$ \\
\hline $\begin{array}{l}\text { Arabidopsis } \\
\text { thaliana }\end{array}$ & HSFA8 & GRF8 & $14-3-3$ protein & AC-MS & $\begin{array}{l}\text { (Shin et al., } \\
2011 \text { ) }\end{array}$ \\
\hline $\begin{array}{l}\text { Arabidopsis } \\
\text { thaliana }\end{array}$ & HSFA8 & HSBP & $\begin{array}{l}\text { HSF binding } \\
\text { protein }\end{array}$ & prediction & $\begin{array}{l}\text { (Dong et al., } \\
2019 \text { ) }\end{array}$ \\
\hline $\begin{array}{l}\text { Arabidopsis } \\
\text { thaliana }\end{array}$ & HSFA9 & BBX9 & $\begin{array}{l}\text { TF, ZnF } \\
\text { B-Box }\end{array}$ & CrY2H-seq & $\begin{array}{l}\text { (Trigg et al., } \\
2017 \text { ) }\end{array}$ \\
\hline $\begin{array}{l}\text { Arabidopsis } \\
\text { thaliana }\end{array}$ & HSFA9 & CIB1 & TF, bHLH & CrY2H-seq & $\begin{array}{l}\text { (Trigg et al., } \\
2017 \text { ) }\end{array}$ \\
\hline
\end{tabular}




\begin{tabular}{|c|c|c|c|c|c|}
\hline Species & HSF protein & $\begin{array}{l}\text { Partner } \\
\text { protein }\end{array}$ & Category & Technology & Reference \\
\hline $\begin{array}{l}\text { Arabidopsis } \\
\text { thaliana }\end{array}$ & HSFA9 & EIL2 & TF, EIN3 & CrY2H-seq & $\begin{array}{l}\text { (Trigg et al., } \\
2017 \text { ) }\end{array}$ \\
\hline $\begin{array}{l}\text { Arabidopsis } \\
\text { thaliana }\end{array}$ & HSFA9 & ERF112 & TF, ERF/AP2 & CrY2H-seq & $\begin{array}{l}\text { (Trigg et al., } \\
2017 \text { ) }\end{array}$ \\
\hline $\begin{array}{l}\text { Arabidopsis } \\
\text { thaliana }\end{array}$ & HSFA9 & At2g02060 & TF, Homeobox & CrY2H-seq & $\begin{array}{l}\text { (Trigg et al., } \\
2017 \text { ) }\end{array}$ \\
\hline $\begin{array}{l}\text { Arabidopsis } \\
\text { thaliana }\end{array}$ & HSFA9 & MPK6 & protein kinase & phosphorylation & $\begin{array}{l}\text { (Popescu et } \\
\text { al., 2009) }\end{array}$ \\
\hline $\begin{array}{l}\text { Arabidopsis } \\
\text { thaliana }\end{array}$ & HSFA9 & NF-YC1 & TF, NFYC & CrY2H-seq & $\begin{array}{l}\text { (Trigg et al., } \\
2017 \text { ) }\end{array}$ \\
\hline $\begin{array}{l}\text { Arabidopsis } \\
\text { thaliana }\end{array}$ & HSFB1 & APG8H & $\begin{array}{l}\text { cell death, } \\
\text { autophagy }\end{array}$ & $\mathrm{Y} 2 \mathrm{H}$ & $\begin{array}{l}\text { (Li et al., } \\
2010 \mathrm{~b})\end{array}$ \\
\hline $\begin{array}{l}\text { Arabidopsis } \\
\text { thaliana }\end{array}$ & HSFB1 & ATJ3 & chaperon & $\mathrm{Y} 2 \mathrm{H}$ & $\begin{array}{l}\text { (Li et al., } \\
2010 \mathrm{~b})\end{array}$ \\
\hline $\begin{array}{l}\text { Arabidopsis } \\
\text { thaliana }\end{array}$ & HSFB1 & BHLH010 & TF, bHLH & CrY2H-seq & $\begin{array}{l}\text { (Trigg et al., } \\
2017 \text { ) }\end{array}$ \\
\hline $\begin{array}{l}\text { Arabidopsis } \\
\text { thaliana }\end{array}$ & HSFB1 & FES1 & $\mathrm{TF}, \mathrm{ZnF}$ & CrY2H-seq & $\begin{array}{l}\text { (Trigg et al., } \\
2017 \text { ) }\end{array}$ \\
\hline $\begin{array}{l}\text { Arabidopsis } \\
\text { thaliana }\end{array}$ & HSFB1 & HSFB1 & TF, HSF & $\mathrm{Y} 2 \mathrm{H}$ & $\begin{array}{l}\text { (Li et al., } \\
2010 \mathrm{~b})\end{array}$ \\
\hline $\begin{array}{l}\text { Arabidopsis } \\
\text { thaliana }\end{array}$ & HSFB1 & ORA47 & TF, ERF/AP2 & CrY2H-seq & $\begin{array}{l}\text { (Trigg et al., } \\
2017 \text { ) }\end{array}$ \\
\hline $\begin{array}{l}\text { Arabidopsis } \\
\text { thaliana }\end{array}$ & HSFB1 & PYRP2 & $\begin{array}{l}\text { enzyme, } \\
\text { plastid }\end{array}$ & $\mathrm{Y} 2 \mathrm{H}$ & $\begin{array}{l}\text { (Li et al., } \\
2010 b)\end{array}$ \\
\hline $\begin{array}{l}\text { Arabidopsis } \\
\text { thaliana }\end{array}$ & HSFB1 & TPL & $\begin{array}{l}\text { WD40 repeat } \\
\text { protein }\end{array}$ & $\mathrm{Y} 2 \mathrm{H}$ & $\begin{array}{l}\text { (Causier, et } \\
\text { al., 2012) }\end{array}$ \\
\hline $\begin{array}{l}\text { Arabidopsis } \\
\text { thaliana }\end{array}$ & HSFB1 & TPR1 & $\begin{array}{l}\text { WD } 40 \text { repeat } \\
\text { protein }\end{array}$ & $\mathrm{Y} 2 \mathrm{H}$ & $\begin{array}{l}\text { (Causier et al., } \\
2012 \text { ) }\end{array}$ \\
\hline $\begin{array}{l}\text { Arabidopsis } \\
\text { thaliana }\end{array}$ & HSFB1 & TPR2 & $\begin{array}{l}\text { WD40 repeat } \\
\text { protein }\end{array}$ & $\mathrm{Y} 2 \mathrm{H}$ & $\begin{array}{l}\text { (Causier et al., } \\
2012 \text { ) }\end{array}$ \\
\hline $\begin{array}{l}\text { Arabidopsis } \\
\text { thaliana }\end{array}$ & HSFB1 & TPR3 & $\begin{array}{l}\text { WD40 repeat } \\
\text { protein }\end{array}$ & $\mathrm{Y} 2 \mathrm{H}$ & $\begin{array}{l}\text { (Causier et al., } \\
2012 \text { ) }\end{array}$ \\
\hline $\begin{array}{l}\text { Arabidopsis } \\
\text { thaliana }\end{array}$ & HSFB1 & TPR4 & $\begin{array}{l}\text { WD40 repeat } \\
\text { protein }\end{array}$ & $\mathrm{Y} 2 \mathrm{H}$ & $\begin{array}{l}\text { (Causier et al., } \\
2012 \text { ) }\end{array}$ \\
\hline $\begin{array}{l}\text { Arabidopsis } \\
\text { thaliana }\end{array}$ & HSFB2A & TPR2 & $\begin{array}{l}\text { WD } 40 \text { repeat } \\
\text { protein }\end{array}$ & $\mathrm{Y} 2 \mathrm{H}$ & $\begin{array}{l}\text { (Causier et al., } \\
2012 \text { ) }\end{array}$ \\
\hline $\begin{array}{l}\text { Arabidopsis } \\
\text { thaliana }\end{array}$ & HSFB2A & TPR3 & $\begin{array}{l}\text { WD40 repeat } \\
\text { protein }\end{array}$ & $\mathrm{Y} 2 \mathrm{H}$ & $\begin{array}{l}\text { (Causier et al., } \\
2012 \text { ) }\end{array}$ \\
\hline $\begin{array}{l}\text { Arabidopsis } \\
\text { thaliana }\end{array}$ & HSFB2A & TPR4 & $\begin{array}{l}\text { WD40 repeat } \\
\text { protein }\end{array}$ & $\mathrm{Y} 2 \mathrm{H}$ & $\begin{array}{l}\text { (Causier et al., } \\
2012 \text { ) }\end{array}$ \\
\hline $\begin{array}{l}\text { Arabidopsis } \\
\text { thaliana }\end{array}$ & HSFB2B & FGT1 & $\begin{array}{l}\text { chromatin } \\
\text { remodeling }\end{array}$ & CrY2H-seq & $\begin{array}{l}\text { (Trigg et al., } \\
2017 \text { ) }\end{array}$ \\
\hline $\begin{array}{l}\text { Arabidopsis } \\
\text { thaliana }\end{array}$ & HSFB2B & HEMC & $\begin{array}{l}\text { enzyme, } \\
\text { plastid }\end{array}$ & $\mathrm{Y} 2 \mathrm{H}$ & $\begin{array}{l}\text { (Li et al., } \\
2010 b)\end{array}$ \\
\hline $\begin{array}{l}\text { Arabidopsis } \\
\text { thaliana }\end{array}$ & HSFB2B & HSFB2B & TF, HSF & $\mathrm{Y} 2 \mathrm{H}$ & $\begin{array}{l}\text { (Li et al., } \\
\text { 2010b) }\end{array}$ \\
\hline $\begin{array}{l}\text { Arabidopsis } \\
\text { thaliana }\end{array}$ & HSFB2B & LHCA5 & photosynthesis & $\mathrm{Y} 2 \mathrm{H}$ & $\begin{array}{l}\text { (Li et al., } \\
2010 b)\end{array}$ \\
\hline
\end{tabular}




\begin{tabular}{|c|c|c|c|c|c|}
\hline Species & HSF protein & $\begin{array}{l}\text { Partner } \\
\text { protein }\end{array}$ & Category & Technology & Reference \\
\hline $\begin{array}{l}\text { Arabidopsis } \\
\text { thaliana }\end{array}$ & HSFB2B & $\begin{array}{l}\text { MUSE14, } \\
\text { TRAF1A }\end{array}$ & $\begin{array}{l}\text { TRAF domain } \\
\text { protein }\end{array}$ & $\mathrm{Y} 2 \mathrm{H}$ & $\begin{array}{l}\text { (Li et al., } \\
\text { 2010b) }\end{array}$ \\
\hline $\begin{array}{l}\text { Arabidopsis } \\
\text { thaliana }\end{array}$ & HSFB2B & PSBP-1 & photosynthesis & $\mathrm{Y} 2 \mathrm{H}$ & $\begin{array}{l}\text { (Li et al., } \\
2010 \mathrm{~b})\end{array}$ \\
\hline $\begin{array}{l}\text { Arabidopsis } \\
\text { thaliana }\end{array}$ & HSFB2B & TPL & $\begin{array}{l}\text { WD } 40 \text { repeat } \\
\text { protein }\end{array}$ & $\mathrm{Y} 2 \mathrm{H}$ & $\begin{array}{l}\text { (Causier et al., } \\
2012 \text { ) }\end{array}$ \\
\hline $\begin{array}{l}\text { Arabidopsis } \\
\text { thaliana }\end{array}$ & HSFB2B & TPR2 & $\begin{array}{l}\text { WD40 repeat } \\
\text { protein }\end{array}$ & $\mathrm{Y} 2 \mathrm{H}$ & $\begin{array}{l}\text { (Causier et al., } \\
2012 \text { ) }\end{array}$ \\
\hline $\begin{array}{l}\text { Arabidopsis } \\
\text { thaliana }\end{array}$ & HSFB2B & TPR3 & $\begin{array}{l}\text { WD } 40 \text { repeat } \\
\text { protein }\end{array}$ & $\mathrm{Y} 2 \mathrm{H}$ & $\begin{array}{l}\text { (Causier et al., } \\
2012 \text { ) }\end{array}$ \\
\hline $\begin{array}{l}\text { Arabidopsis } \\
\text { thaliana }\end{array}$ & HSFB2B & TPR4 & $\begin{array}{l}\text { WD } 40 \text { repeat } \\
\text { protein }\end{array}$ & $\mathrm{Y} 2 \mathrm{H}$ & $\begin{array}{l}\text { (Causier et al., } \\
2012 \text { ) }\end{array}$ \\
\hline $\begin{array}{l}\text { Arabidopsis } \\
\text { thaliana }\end{array}$ & HSFB3 & AGL16 & $\begin{array}{l}\text { TF, } \\
\text { MADS-box }\end{array}$ & CrY2H-seq & $\begin{array}{l}\text { (Trigg et al., } \\
2017 \text { ) }\end{array}$ \\
\hline $\begin{array}{l}\text { Arabidopsis } \\
\text { thaliana }\end{array}$ & HSFB3 & AGL17 & $\begin{array}{l}\text { TF, } \\
\text { MADS-box }\end{array}$ & CrY2H-seq & $\begin{array}{l}\text { (Trigg et al., } \\
2017 \text { ) }\end{array}$ \\
\hline $\begin{array}{l}\text { Arabidopsis } \\
\text { thaliana }\end{array}$ & HSFB3 & ASIL2 & $\mathrm{TF}$, trihelix & CrY2H-seq & $\begin{array}{l}\text { (Trigg et al., } \\
2017 \text { ) }\end{array}$ \\
\hline $\begin{array}{l}\text { Arabidopsis } \\
\text { thaliana }\end{array}$ & HSFB3 & BHLH010 & TF, bHLH & CrY2H-seq & $\begin{array}{l}\text { (Trigg et al., } \\
2017 \text { ) }\end{array}$ \\
\hline $\begin{array}{l}\text { Arabidopsis } \\
\text { thaliana }\end{array}$ & HSFB3 & CIA2 & $\mathrm{TF}, \mathrm{CCT}$ & CrY2H-seq & $\begin{array}{l}\text { (Trigg et al., } \\
2017 \text { ) }\end{array}$ \\
\hline $\begin{array}{l}\text { Arabidopsis } \\
\text { thaliana }\end{array}$ & HSFB3 & EMB1967 & RNA binding & CrY2H-seq & $\begin{array}{l}\text { (Trigg et al., } \\
2017 \text { ) }\end{array}$ \\
\hline $\begin{array}{l}\text { Arabidopsis } \\
\text { thaliana }\end{array}$ & HSFB3 & ENAP1 & $\mathrm{TF}$, trihelix & CrY2H-seq & $\begin{array}{l}\text { (Trigg et al., } \\
2017 \text { ) }\end{array}$ \\
\hline $\begin{array}{l}\text { Arabidopsis } \\
\text { thaliana }\end{array}$ & HSFB3 & GT3A & TF, Homeobox & CrY2H-seq & $\begin{array}{l}\text { (Trigg et al., } \\
2017 \text { ) }\end{array}$ \\
\hline $\begin{array}{l}\text { Arabidopsis } \\
\text { thaliana }\end{array}$ & HSFB3 & HB21 & $\begin{array}{l}\text { TF, ZnF- } \\
\text { Homeobox }\end{array}$ & CrY2H-seq & $\begin{array}{l}\text { (Trigg et al., } \\
2017 \text { ) }\end{array}$ \\
\hline $\begin{array}{l}\text { Arabidopsis } \\
\text { thaliana }\end{array}$ & HSFB3 & HB30 & $\begin{array}{l}\text { TF, ZnF- } \\
\text { Homeobox }\end{array}$ & CrY2H-seq & $\begin{array}{l}\text { (Trigg et al., } \\
2017 \text { ) }\end{array}$ \\
\hline $\begin{array}{l}\text { Arabidopsis } \\
\text { thaliana }\end{array}$ & HSFB3 & At4g03250 & TF, Homeobox & CrY2H-seq & $\begin{array}{l}\text { (Trigg et al., } \\
2017 \text { ) }\end{array}$ \\
\hline $\begin{array}{l}\text { Arabidopsis } \\
\text { thaliana }\end{array}$ & HSFB3 & NOT9B & $\begin{array}{l}\text { translation } \\
\text { control }\end{array}$ & CrY2H-seq & $\begin{array}{l}\text { (Trigg et al., } \\
2017 \text { ) }\end{array}$ \\
\hline $\begin{array}{l}\text { Arabidopsis } \\
\text { thaliana }\end{array}$ & HSFB3 & PTF1 & TF, TCP & CrY2H-seq & $\begin{array}{l}\text { (Trigg et al., } \\
2017 \text { ) }\end{array}$ \\
\hline $\begin{array}{l}\text { Arabidopsis } \\
\text { thaliana }\end{array}$ & HSFB3 & RAP2.5 & TF, ERF/AP2 & CrY2H-seq & $\begin{array}{l}\text { (Trigg et al., } \\
2017 \text { ) }\end{array}$ \\
\hline $\begin{array}{l}\text { Arabidopsis } \\
\text { thaliana }\end{array}$ & HSFB3 & REN1 & TF, HSF & CrY2H-seq & $\begin{array}{l}\text { (Trigg et al., } \\
2017 \text { ) }\end{array}$ \\
\hline $\begin{array}{l}\text { Arabidopsis } \\
\text { thaliana }\end{array}$ & HSFB3 & AT3G43430 & $\begin{array}{l}\text { RING/U-box } \\
\text { protein }\end{array}$ & CrY2H-seq & $\begin{array}{l}\text { (Trigg et al., } \\
2017 \text { ) }\end{array}$ \\
\hline $\begin{array}{l}\text { Arabidopsis } \\
\text { thaliana }\end{array}$ & HSFB3 & TCP10 & $\mathrm{TF}, \mathrm{TCP}$ & CrY2H-seq & $\begin{array}{l}\text { (Trigg et al., } \\
2017 \text { ) }\end{array}$ \\
\hline $\begin{array}{l}\text { Arabidopsis } \\
\text { thaliana }\end{array}$ & HSFB3 & TCP14 & TF, TCP & CrY2H-seq & $\begin{array}{l}\text { (Trigg et al., } \\
2017 \text { ) }\end{array}$ \\
\hline
\end{tabular}




\begin{tabular}{|c|c|c|c|c|c|}
\hline Species & HSF protein & $\begin{array}{l}\text { Partner } \\
\text { protein }\end{array}$ & Category & Technology & Reference \\
\hline $\begin{array}{l}\text { Arabidopsis } \\
\text { thaliana }\end{array}$ & HSFB3 & TCP4 & TF, TCP & CrY2H-seq & $\begin{array}{l}\text { (Trigg et al., } \\
2017 \text { ) }\end{array}$ \\
\hline $\begin{array}{l}\text { Arabidopsis } \\
\text { thaliana }\end{array}$ & HSFB3 & ТCP9 & $\mathrm{TF}, \mathrm{TCP}$ & CrY2H-seq & $\begin{array}{l}\text { (Trigg et al., } \\
2017 \text { ) }\end{array}$ \\
\hline $\begin{array}{l}\text { Arabidopsis } \\
\text { thaliana }\end{array}$ & HSFB3 & WOX13 & TF, Homeobox & CrY2H-seq & $\begin{array}{l}\text { (Trigg et al., } \\
2017 \text { ) }\end{array}$ \\
\hline $\begin{array}{l}\text { Arabidopsis } \\
\text { thaliana }\end{array}$ & HSFC1 & $\mathrm{ADA} 2 \mathrm{~A}$ & $\begin{array}{l}\text { chromatin } \\
\text { remodeling }\end{array}$ & CrY2H-seq & $\begin{array}{l}\text { (Trigg et al., } \\
2017 \text { ) }\end{array}$ \\
\hline $\begin{array}{l}\text { Arabidopsis } \\
\text { thaliana }\end{array}$ & HSFC1 & $\mathrm{AMC1}$ & $\begin{array}{l}\text { cell death, } \\
\text { metacaspase }\end{array}$ & CrY2H-seq & $\begin{array}{l}\text { (Trigg et al., } \\
2017 \text { ) }\end{array}$ \\
\hline $\begin{array}{l}\text { Arabidopsis } \\
\text { thaliana }\end{array}$ & HSFC1 & ARIA & hormone, ABA & CrY2H-seq & $\begin{array}{l}\text { (Trigg et al., } \\
2017 \text { ) }\end{array}$ \\
\hline $\begin{array}{l}\text { Arabidopsis } \\
\text { thaliana }\end{array}$ & HSFC1 & BRC1 & TF, TCP & CrY2H-seq & $\begin{array}{l}\text { (Trigg et al., } \\
2017 \text { ) }\end{array}$ \\
\hline $\begin{array}{l}\text { Arabidopsis } \\
\text { thaliana }\end{array}$ & HSFC1 & At1g19980 & cytomatrix & $\mathrm{Y} 2 \mathrm{H}$ & $\begin{array}{l}\text { (Arabidopsis, } \\
2011 \text { ) }\end{array}$ \\
\hline $\begin{array}{l}\text { Arabidopsis } \\
\text { thaliana }\end{array}$ & HSFC1 & FIT1 & TF, bHLH & CrY2H-seq & $\begin{array}{l}\text { (Trigg et al., } \\
2017 \text { ) }\end{array}$ \\
\hline $\begin{array}{l}\text { Arabidopsis } \\
\text { thaliana }\end{array}$ & HSFC1 & HB30 & $\begin{array}{l}\mathrm{TF}, \mathrm{ZnF}- \\
\text { Homeobox }\end{array}$ & CrY2H-seq & $\begin{array}{l}\text { (Trigg et al., } \\
2017 \text { ) }\end{array}$ \\
\hline $\begin{array}{l}\text { Arabidopsis } \\
\text { thaliana }\end{array}$ & HSFC1 & MBD6 & $\begin{array}{l}\text { chromatin } \\
\text { structure, } \\
\text { DNA } \\
\text { methylation }\end{array}$ & CrY2H-seq & $\begin{array}{l}\text { (Trigg et al., } \\
2017 \text { ) }\end{array}$ \\
\hline $\begin{array}{l}\text { Arabidopsis } \\
\text { thaliana }\end{array}$ & HSFC1 & NF-YB7 & TF, NFYB & CrY2H-seq & $\begin{array}{l}\text { (Trigg et al., } \\
2017 \text { ) }\end{array}$ \\
\hline $\begin{array}{l}\text { Arabidopsis } \\
\text { thaliana }\end{array}$ & HSFC1 & PBL35 & protein kinase & $\mathrm{Y} 2 \mathrm{H}$ & $\begin{array}{l}\text { (Arabidopsis, } \\
2011 \text { ) }\end{array}$ \\
\hline $\begin{array}{l}\text { Arabidopsis } \\
\text { thaliana }\end{array}$ & HSFC1 & At2g27930 & TF, PLATZ & CrY2H-seq & $\begin{array}{l}\text { (Trigg et al., } \\
2017 \text { ) }\end{array}$ \\
\hline $\begin{array}{l}\text { Arabidopsis } \\
\text { thaliana }\end{array}$ & HSFC1 & PTF1 & $\mathrm{TF}, \mathrm{TCP}$ & CrY2H-seq & $\begin{array}{l}\text { (Trigg et al., } \\
2017 \text { ) }\end{array}$ \\
\hline $\begin{array}{l}\text { Arabidopsis } \\
\text { thaliana }\end{array}$ & HSFC1 & TCP10 & $\mathrm{TF}, \mathrm{TCP}$ & CrY2H-seq & $\begin{array}{l}\text { (Trigg et al., } \\
2017 \text { ) }\end{array}$ \\
\hline $\begin{array}{l}\text { Arabidopsis } \\
\text { thaliana }\end{array}$ & HSFC1 & TCP14 & TF, TCP & CrY2H-seq & $\begin{array}{l}\text { (Trigg et al., } \\
2017 \text { ) }\end{array}$ \\
\hline $\begin{array}{l}\text { Arabidopsis } \\
\text { thaliana }\end{array}$ & HSFC1 & TCP4 & TF, TCP & CrY2H-seq & $\begin{array}{l}\text { (Trigg et al., } \\
2017 \text { ) }\end{array}$ \\
\hline $\begin{array}{l}\text { Arabidopsis } \\
\text { thaliana }\end{array}$ & HSFC1 & TGA9, & TF, bZIP & CrY2H-seq & $\begin{array}{l}\text { (Trigg et al., } \\
2017 \text { ) }\end{array}$ \\
\hline $\begin{array}{l}\text { Arabidopsis } \\
\text { thaliana }\end{array}$ & HSFC1 & AT2G47850 & $\mathrm{TF}, \mathrm{ZnF}$ & CrY2H-seq & $\begin{array}{l}\text { (Trigg et al., } \\
2017 \text { ) }\end{array}$ \\
\hline $\begin{array}{l}\text { Eriobotrya } \\
\text { japonica }\end{array}$ & HSF3 & AP2-1 & TF, ERF/AP2 & $\mathrm{Y} 2 \mathrm{H}, \mathrm{BiFC}$ & $\begin{array}{l}\text { (Zeng, et al., } \\
2016)\end{array}$ \\
\hline Glycine max & HSFB1 & TFIIB & General TF & pull down & $\begin{array}{l}\text { (Czarnecka- } \\
\text { Verner et al., } \\
2004)\end{array}$ \\
\hline $\begin{array}{l}\text { Helianthus } \\
\text { annuus }\end{array}$ & HSFA4A & HSFA9 & TF, HSF & $\mathrm{Y} 2 \mathrm{H}, \mathrm{BiFC}$ & $\begin{array}{l}\text { (Tejedor-Cano, } \\
\text { et al., 2014) }\end{array}$ \\
\hline
\end{tabular}




\begin{tabular}{|c|c|c|c|c|c|}
\hline Species & HSF protein & $\begin{array}{l}\text { Partner } \\
\text { protein }\end{array}$ & Category & Technology & Reference \\
\hline $\begin{array}{l}\text { Helianthus } \\
\text { annuus }\end{array}$ & HSFA4A & IAA27 & $\begin{array}{l}\text { Aux/IAA } \\
\text { protein }\end{array}$ & $\mathrm{BiFC}$ & $\begin{array}{l}\text { (Tejedor-Cano } \\
\text { et al., 2014) }\end{array}$ \\
\hline $\begin{array}{l}\text { Lilium } \\
\text { longiflorum }\end{array}$ & HSFA1 & HSFA2 & TF, $\mathrm{HSF}$ & $\mathrm{Y} 2 \mathrm{H}, \mathrm{BiFC}$ & $\begin{array}{l}\text { (Gong, et al., } \\
2014 \text { ) }\end{array}$ \\
\hline $\begin{array}{l}\text { Lycopersicon } \\
\text { peruvianum }\end{array}$ & HSFA1 & HSFA2 & TF, HSF & Y2H, Co-IP & $\begin{array}{l}\text { Chan- } \\
\text { Schaminet, et } \\
\text { al., 2009, Port, } \\
\text { et al., 2004, } \\
\text { Scharf, et al., } \\
\text { 1998) }\end{array}$ \\
\hline $\begin{array}{l}\text { Lycopersicon } \\
\text { peruvianum }\end{array}$ & HSFA1 & HSFB1 & TF, HSF & $\begin{array}{l}\text { pull-down, } \\
\text { EMSA }\end{array}$ & $\begin{array}{l}\text { (Bharti, et al., } \\
2004)\end{array}$ \\
\hline $\begin{array}{l}\text { Lycopersicon } \\
\text { peruvianum }\end{array}$ & HSFB1 & $\mathrm{HAC} 1 / \mathrm{CBP}$ & $\begin{array}{l}\text { chromatin } \\
\text { structure }\end{array}$ & $\begin{array}{l}\text { pull-down, } \\
\text { EMSA }\end{array}$ & $\begin{array}{l}\text { (Bharti et al., } \\
2004)\end{array}$ \\
\hline Oryza sativa & HSFA2c & HSFA2c & $\mathrm{TF}, \mathrm{HSF}$ & $\begin{array}{l}\text { cross-link, } \\
\text { BiFC }\end{array}$ & $\begin{array}{l}\text { (Mittal, et al., } \\
2011 \text { ) }\end{array}$ \\
\hline Oryza sativa & HSFA7 & ClpB-cyt & HSP & $\mathrm{Y} 2 \mathrm{H}, \mathrm{BiFC}$ & $\begin{array}{l}\text { (Singh, et al., } \\
2012)\end{array}$ \\
\hline Oryza sativa & HSFA9 & HSFA9 & TF, HSF & $\begin{array}{l}\text { cross-link, } \\
\text { BiFC }\end{array}$ & $\begin{array}{l}\text { (Mittal et al., } \\
\text { 2011) }\end{array}$ \\
\hline Oryza sativa & HsfB4b & ClpB-cyt & HSP & $\mathrm{Y} 2 \mathrm{H}, \mathrm{BiFC}$ & $\begin{array}{l}\text { (Singh et al., } \\
2012)\end{array}$ \\
\hline Oryza sativa & HsfB4b & HSF26 & TF, HSF & $\mathrm{Y} 2 \mathrm{H}$ & $\begin{array}{l}\text { (Mittal et al., } \\
\text { 2011) }\end{array}$ \\
\hline Oryza sativa & HsfB4b & HSFA2a & TF, HSF & $\mathrm{Y} 2 \mathrm{H}$ & $\begin{array}{l}\text { (Mittal et al., } \\
\text { 2011) }\end{array}$ \\
\hline Oryza sativa & HsfB4b & HSFA7 & $\mathrm{TF}, \mathrm{HSF}$ & $\mathrm{Y} 2 \mathrm{H}$ & $\begin{array}{l}\text { (Mittal et al., } \\
\text { 2011, Singh et } \\
\text { al., 2012) }\end{array}$ \\
\hline Oryza sativa & HsfB4b & HSFB4b & TF, HSF & $\begin{array}{l}\text { cross-link, } \\
\text { BiFC }\end{array}$ & $\begin{array}{l}\text { (Mittal et al., } \\
\text { 2011) }\end{array}$ \\
\hline Oryza sativa & HsfB4b & $\mathrm{HSFB} 4 \mathrm{c}$ & TF, HSF & $\mathrm{Y} 2 \mathrm{H}$ & $\begin{array}{l}\text { (Mittal et al., } \\
2011 \text { ) }\end{array}$ \\
\hline $\begin{array}{l}\text { Solanum } \\
\text { lycopersicum }\end{array}$ & HsfA1 & $\mathrm{HAC} 1 / \mathrm{CBP}$ & $\begin{array}{l}\text { chromatin } \\
\text { structure }\end{array}$ & $\begin{array}{l}\text { pull-down, } \\
\text { EMSA }\end{array}$ & $\begin{array}{l}\text { (Bharti et al., } \\
2004)\end{array}$ \\
\hline $\begin{array}{l}\text { Solanum } \\
\text { lycopersicum }\end{array}$ & HsfA1 & SlSIZ1 & Sumoylation & $\mathrm{Y} 2 \mathrm{H}, \mathrm{BiFC}$ & $\begin{array}{l}\text { (Zhang, et al., } \\
2018 \text { ) }\end{array}$ \\
\hline $\begin{array}{l}\text { Solanum } \\
\text { lycopersicum }\end{array}$ & HSFA1a & HSP70 & HSP & $\mathrm{Y} 2 \mathrm{H}$ & $\begin{array}{l}\text { (Hahn, et al., } \\
2011)\end{array}$ \\
\hline $\begin{array}{l}\text { Solanum } \\
\text { lycopersicum }\end{array}$ & HSFA1a & HSP90 & HSP & $\mathrm{Y} 2 \mathrm{H}$ & $\begin{array}{l}\text { (Hahn et al., } \\
2011)\end{array}$ \\
\hline $\begin{array}{l}\text { Solanum } \\
\text { lycopersicum }\end{array}$ & HSFA2 & Hsp17.4-CII & HSP, small & $\begin{array}{l}\mathrm{Y} 2 \mathrm{H} \text {, complex } \\
\text { form }\end{array}$ & $\begin{array}{l}\text { (Port et al., } \\
2004)\end{array}$ \\
\hline $\begin{array}{l}\text { Solanum } \\
\text { lycopersicum }\end{array}$ & HSFA2 & HSP70 & HSP & $\mathrm{Y} 2 \mathrm{H}$ & $\begin{array}{l}\text { (Hahn et al., } \\
2011)\end{array}$ \\
\hline $\begin{array}{l}\text { Solanum } \\
\text { lycopersicum }\end{array}$ & HSFA2 & HSP90 & HSP & $\mathrm{Y} 2 \mathrm{H}$ & $\begin{array}{l}\text { (Hahn et al., } \\
\text { 2011) }\end{array}$ \\
\hline $\begin{array}{l}\text { Solanum } \\
\text { lycopersicum }\end{array}$ & HSFA4b & HSFA5 & TF, HSF & $\begin{array}{l}\text { Y2H, BiFC, } \\
\text { pull-down }\end{array}$ & $\begin{array}{l}\text { (Baniwal et } \\
\text { al., 2007) }\end{array}$ \\
\hline
\end{tabular}




\begin{tabular}{|c|c|c|c|c|c|}
\hline Species & HSF protein & $\begin{array}{l}\text { Partner } \\
\text { protein }\end{array}$ & Category & Technology & Reference \\
\hline $\begin{array}{l}\text { Solanum } \\
\text { lycopersicum }\end{array}$ & HsfB1 & HSP70 & $\mathrm{HSP}$ & $\mathrm{Y} 2 \mathrm{H}$ & $\begin{array}{l}\text { (Hahn et al., } \\
2011)\end{array}$ \\
\hline $\begin{array}{l}\text { Solanum } \\
\text { lycopersicum }\end{array}$ & HsfB1 & HSP90 & HSP & $\mathrm{Y} 2 \mathrm{H}$ & $\begin{array}{l}\text { (Hahn et al., } \\
\text { 2011, Roth, et } \\
\text { al., 2017) }\end{array}$ \\
\hline $\begin{array}{l}\text { Thellungiella } \\
\text { salsuginea, } \\
\text { Arabidopsis } \\
\text { thaliana }\end{array}$ & HsfA1d & HSP90-1 & HSP & $\mathrm{BiFC}$ & $\begin{array}{l}\text { (Higashi, et } \\
\text { al., 2013) }\end{array}$ \\
\hline $\begin{array}{l}\text { Thellungiella } \\
\text { salsuginea, } \\
\text { Arabidopsis } \\
\text { thaliana }\end{array}$ & HsfA1d & HSP90-3 & HSP & $\mathrm{BiFC}$ & $\begin{array}{l}\text { (Higashi et al., } \\
2013 \text { ) }\end{array}$ \\
\hline Zea mays & HSFA2c & HSBP2 & $\begin{array}{l}\text { HSF binding } \\
\text { protein }\end{array}$ & $\mathrm{Y} 2 \mathrm{H}$ & $\begin{array}{l}\text { (Fu, et al., } \\
2006)\end{array}$ \\
\hline Zea mays & HSFA2e & HSBP1, EMP2 & $\begin{array}{l}\text { HSF binding } \\
\text { protein }\end{array}$ & $\mathrm{Y} 2 \mathrm{H}$ & $\begin{array}{l}\text { (Fu et al., } \\
2006)\end{array}$ \\
\hline Zea mays & HSFA3 & HSBP1, EMP2 & $\begin{array}{l}\text { HSF binding } \\
\text { protein }\end{array}$ & $\mathrm{Y} 2 \mathrm{H}$ & $\begin{array}{l}\text { (Fu et al., } \\
2006)\end{array}$ \\
\hline Zea mays & HSFA4a & HSBP2 & $\begin{array}{l}\text { HSF binding } \\
\text { protein }\end{array}$ & $\mathrm{Y} 2 \mathrm{H}$ & $\begin{array}{l}\text { (Fu et al., } \\
2006)\end{array}$ \\
\hline Zea mays & HSFA4d & HSBP1, EMP2 & $\begin{array}{l}\text { HSF binding } \\
\text { protein }\end{array}$ & $\mathrm{Y} 2 \mathrm{H}$ & $\begin{array}{l}\text { (Fu et al., } \\
2006)\end{array}$ \\
\hline Zea mays & HSFA5 & HSBP1, EMP2 & $\begin{array}{l}\text { HSF binding } \\
\text { protein }\end{array}$ & $\mathrm{Y} 2 \mathrm{H}$ & $\begin{array}{l}\text { (Fu et al., } \\
2006)\end{array}$ \\
\hline
\end{tabular}

Table 2. Identification of HSFA4A interacting proteins. Two weeks-old transgenic Arabidopsis plants, expressing the HSFA4A-YFP fusion under the control of pHSFA4A promoter were treated with or without 150 $\mathrm{mM} \mathrm{NaCl}$ for 6 hours prior protein extraction. Two independent lines were used in each experiment, which were repeated three times. Proteins co-purified with HSFA4A-YFP were identified by mass spectrometry. Numbers show averages of 6 samples (Peptide count, Coverage \%).

\begin{tabular}{|c|c|c|c|c|c|}
\hline & & & & Control & Control \\
\hline Gene & AGI & location & Protein Name & Peptide Count & Coverage $\%$ \\
\hline HSFA4A & AT4G18880 & nucleus & HSFA4A & 103.0 & 68.2 \\
\hline HSFA5 & AT4G13980 & nucleus & HSFA5 & 13.3 & 23.4 \\
\hline HSFA4C & AT5G45710 & nucleus & HSFA4C & 3.7 & 3.0 \\
\hline PRP8 & AT1G80070 & nucleus & Pre-mRNA-processing-splicing factor 8 & 4.3 & 2.8 \\
\hline TIM-barrel & AT5G66420 & cytosol & TIM-barrel signal transduction protein & 4.0 & 7.1 \\
\hline EDR3 & AT3G60190 & cytosol & Enhanced disease resistance 3 & 3.2 & 6.4 \\
\hline REC1 & AT1G01320 & nucleus & Reduced chloroplast coverage 1 & 3.7 & 4.5 \\
\hline BAG7 & AT5G62390 & ER, nucleus & BAG family molecular chaperone regulator 7 & 6.5 & 13.6 \\
\hline HOP2 & AT1G62740 & nucleus & Hsp70-Hsp90 organizing protein 2 & 6.5 & 14.1 \\
\hline HON4 & AT3G18035 & nucleus & A linker histone like protein & 10.3 & 14.4 \\
\hline
\end{tabular}

\section{FIGURES}


Figure 1. Growth and survival of wild type (Col-0) and HSFA4A overexpressing Arabidopsis plants (HSFox1, HSFox2 lines) exposed to salt or combination of salt and heat stress. 10 days-old in vitro germinated plantlets were transferred to medium containing $100 \mathrm{mM} \mathrm{NaCl}$ and treated with high temperature $\left(37^{\circ} \mathrm{C}\right)$ for 4 days. Plantlets were subsequently transferred to standard growth medium for 10 days for recovery (Andrasi et al. , 2019). Note, that HSFA4A overexpressing plants were less affected and survived at higher rates after salt and the combined stresses. Growth and survival of plants was similar on control plates or after heat stress only (not shown).

Figure 2. Developmental regulation of HSF genes in Arabidopsis thaliana . Transcript data were compiled from Genevestigator database (https://genevestigator.com). A) Transcript levels in different developmental stages. Darker color indicates higher transcript levels. Each value is average of hundreds of microarrayderived expression data. B) Change in transcript levels during germination. In color codes red and green indicates up or downregulation, respectively.

Figure 3. Effect of abiotic stress treatments on the expression of Arabidopsis HSF genes, compiled from Genevestigator. Treatments are indicated in the left side while genotypes including wild type ecotypes and mutants are listed in the right side of the color boxes. Red and green boxes indicate up or downregulation, respectively.

Figure 4. HSF expression in plants infected with pathogens, treated with elicitors or oxidative agents and in defense or redox-related mutants. Data were compiled from Genevestigator. Red and green indicates up or downregulation, respectively.

Figure 5. HSFA4A in abiotic and biotic stress regulatory networks. Expression of HSFA4A is induced by a number of extreme environmental conditions and by various pathogens. ROS is generated during stress, which, with other signals can enhance HSFA4Aexpression (Perez-Salamo et al. , 2014). Transcript data suggest that microbial EF-Tu, Pep2 and FLG22 signals are mediated by the receptor kinases PEPR1, PEPR2, and the PCD-regulating EDS4. According to a DAP-seq study (Bartlett, O'Malley, Huang, Galli, Nery, Gallavotti \& Ecker, 2017), HSF, ZAT, HB, MYB and WRKY TFs can bind to the HSFA 4 A promoter (Andrasi et al. , 2019). HSFA4A can interact with various proteins (see: Table 1, 2). MPK3, MPK4 and MPK6 phosphorylate HSFA4A, which promotes multimerisation (Andrasi et al. , 2019, Perez-Salamo et al. , 2014). ROS, in particular $\mathrm{H}_{2} \mathrm{O}_{2}$ can stabilize trimers (Perez-Salamoet al. , 2014). HSFA4A can form heteromers with HSFA4C and HSFA5, which can repress HSFA4A (Baniwal et al. , 2007). HSFA4A can activate a number of target genes, which encode protective proteins or other TFs such as ZAT12 or WRKY30 (Davletova et al. , 2005, Perez-Salamo et al. , 2014). These TFs can induce another set of target genes (Rizhsky, Davletova, Liang \& Mittler, 2004). Green and red lines or arrows indicate positive and negative regulation, respectively.

\section{Supplemental data}

Table S1. Functional diversity of plant HSF genes. List of publications reporting stress-related phenotypes of HSF mutants or transgenic overexpressing plants.

Table S2. Transcript levels of 21 HSF genes in 34 ecotypes of Arabidopsis thaliana.

Table S3: Transcript profiles of Arabidopsis heat shock genes in response to abiotic stress conditions.

Table S4: Transcript profiles of Arabidopsis heat shock genes in response to pathogens and elicitors.

\section{Supplemental Methods}

Identification of HSFA4A-interacting proteins by coimmunprecipitation and mass spectrometry. 
$\mathrm{NaCl}$

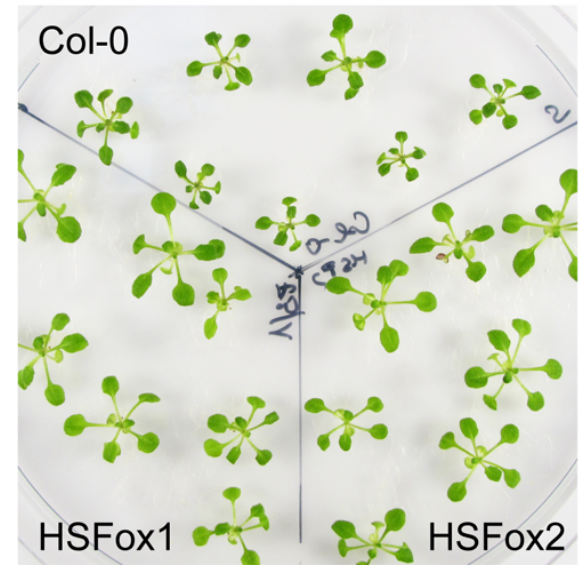

$\mathrm{NaCl}+37^{\circ} \mathrm{C}$

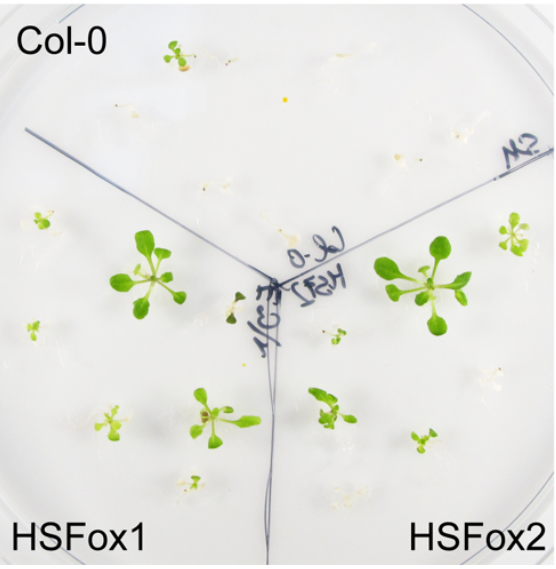

A

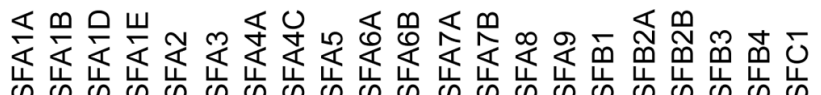

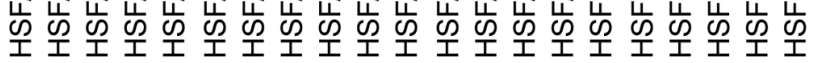

\section{Germinated seed Seedling Young rosette Developed rosette Bolting Young flower Developed flower Flowers and siliques Mature siliques Senescence}
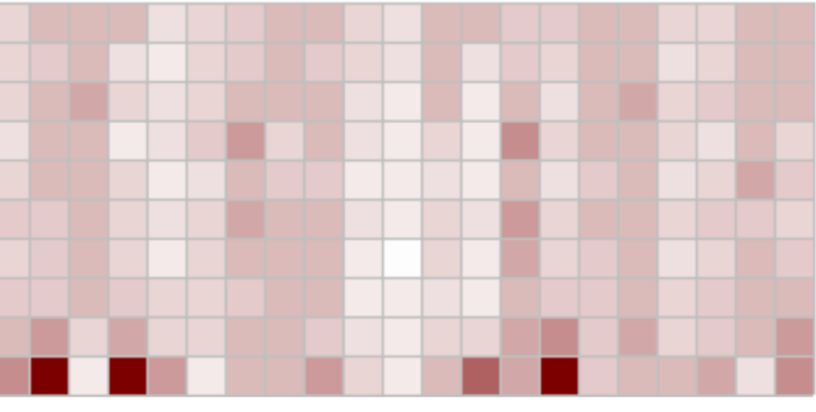

Expression

$100 \%$

B

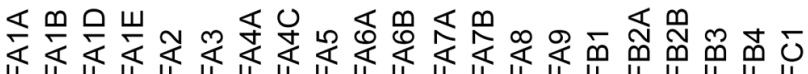

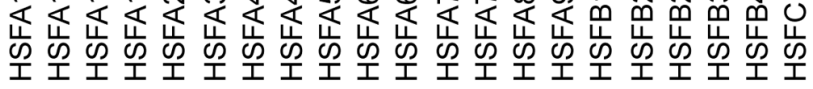

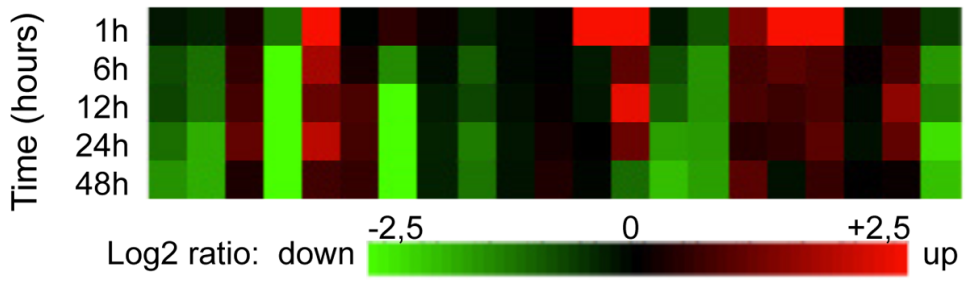




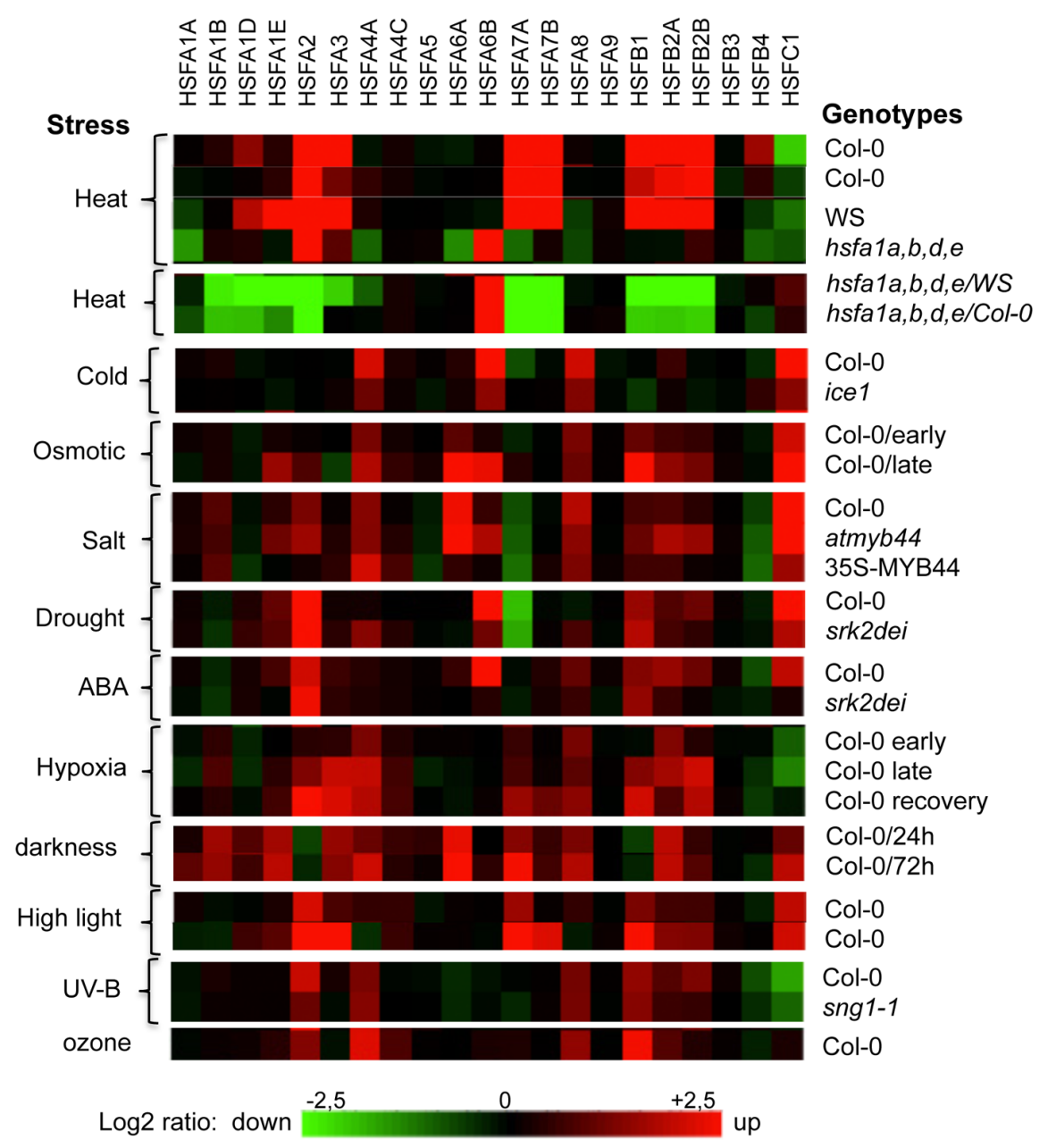




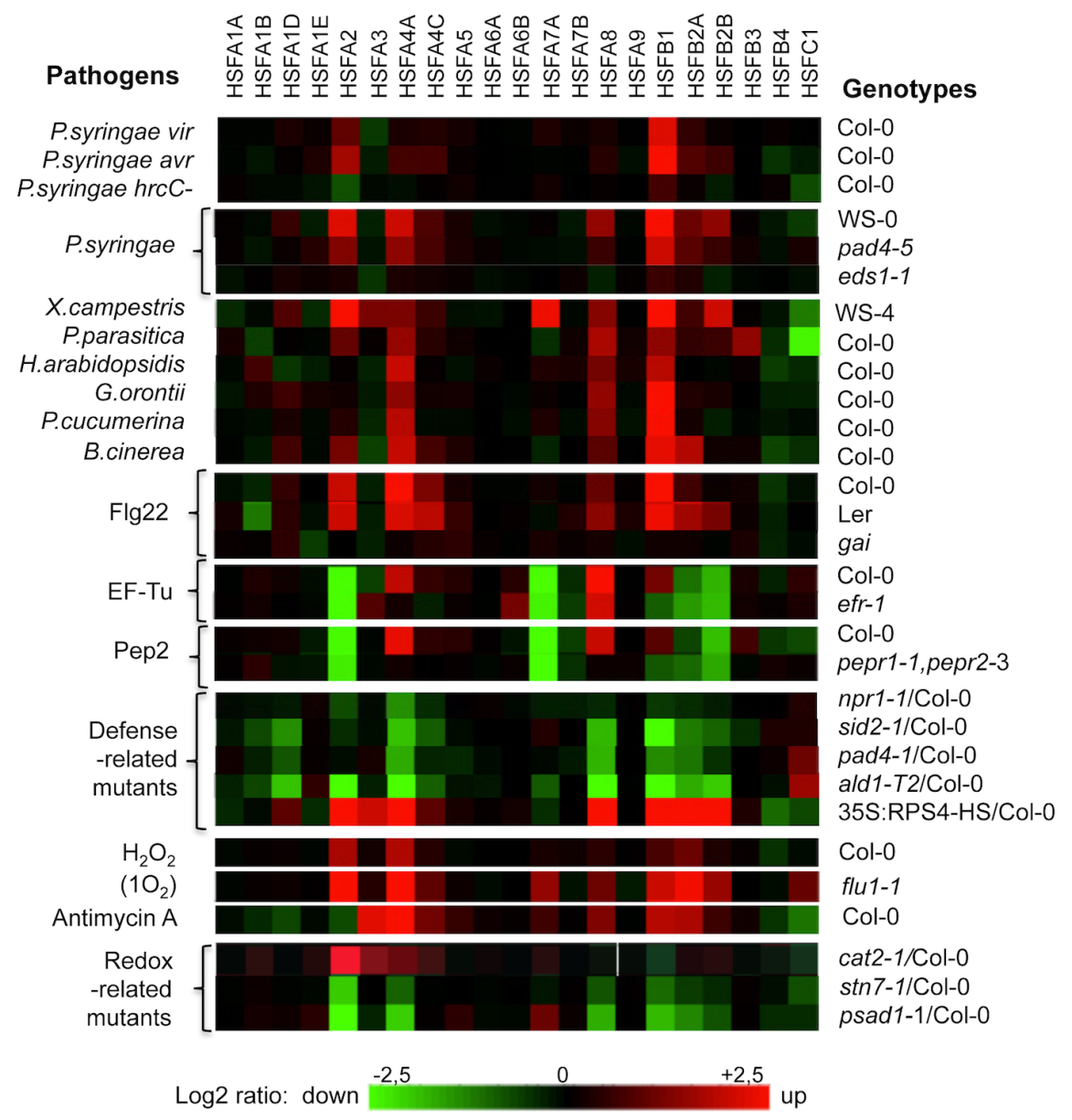




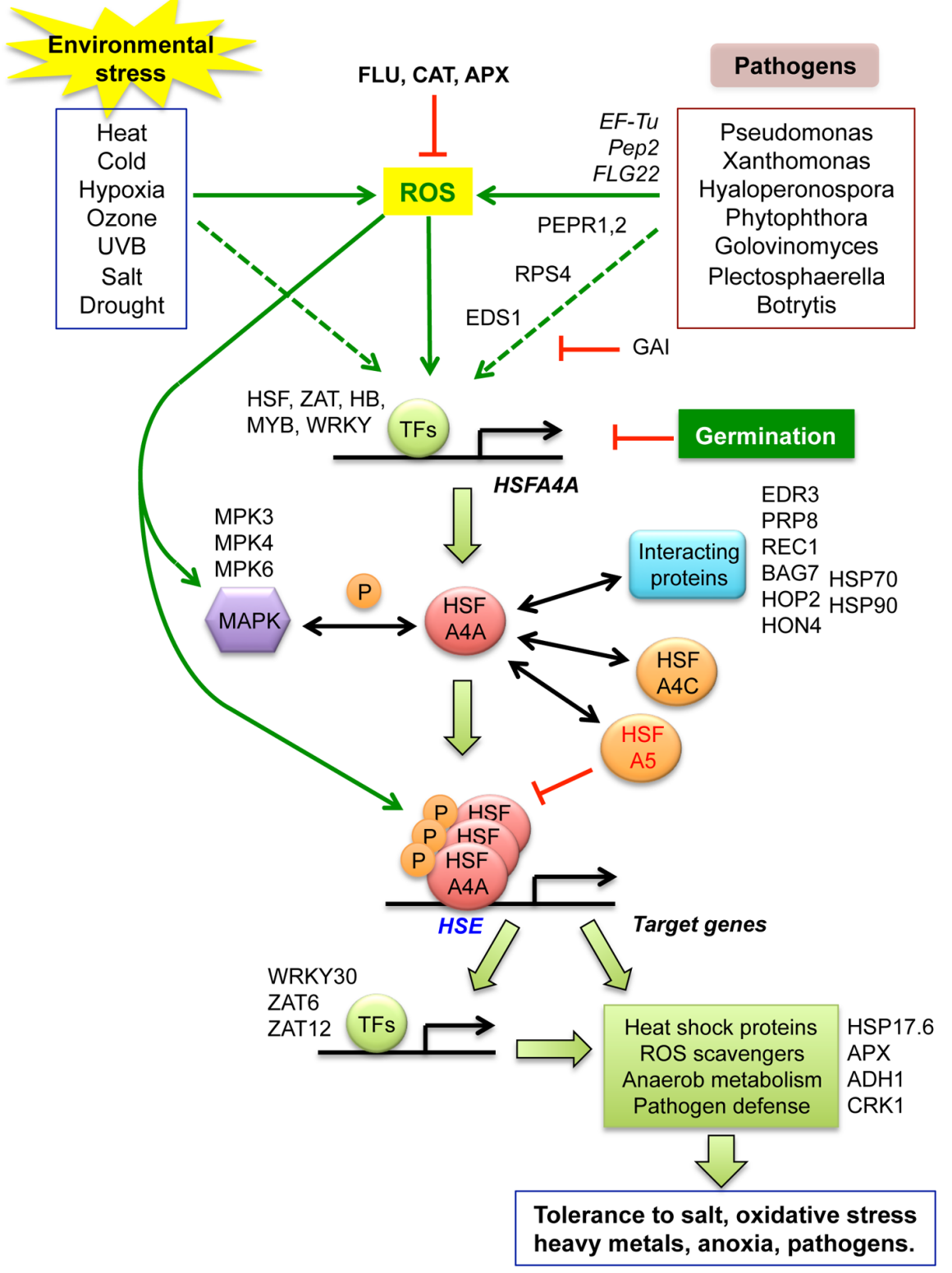

